\title{
A STEP CLOSER: ECONOMIC INTEGRATION AND THE AFRICAN CONTINENTAL FREE TRADE AREA
}

\author{
NSONGURUA J. UDOMBANA*
}

Post-colonial Africa views economic integration as an endogenous means for attaining self-reliant, sustainable development. Working under various regional and sub-regional economic institutions, states elaborated several norms in search of legitimacy in economic competence. However, several political and economic pathogens, including weak institutions, have blighted those efforts. This paper interrogates the African Continental Free Trade Area (AfCFTA or CFTA), which is the latest attempt to reboot the integration drive and achieve sustainable development. The CFTA seeks to create a geographic zone where goods and services will move freely among member states by removing trade distortions and boosting factor mobility, competition, and investment. After a rigorous analysis of the relevant normative instruments and examining the vertical and horizontal relationship between the CFTA and regional economic communities (RECs)/member states, the paper articulates some objective criteria for measuring the CFTA's effectiveness. It concludes that, if faithfully implemented, the CFTA could maximize utility and increase welfare. For the analysis and conclusions, the paper deploys principles of public international law as well as economic theories, with a blend of political and moral philosophy.

Copyright (C) 2020 Nsongurua J. Udombana

* 2020: LL.M. (Lagos), LL.D. (UNISA); of the Nigerian Bar; Professor of Public International Law, Babcock University, Nigeria; Pro-Chancellor, Ritman University, Nigeria (2015-2019). Nsongurua Udombana writes and publishes globally on international law themes, with an Afrocentric outlook. His works are accessible at SSRN Author page: <http://ssrn.com/author=1162030>; ResearchGate page: $<$ https://www.researchgate.net/profile/Nsongurua_Udombana $>$. He may be reached at $<$ udombanan@babcock.edu.ng>, or <udombanan@gmail.com>. I express my gratitude to Konyinsola Ajayi and Cheluchi Onyemelukwe for their comments on the initial draft of this paper. I also thank the editors of the Duke Journal of Comparative and International Law for their serial interventions that made this paper more readable than it otherwise would have been. Any remaining error is mine. 
I. IN LIEU OF AN INTRODUCTION 3

II. AFRICA'S QUEST FOR AN ENDOGENOUS DEVELOPMENT

PARADIGM 10

A. Note on Economic Integration ...................................................... 12

1. The Concept of Integration ....................................................... 12

2. The Potential Benefits of Integration ............................................ 13

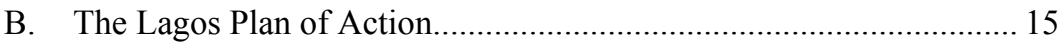

1. The Rhetoric of Self-Reliance ................................................... 16

2. The Destructive Force of Uncensored Neo-liberalism................... 18

C. The African Economic Community (AEC) Treaty ............................ 22

1. The AEC Objectives and Principles .......................................... 23

2. Modalities for Establishing the AEC …........................................ 23

3. A Convoluted Relationship between the AEC and the OAU....... 25

D. The AU Act Preserves the AEC Treaty............................................... 26

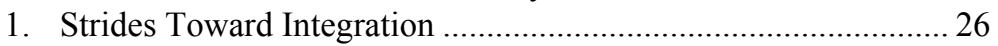

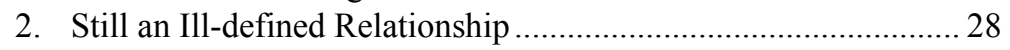

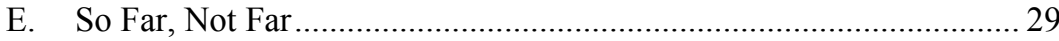

III. TOWARDS A NEW DEVELOPMENT PARADIGM: THE AFCFTA AGREEMENT ….................................................................................... 33

A. Purpose and Scope ….................................................................. 35

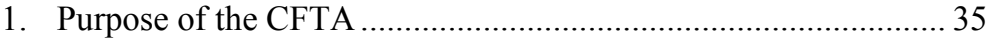

2. The Scope of Application .......................................................... 40

B. Shared Values and Organizing Principles .............................................. 44

1. A Liberalized Market................................................................ 45

2. Non-Discrimination ................................................................. 48

3. Factor Mobility ....................................................................... 51

4. Special and Differential Treatment (SDT) .................................. 54

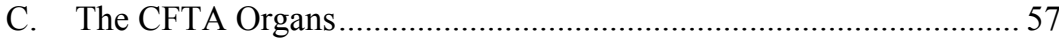

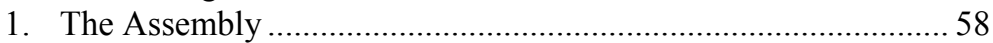

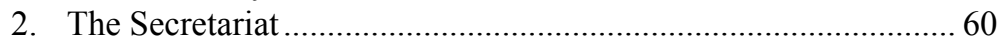

IV. VERTICAL AND HORIZONTAL RELATIONSHIPS ................................ 63

A. The Continental Free Trade Area and Regional Economic

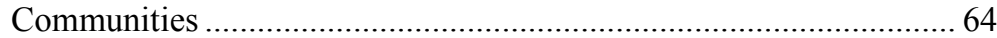

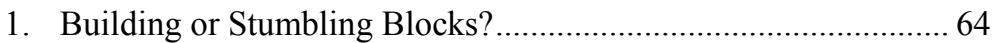

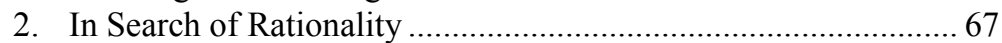

B. The Continental Free Trade Area and Member States ...................... 70

1. Regional Order and Limitation of Sovereign Rights .................. 70

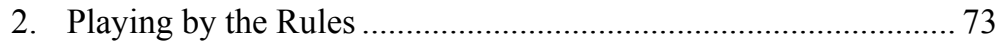

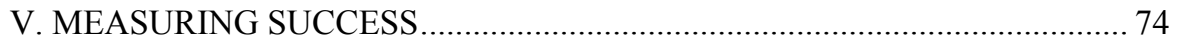

A. Towards a Robust Intra-African Trade ……........................................ 75

1. Addressing Factor Mobility ....................................................... 76

2. Effective Domestic Institutions Underpinned by the Rule of

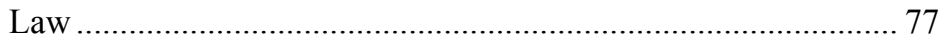

3. Adding Value to Africa's Primary Products ................................ 79

4. Capacitating Africa's Small and Medium Enterprises.................. 81 
B. Competitiveness in Global Trade 82

C. Sustainable Prosperity and Peace ................................................... 85

VI. CONCLUSION: A STEP CLOSER 87

"The task ahead is great indeed, heavy is the responsibility; and yet it is a noble and glorious challenge. A challenge which calls for the courage to believe, the courage to dare, the courage to do, the courage to fight, the courage to achieve."

\section{IN LIEU OF AN INTRODUCTION}

The establishment and full operationalization of the African Continental Free Trade Area (AfCFTA or CFTA) will be the culmination of Africa's long quest for economic integration. Post-independence states and generations of Pan-Africanists have always recognized the necessity for cooperation in the economic, social, and cultural fields. ${ }^{2}$ The Organization of African Unity (OAU) was founded in 1963 to provide a platform for such cooperation among the newly independent states. ${ }^{3}$ At the summits leading to its founding, President Kwame Nkrumah of Ghana, then the leading PanAfricanist, urged states to combine their economies into sub-regional markets and ultimately create one African Common Market (ACM). He also called for a political union based on a common foreign and monetary policy, defense, citizenship, currency, and an African Central Bank (ACB). His logic was that there can be no economic integration and freedom without a political union. ${ }^{4}$ Many of Africa's moderate leaders did not accept Nkrumah's federalist and radical ideas. From the menu of Pan-African proposals tabled by the federalists, collective Africa only managed to establish an African Development Bank (ADB) in 1963 to finance economic and social development in the continent. ${ }^{5}$

1. H.E. Moussa Faki Mahamat, Chairperson, Afr. Union Comm'n, Address at the Handover Ceremony of AfCFTA Buildings to African Union (AU) (Aug. 17, 2020) [hereinafter Statement by Mahamat] (quoting Kwame Nkrumah, Former Ghana Prime Minister, Address to the National Assembly (June 12, 1965)).

2. See Peter J. Schraeder, African Politics and Society: A Mosaic in Transformation 253 (2d ed. 2004) (noting the consensus among early African leaders that pan-Africanism constituted a worthy foreign policy goal).

3. See Charter of the Organization of African Unity, art. 2(2), May 25, 1963, 479 U.N.T.S. 39 (entered into force Sept. 13, 1963).

4. Cf. Kwame Nkrumah, Africa Must Unite 163 (1963) (discussing the need to create a common currency and pool African cash crops to attain a better commanding position in the market and use united selling policies to get better prices and resist undercutting tactics of buyers).

5. See Agreement Establishing the African Development Bank, art. 1, Aug. 4, 1963, 510 U.N.T.S. 3. 
The creation of the East African Community (EAC) in $1966^{6}$ was perhaps one of "the most far-reaching of early integration attempts in Africa."7 The idea of a CFTA also gestated in the 1970s. In 1973, the OAU Assembly of Heads of States and Governments ("OAU Assembly") adopted the Declaration on African Cooperation, Development and Economic Independence. ${ }^{8}$ The Declaration set out the basic principles for collective or individual actions by states in several areas, including transport and communications, infrastructure, industrialization, and monetary and trade cooperation. ${ }^{9}$ Three years after, the OAU Council of Ministers adopted the Kinshasa Declaration calling for the establishment of an African Economic Community (AEC) within a period of 15 to 25 years. ${ }^{10}$ The OAU took a giant step towards realizing this aspiration when it adopted the Lagos Plan of Action (LPA) and Final Act in $1980,{ }^{11}$ and the AEC Treaty in $1991 .{ }^{12}$ But no sooner had the AEC Treaty entered into force in 1994 than the integration project went into hibernation. States failed to meet agreed timelines, besides the lack of political will in fulfilling other treaty obligations. ${ }^{13}$ It took a refurbished regional organization to rejig Africa's integration and

6. Treaty for the Establishment of the East African Community, May 5, 1966, 5 I.L.M. 633. A Revised EAC Treaty was adopted in Arusha, Tanzania on Nov. 30, 1999. Treaty for the Establishment of the East African Community, art. 27(1), Nov. 30, 1999, 2144 U.N.T.S. 257 [hereinafter Revised EAC Treaty].

7. U.N. ECON. COMM'N FOR AFR., ASSESSING REGIONAL INTEGRATION IN AFRICA, at 28, U.N. Sales No. E.04.II.K.3 (2004) [hereinafter UNECA, ASSESSING REGIONAL INTEGRATION] ("The community... reflects Africa's desire to transform itself from a continent of predominantly least developed and developing economies into a strong united bloc of nations . ...").

8. African Declaration on Cooperation, Development and Economic Independence, Assembly of the Heads of State and Government, Tenth Ordinary Session, CM/ST.12(XXI) (May 25, 1973), https://archives.au.int/bitstream/handle/123456789/5947/African\%20Declaration\%20on\%20Cooperatio $\mathrm{n} \%$ 20Development\%20and\%20Economic\%20Independence_E.pdf?sequence=1\&isAllowed=y. The Declaration followed the recommendation of the African Ministerial Conference on Trade, Development and Monetary Problems held in Abidjan from May 9 to 13, 1973. Id. at 1.

9. See Stephen Karangizi, The Regional Economic Communities, in THE AFrICAN UnION: LEGAL AND INSTITUTIONAL FRAMEWORK 233-34 (Abdulqawi A. Yusuf \& Fatsah Ouguergou eds., 2012) (citing Strategy and Approach to the Implementation of the African Economic Community Treaty, AEC Economic and Social Commission, First Session, AEC/ECOSOC3(1)Rev.1 (June 6, 1996)).

10. See id.

11. Org. of African Unity [OAU], Lagos Plan of Action for the Economic Development of Africa 1980-2000 (Apr. 1980) [hereinafter LPA], https://www.nepad.org/publication/lagos-plan-of-action.

12. Treaty Establishing the African Economic Community, adopted June 3, 1991, 30 I.L.M. 1245 [hereinafter AEC Treaty] (entered into force May 12, 1994).

13. See generally Gino J. Naldi \& Konstantinos D. Magliveras, The African Economic Community: Emancipation for African States or Yet Another Glorious Failure, 24 N.C. J. INT'L L. \& COM. REG. 601, 602 (1999) (analyzing the AEC's chances of success before concluding significant reforms are necessary for the AEC to succeed); Kwaku Danso, The African Economic Community: Problems and Prospects, 42 AFR. TODAY 31, 31 (1995) (evaluating the AEC and the challenges of African continental integration through a common market). 
development vision. The African Union (AU), established in $2000^{14}$ and inaugurated in 2002, replaced the OAU as Africa's inter-governmental institution for political, security, and economic governance. ${ }^{15}$

The AU Assembly of Heads of State and Government ("AU Assembly") Decision on Boosting Intra-African Trade and Fast Tracking the CFTA of $2012^{16}$ was, perhaps, the most direct step towards actualizing the integration vision post the AU's inauguration. The Assembly reiterated that promoting intra-African trade is fundamental to "sustainable economic development, employment generation and effective integration of Africa into the global economy."17 It endorsed "the Framework, Road Map and Architecture for Fast Tracking the establishment of the [CFTA] and the Action Plan for Boosting Intra-African Trade" and urged the High Level African Trade Committee (HATC) to "provide a facilitating role and unlock any blockages that might arise."18 Three years later, the Assembly inaugurated the AfCFTA negotiations to integrate Africa's markets in line with the objectives and principles enunciated in the AEC Treaty. ${ }^{19}$ Although Africa missed the indicative date of 2017 initially set for the

14. See Constitutive Act of the African Union, art. 2, adopted July 11, 2000, 2158 U.N.T.S. 3 [hereinafter AU Act] (entered into force May 26, 2001).

15. For some of the emerging literature on the AU, see generally NSONGURUA J. UDOMBANA, THE AFricAn Union in InTERnAtional LAW: SElected Studies (2020) [hereinafter Udombana, The AFRICAN UNION] (examining the development and multiple functions of the AU); OLUFEMI AMAO, AFriCAN Union LAW: THE EMERGENCE OF A SUi GENERIS LEgal Order (2018) (exploring the impact of the AU on the existing legal order in Africa); THE AFrICAN UNION: AUTOCRACY, DiPLOMACY AND PEACEBUilding IN AFRICA (Tony Karbo \& Tim Murithi eds., 2018) (describing the AU's new development framework and the challenges to pan-African integration); SANDIPANI DASH, REGIONAL RESURGENCE IN AFRICA: ProsPeCtS AND CHALlENGES OF AFriCAN UNION (2017) (analyzing the AU's mandate and the organization's relationship to the African member countries); THE AFRICAN UNION: LEGAL AND INSTITUTIONAL FRAMEWORK, supra note 9 (detailing the organizational structure, operations, and objectives of the AU); DIEDRE L. BADEJO, THE AFRICAN UNION (2008) (illustrating the development of the AU and the future of the organization); A UNITED STATES OF AFRICA? (Eddy Maloka ed., 2001) (discussing the AU's foundations and what steps African countries must take to ensure the AU's long-term survival); Nsongurua J. Udombana, The Institutional Structure of the African Union: A Legal Analysis, 33 CAL. W. INT'L L.J. 69 (2002) (offering a detailed scrutiny of the AU's structure, legal status, and relationship to member states).

16. See Decision on Boosting Intra-African Trade and Fast Tracking the Continental Free Trade Area, Assembly of the Union, Eighteenth Ordinary Session, Assembly/AU/Dec.394(XVIII) (Jan. 29, 2012) [hereinafter Decision on Boosting Intra-African Trade], https://au.int/sites/default/files/ decisions/9649-assembly_au_dec_391_-_415_xviii_e.pdf.

17. Id. para. 2 .

18. Id. para. 3 .

19. See Decision on the Launch of Continental Free Trade Area Negotiations, para. 3, Assembly of the Union, Twenty-Fifth Ordinary Session, Assembly/AU/Dec.569(XXV) (June 14, 2015), https://au.int/sites/default/files/decisions/9664-assembly_au_dec_569_-_587_xxiv_e.pdf. Actual negotiations commenced in February 2016. 
operationalization of the CFTA, ${ }^{20}$ the Assembly adopted the Agreement Establishing the African Continental Free Trade Area on March 21, 2018. ${ }^{21}$ That historic agreement seeks to create conditions that permit the expansion of intra-African trade and the intensification of economic cooperation among states. It breathes life into the AEC Treaty, ${ }^{22}$ which remains the key normative framework for evaluating Africa's strategy for socio-economic development. The AU Assembly also adopted three complementary protocols with the AfCFTA Agreement to facilitate market integration. These are the Protocol on Trade in Goods, ${ }^{23}$ the Protocol on Trade in Services, ${ }^{24}$ and the Protocol on Rules and Procedures on the Settlement of Disputes. ${ }^{25}$ The AfCFTA Agreement provides that any additional instruments within its scope, as deemed necessary, "shall be concluded in furtherance of the objectives of the AfCFTA and shall, upon adoption, form an integral part of th[e] Agreement." 26 This provision clearly anticipates additional protocols that should be elaborated on and adopted when the ongoing negotiation rounds are completed. The three protocols under reference do not contain separate ratification provisions; only the AfCFTA Agreement does. ${ }^{27}$ When the Agreement enters into force, the protocols "shall form part of the single undertaking," 28 meaning that they have the same normative force as the principal treaty. ${ }^{29}$ This arrangement is intended to ensure that parties to the AfCFTA Agreement do not cherry pick which treaty obligations to implement. In the CFTA legal regime, all rights and

20. Decision on Boosting Intra-African Trade, supra note 16, para. 4.

21. Agreement Establishing the African Continental Free Trade Area, adopted Mar. 21, 2018, 58 I.L.M. 1028 [hereinafter AfCFTA AGT] (entered into force May 30, 2019).

22. See id., pmbl. (noting the launch of negotiations to establish the AfCFTA was to integrate Africa's markets "in line with the objectives and principles enunciated in the Abuja Treaty.....") (emphasis in the original).

23. AfCFTA AGT, Protocol on Trade in Goods, Mar. 21, 2018, 58 I.L.M. 1028, 1043 [hereinafter Protocol on Trade in Goods].

24. AfCFTA AGT, Protocol on Trade in Services, Mar. 21, 2018, 58 I.L.M. 1028, 1053 [hereinafter Protocol on Trade in Services].

25. AfCFTA AGT, Protocol on Rules and Procedures on the Settlement of Disputes, at 54, Mar. 21, 2018, 58 I.L.M. 1028, 1067 [hereinafter Protocol on DSM Rules].

26. AfCFTA AGT, supra note 21, art. 8(3).

27. See id. art. 22.

28. Id. art. 8(2). The "single undertaking" device approximates the legal framework of the Marrakesh Agreement. Marrakesh Agreement Establishing the World Trade Organization, art. 2(2), Apr. 15, 1994, 1867 U.N.T.S. 154 [hereinafter Marrakesh AGT]. Only the Plurilateral Trade Agreements do not create either rights or obligations for members that have not accepted them. Id. art. 2(3).

29. Cf. Customs Régime between Germany and Austria, Advisory Opinion, 1931 P.C.I.J. (ser. A/B) No. 41, at 47 (Sept. 5) ("From the standpoint of the obligatory character of international engagements, it is well known that such engagements may be taken in the form of treaties, conventions, declarations, agreements, protocols, or exchanges of notes."). 
obligations go together. The Agreement even prohibits any reservation, ${ }^{30}$ the rationale being to preserve the integrity of the undertakings, which parties value higher than any effort at larger participation. ${ }^{31}$

Timely ratification of treaties is not a virtue in Africa. Many regional treaties are yet to enter into force, more than a decade since their adoption. ${ }^{32}$ The AfCFTA Agreement is a refreshing exception to the norm. It entered into force within thirteen months of its adoption - on May 30, 2019-after meeting the 22 ratification threshold. ${ }^{33}$ All AU members, minus Eritrea, have signed the AfCFTA Agreement. Twenty-eight, or 50.9 percent, of the $55 \mathrm{AU}$ members have ratified it. ${ }^{34}$ The unprecedented record of attainment of the minimum ratifications evinces a commitment to fast-track the CFTA, at least in principle. In the likely event of all the AfCFTA Agreement attaining general ratification, the CFTA will cover a population of 1.3 billion. ${ }^{35}$ With an estimated gross domestic product (GDP) of $\$ 2.5$ trillion, it will be the world's largest free trade zone since the establishment of the WTO in $1995 .^{36}$

30. See AfCFTA AGT, supra note 21, art. 25; Vienna Convention on the Law of Treaties, art. 19(a), May 22, 1969, 1155 U.N.T.S. 331, 8 I.L.M. 679 [hereinafter VCLT] (entered into force Jan. 27, 1980) (permitting such prohibition).

31. Robert Kolb, The LaW of Treaties: An Introduction 72 (2016) ("This is true for institutional schemes, which can function only on the basis of one single set of rules.").

32. See, e.g., Inter-African Convention Establishing an African Technical Co-operation Program, Aug. 1, 1975, https://au.int/sites/default/files/treaties/36408-treaty-0007_-_inter-african_convention_ establishing_an_african_technical_co-operation_programme_e.pdf (not yet in force); Convention for the Establishment of the African Centre for Fertilizer Development, July 1, 1985, https://au.int/sites/default/files/treaties/7772-treaty-0012_-_convention_for_the_establishment_of_the_ african_centre_for_fertilizer_development_e.pdf (not yet in force); African Maritime Transport Charter, June $11, \quad 1994, \quad \mathrm{https}: / /$ au.int/sites/default/files/treaties/37306-treaty-0017___african_maritime_ transport_charter_e.pdf (not yet in force); Charter for African Cultural Renaissance, Jan. 24, 2006, https://au.int/sites/default/files/treaties/37305-treaty-0032___charter_for_african_cultural_renaissance_ e.pdf (not yet in force); Protocol on the Statute of the African Court of Justice and Human Rights, adopted July 1, 2008, 48 I.L.M. 317 [hereinafter Sharm El-Sheikh Protocol] (not yet in force); Protocol on the African Investment Bank, June 30, 2009, https://au.int/sites/default/files/treaties/36414-treaty-0038__protocol_on_the_african_investment_bank_e.pdf(not yet in force).

33. AfCFTA AGT, supra note 21, art. 23(1). Only the AU Act, which was adopted on July 11, 2000 and entered into force within ten months on May 26, 2001, rivals the AfCFTA Agreement.

34. African Continental Free Trade Area (AfCFTA) Legal Texts and Policy Documents, TRALAC, https://www.tralac.org/resources/our-resources/6730-continental-free-trade-area-cfta.html (last visited Oct. 10, 2020). For the ratification status of the AfCFTA Agreement, see African Union [AU], List of Countries Which Have Signed, Ratified/Acceded to the Agreement Establishing the African Continental Free Trade Area (Oct. 8, 2019) [hereinafter AfCFTA, Ratification Status], https://au.int/sites/default/files/treaties/36437-sl-AGREEMENT\%20ESTABLISHING\%20THE\%20 AFRICAN\%20CONTINENTAL\%20FREE\%20TRADE\%20AREA\%20\%282\%29.pdf.

35. African Countries by Population, WORLDOMETERS [hereinafter WORLDOMETERS], https://www.worldometers.info/population/countries-in-africa-by-population/ (last visited Oct. 6, 2020).

36. African Continental Free Trade Area-Questions \& Answers, UNECA, [hereinafter UNECA, $Q \& A], \quad \mathrm{https} / /$ www.uneca.org/archive/publications/african-continental-free-trade-area-questionsanswers (last visited Oct. 10, 2020). 
Some notable economies that have ratified the AfCFTA Agreement include South Africa, Egypt, Ghana, and Kenya, ${ }^{37}$ representing a combined population of roughly 246 million. ${ }^{38}$ However, some notable economies that have not yet ratified include Nigeria with a GDP per capita of $\$ 2,229.90$ as of $2019,{ }^{39}$ Angola with a GDP per capita of $\$ 2,973.60,{ }^{40}$ Algeria with a GDP per capita of $\$ 3,948.30,{ }^{41}$ and Morocco with a GDP per capita of $\$ 3,204.10 .^{42}$ The four countries have a combined population of roughly 319 million. ${ }^{43}$ More states will hopefully ratify in the near future, after a cost-benefit analysis on the potential benefits of an integrated regional economy.

Some commentators opine that Africa has largely turned its backs on the rhetoric of a 'new international economic order' (NIEO) ${ }^{44}$ to embrace more modern, liberal, economic dogmas. ${ }^{45}$ They could readily point to the AfCFTA Agreement to support their position. The Agreement embraces some neo-liberal principles, including trade liberalization. ${ }^{46}$ Neo-liberalism, sometimes called the 'Washington Consensus,' insists that only the 'invisible hands' of free trade should allocate labor, capital, and technological resources in order to ensure prosperity and protect democracy from despotism. ${ }^{47}$ A variant of this ideology is libertarianism, which holds, among other tenets, that governments have no social responsibilities except

37. See AfCTFA, Ratification Status, supra note 34 (listing countries that have ratified the AfCFTA Agreement).

38. WORLDOMETERS, supra note 35.

39. GDP Per Capita (Current US\$), WORLD BANK, https://data.worldbank.org/indicator/NY.GDP.PCAP.CD (last visited Oct. 6, 2020).

40. Id.

41. Id.

42. $I d$

43. See WORLDOMETERS, supra note 35 (listing countries by population, including Nigeria, Angola, Algeria, and Morocco).

44. The NIEO sought, inter alia, to eliminate developing countries' economic dependence on developed countries and to accelerate developing countries' economies based on the principle of selfreliance. See G.A. Res. 3201, Declaration on the Establishment of a New International Economic Order (May 1, 1974) [hereinafter Declaration on NIEO] (referring to the UN Charter's principles of promoting economic advancement and social progress when outlining the reasons for establishing the NIEO). See generally P.N. AgARWALA, THE NEW INTERNATIONAL ECONOMIC ORDER: AN OVERVIEW (2014) (providing information about the NIEO's influence on the world economy).

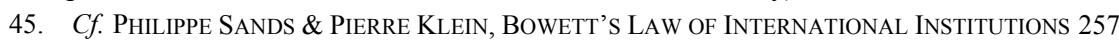
(6th ed. 2011) (arguing that the creation of economic co-operation organizations alone will not overcome structural economic problems).

46. AfCFTA AGT, supra note 21, art. 3(b) (seeking to create a liberalized market for goods and services).

47. See generally HANDBOOK OF NEOliberalism (Simon Springer et al. eds., 2016) (providing a comprehensive overview of neoliberalism's theoretical underpinnings, political implications, and place in emerging debates); DAVID HARVEY, A BRIEF History OF NEOLIBERALISM (2007) (showing a panoramic view of neoliberalism and how it profiteered on the world stage). 
to maintain law and order. Sachs calls this philosophy "a grand illusion," as it is not grounded in history or sound economic theory. ${ }^{48}$ But critiques of neo-liberalism have plausible reasons for concern; indeed, segments of Africa's civil society are skeptical of the CFTA. In an incisive essay the same year, Kombo argued that "one of the dangers of free trade ideology is its hegemonic foreclosure of alternatives," and that Africa "cannot afford to be the perpetual testing ground for unsubstantiated economic theories." 49

This paper undertakes a contextual analysis of the AfCFTA Agreement, partly in response to the UNECA's call to African scholars to support the effective realization of this new development initiative. ${ }^{50}$ It examines the context that led to the text of the Agreement, its contours, and its potential effectiveness, particularly in a continent where states still cage themselves in concrete walls of sovereignty. This paper demonstrates that the CFTA is an Afrocentric vision designed to enable collective Africa to find 'African solutions' to its peculiar economic challenges. It is a synthesis of free market principles and regional specificities, as articulated in earlier instruments such as the LPA, AEC Treaty, the New Partnership for Africa's Development (NEPAD), ${ }^{51}$ AU Act, and Agenda 2063. ${ }^{52}$ Africa cannot operate in isolation in a globalized world, so the CFTA is designed not only to enhance intraAfrican trade but also to increase Africa's participation in the global market. ${ }^{53}$ The paper proceeds on four main tracks. The first track examines Africa's quest for an endogenous development paradigm, as exemplified in the LPA and AEC Treaty. The second track interrogates the new paradigm represented by the AfCFTA Agreement and its protocols. It focuses on some issues that are fundamental to the creation of an AEC/CFTA, including its

48. JefFrey SACHS, THE PRICE OF CiVILIZATION: REAWAKENING VIRTUE AND PROSPERITY AFTER THE ECONOMIC FALL 37-38 (Rev. ed. 2012) (“[F]ree markets alone cannot begin to ensure efficiency and prosperity; without government, we'd lack the highways, safe environment, public health, and scientific discoveries that make us productive.").

49. Brenda K. Kombo, What Are the Alternatives to Neoliberal Trade?, AFr. Is A COUNTRY (May 2, 2019), https://africasacountry.com/2019/05/what-are-the-alternatives-to-neoliberal-trade (calling for a "robust intellectual engagement" to unpack the AfCFTA).

50. Shi Yinglun, ECA Official Urges African Scholars to Develop Quality Research on Free Trade Pact, XINHUANET (Mar. 15, 2019, 1:26 PM), http://www.xinhuanet.com/english/201903/15/c 137897583.htm.

51. African Union [AU], The New Partnership for Africa's Development, paras. 7-8 (Oct. 2001) [hereinafter NEPAD FD], https://www.un.org/en/africa/osaa/pdf/nepad/nepad.pdf.

52. See African Union [AU], Agenda 2063-The Africa We Want: Popular Version, paras. 9-10 (May 2016) [hereinafter Agenda 2063], https://au.int/sites/default/files/documents/33126-doc03 _popular_version.pdf.

53. See AfCFTA AGT, supra note 21, art. 3(g); cf. Agenda 2063, supra note 52, para. 66 ("Reaffirms that Agenda 2063 builds on past achievements and challenges and takes into account the continental and global context and trends in which Africa is realizing its transformation ....") (emphasis added). 
scope of application. The third track interrogates the vertical and horizontal relationships between the AEC/CFTA and regional economic communities (RECs), on one hand, and member states on the other. It examines, for example, the effect of Community law or regulations on national law. In the final track, it highlights indicators for measuring the success of the CFTA. The paper concludes that social justice must accompany economic growth; that is, and must remain, the summum bonum - the ultimate goal.

Law has always played a significant role in states' economic relations and will continue to do so. Multilateral treaties like the AfCFTA Agreement are important sources of international economic and institutional law. They advance efforts towards establishing norms of global and regional governance. ${ }^{54}$ In addition, states' votes and views in international organizations constitute evidence of customary law; ${ }^{55}$ likewise the practice of the organizations themselves, which increasingly impact the development of international (economic) law. ${ }^{56}$ International economic law, in particular, serves as the pivot or anchor for this paper. I also call in aid decisions of AU policy organs as subsidiary means for the determination of the rules of law. ${ }^{57}$ All of these sources of law, alongside economic theories and political and moral philosophy, are synthesized to advance the thesis that the CFTA is a unique development initiative.

\section{AFRICA'S QUEST FOR AN ENDOGENOUS DEVELOPMENT PARADIGM}

Post-colonial states have tried, with mixed results, to create an endogenous paradigm to improve the living standards of their peoples and confront the vagaries of neo-liberal globalization. These steps have been marked by an awareness that foreign aid, debt relief, technical assistance, and other international strategies are inadequate to sustain development. ${ }^{58}$ Economic integration is generally seen as key to overcoming fragmentation, promoting diversification, accelerating transformation and sustainable development, and building cross-border linkages among productive

54. See Udombana, The AfricAn Union supra note 15 , at 16.

55. Rosalyn Higgins, THE DEVELOPMENT OF InTERNATIONAL LAW THROUGH THE POLITICAL ORGANS OF THE UNITED NATIONS 3 (1963) ("Collective acts of States, repeated by and acquiesced in by sufficient numbers with sufficient frequency, eventually attain the status of law."); see also UDOMBANA, THE AFRICAN UNION, supra note 15, at 16.

56. See Simon Chesterman et AL., LAW AND PRACTICE OF THE United NATIONS: Documents AND COMMENTARY 8-10 (2d ed. 2016) (emphasizing that organizations' actions and practices can serve as authoritative sources for interpreting treaties).

57. See Sharm El-Sheikh Protocol, supra note 32, art. 31(1)(e).

58. See Muna Ndulo, African Integration Schemes: A Case Study of the Southern African Development Community, 7 AFR. Y.B. INT’L L. 3, 4-5 (1999). 
entities. ${ }^{59}$ This belief obviously motivated the many regional 'economic communities (RECs) ${ }^{60}$ that sprung up in Africa in the 1960s and beyond. The EAC, the Economic Community of West African States (ECOWAS), the Common Market for Eastern and Southern Africa (COMESA), ${ }^{61}$ the Southern African Development Community (SADC), ${ }^{62}$ and others have made varying progress on trade liberalization and facilitation, free mobility, infrastructure, and even peace and security ${ }^{63}$ However, a framework was needed to boost, coordinate, and transform these RECs into engines for continental economic growth. The LPA of 1980 laid the foundation for that framework. The AEC Treaty of 1991 built on it. Both instruments were prominent initiatives by which African states collectively sought to reengineer themselves in the last two decades of the last millennium.

In this part, I examine Africa's long quest for endogenous development. I begin with a note on the concept and benefits of economic integration to serve as a literature review and provide a framework for some of the critical issues examined in this part and the rest of the paper. I then proceed to examine the LPA, the AEC Treaty, and the African Union's continuing roadmap towards an AEC. I finally attempt a preliminary assessment of these efforts. I conclude that despite the obvious benefits of integration, few demonstrable achievements have been evident at the continental level in Africa. This failure obviously informs the renewed effort to integrate Africa through the CFTA.

59. See generally MARY E. LOVELy, InTERNATIONAL ECONOMIC INTEGRATION AND DOMESTIC PERFORMANCE (2016) (discussing the influence of international economic integration on certain domestic issues such as tax burdens, welfare policies, and environmental regulations); INTERNATIONAL ECONOMIC INTEGRATION (Franz Lang \& Renate Ohr eds., 2012) (arguing that the power of international economic integration can determine domestic tax burdens, influence welfare implications of domestic policy alternatives, and influence the location of productive factors and their rewards); MAURICE SCHIFF \& L. Alan Winters, REgional InTEgRATION AND DEVElopment (2003) (discussing the relationship between regionalism and multilateralism while exploring the economic advantages of non-discriminatory trade liberalization).

60. Defined as "corporate legal entity established by its Treaty ... and whose objective is to promote economic integration." Protocol on Relations Between the African Union and the Regional Economic Communities, art. 1, July 1, 2017 [hereinafter AU Protocol on RECs], https://archives.au.int/bitstream/handle/123456789/1621/Protocol_Relations_AU_RECs_E.pdf?sequenc $\mathrm{e}=1$ \&isAllowed $=\mathrm{y}$.

61. For legal text, see Common Market for Eastern and Southern Africa, Nov. 5, 1993, 33 I.L.M. 1067 [hereinafter COMESA Treaty].

62. Treaty of the Southern African Development Community, Aug. 17, 1992, 32 I.L.M. 116 [hereinafter SADC Treaty].

63. UNECA, ASSESSING REGIONAL INTEGRATION, supra note 7, at 1. 
A. Note on Economic Integration

Economic integration entails the amalgamation, regulation, and the establishment of a common market. Trade is the building block of that tripod. In this section, I examine the concept and benefit of integration. The exercise serves as a prelude to the subsequent analysis of the quest for a continental economic union, as represented in the LPA, AEC Treaty, and now the AfCFTA Agreement.

\section{The Concept of Integration}

Economic integration is the fusion of two or more national economies into one, with major economic policies decided in common. It is a selective trade liberalization with regional partners, allowing for goods, services, persons, and capital to circulate freely but without affecting trade relations with third parties. ${ }^{64}$ The WTO allows its members to establish and enlarge regional trade agreements (RTAs), subject to stringent conditions and the requirement of notification. Article XXIV of the General Agreement on Tariffs and Trade (GATT) ${ }^{65}$ and the 1994 Understanding on the Interpretation of Article XXIV ${ }^{66}$ that "substantially all the trade" between the RTA members should be liberalized. ${ }^{67}$ It further enjoins Customs Union members to apply substantially the same duties and other trade restrictions to products of third parties, ${ }^{68}$ including eliminating discriminatory standards in customs union agreements.

64. See Nsongurua J. Udombana, A Harmony or a Cacophony? The Music of Integration in the African Union Treaty and the New Partnership for Africa's Development, 13 IND. INT'L \& COMP. L. REV. 185, 187 (2002) [hereinafter Udombana, A Harmony or a Cacophony?] (referencing PHILIP MARC

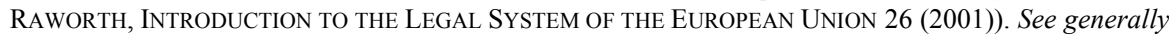
André Sapir, European Integration at the Crossroads: A Review Essay on the 50th Anniversary of the Bela Balassa's Theory of Economic Integration, 49 J. ECON. LITERATURE 1200 (2011) (analyzing developments in European economic integration over the last fifty years since the publishing of Bela Balassa's book to present a detailed picture of the theory of economic integration through a discussion of scale economies, imperfect competition, and economic geography).

65. General Agreement on Tariffs and Trade, Apr. 15, 1994, 1867 U.N.T.S. 190, 33 I.L.M. 1154 [hereinafter GATT 1994]; $c f$. General Agreement on Tariffs and Trade, art. XXIV, Oct. 30, 1947, 61 Stat. A-11, 55 U.N.T.S. 194 (first established version of the GATT) [hereinafter GATT 1947] (providing a number of exceptions to the Most-Favored-Nations principle). For a detailed analysis of Article XXIV of GATT, see JOHN. H. JACKSON ET AL., LEGAL PROBLEMS OF INTERNATIONAL ECONOMIC RELATIONS 452-65 (4th ed. 2002).

66. See, e.g., Understanding on the Interpretation of Article XXIV of the General Agreement on Tariffs and Trade 1994, in WTO-INSTITUTIONS AND DisPUTE SETTLEMENT (Rudiger Wolfrum et al. eds., 2006).

67. GATT 1994, supra note 65, art. XXIV(8)(b) (referring to the greater number of free trade areas (FTAs) since the establishment of the GATT); $i d$. art. XXIV(8)(a)(i) (referring to the increase and greater importance of customs unions).

68. See id. art. XXIV(8)(a)(ii). 
Critics of RTAs see them as a second-best option to integrate developing regions into the global economy. ${ }^{69}$ Others comment on the risk of trade diversion. This occurs when import supplies from countries outside the region are replaced by less efficient production from countries within the region. They argue that trade creation causes losses among non-members. ${ }^{70}$ A further argument is that RTAs are at odds with the WTO's policies of multilateralism and economic liberalism; and that regional deals, despite their political appeal, are never a substitute for progress at the WTO. ${ }^{71}$ Multilateral trade rounds, they insist, are the trading system's foundation, based on the 'most favored nation' treatment- the principle that any tariff cuts offered to one country must be offered to all. It makes no sense, says the Economist, "to endorse regionalism at the expense of a better multilateral system." 72 The problem with this argument is its underlying assumption, that global trade is the sole panacea to the economic ills faced by developing countries. The evidence does not support such an assumption. ${ }^{73}$ The failed Doha Development Round (DDR), launched in November 2001 to free global trade and extend the benefits of globalization to developing countries, has only accelerated the rush to negotiate more RTAs. ${ }^{74}$ The CFTA is one among several such RTAs that have come into force since Doha. More will certainly follow.

\section{The Potential Benefits of Integration}

There is a broad consensus on the benefits of economic integration. ${ }^{75} \mathrm{It}$ could help to remove trade distortions and encourage competition, investment and factor mobility, thereby allowing participating states to

69. See, e.g., Scott Flatto, Note, Too Much of a Good Thing?: Reassessing the Proliferation of African Regional Trade Agreements, 30 SufFolK TrANSNAT'L L. REV. 407, 409 (2007).

70. See Craig Jackson, Constitutional Structure and Governance Strategies for Economic Integration in Africa and Europe, 13 TRANSNAT'L L. \& CONTEMP. PROBS. 139, 140 n.4 (2003) (referencing RAJ BHALA, INTERNATIONAL TRADE LAW: THEORY AND PRACTICE 635-50 (2d ed. 2001)).

71. Regional Trade Agreements: A Second-Best Choice, ECONOMIST (Sept. 4, 2008), http://www.economist.com/opinion/displayStory.cfm?story id=12068114.

72. $I d$.

73. See fatoumata Jawara \& Aileen Kwa, Behind the Scenes at the WTO: The Real WORLD OF INTERNATIONAL TRADE NEGOTIATIONS (Rev. ed. 2004) (countering the myth that developing countries are well-served by the WTO).

74. See Afta Doha, Should Free Traders Applaud the Rise of Preferential Trade Deals?, ECONOMIST (Sept. 4, 2008), https://www.economist.com/finance-and-economics/2008/09/04/afta-doha.

75. See generally J.E. Weaver, The Costs and Benefits of Economic Integration, 44 AFR. STUD. REV. 211 (2001) (reviewing 1-4 REgIONAL INTEGRATION AND TRADE LIBERALIZATION IN SUBSAHARAN AFRICA (Ademola Oyejide et al. eds., 1997)) (discussing the four-volume work's comprehensive study on how trade liberalization can create greater ties between Africa and the world). 
maximize utility and increase welfare. ${ }^{76}$ The liberalised market of the participating states and the increased specialisation consistent with the law of comparative advantage could lead to enhanced efficiency in production. ${ }^{77}$ Integration could enhance competitiveness at the industry and enterprise level by exploiting opportunities for economies of scale, continental market access and an efficient allocation of resources. ${ }^{78}$ It could lead to "sustainability, increased investment, the consolidation of economic and political reforms, increased global competitiveness, the promotion of regional public goods, [and] the prevention of conflict." ${ }^{, 79}$ The intensified competition between firms leads to enforced changes in efficiency. And the resulting technological advances produce changes in the amount and quality of the factors of production. ${ }^{80}$ This could also help to stimulate the global economy. ${ }^{81}$ Regional integration could enable states to share, in an equitable manner, the advantages of cooperation for a balanced development. ${ }^{82}$ Integration deepens solidarity between nations; indeed, cooperative regimes embody commitments to shared values, including democratic and pluralistic politics. $^{83}$

For Africa, integration could enable it to build resilience to global output shocks. An empirical study has revealed that deeper integration within the EAC helped its members to absorb such shocks during the global financial crisis of 2007-2008. ${ }^{84}$ In contrast, the Southern Africa Custom Union (SACU) was less able to cope during the same period partly due to weaker regional integration. ${ }^{85}$ A pooled economy will also enable Africa to enhance its bargaining position at the global level, thereby resulting in better trade deals - cheaper imports from the outside and higher prices for exports. Acting independently, African states will not have the bargaining power to secure good or even better terms of trade in a field that has China, the E.U.,

76. Cf. Protocol on Trade in Goods, supra note 23, pmbl. (linking increased investment and the elimation of trade barriers with economic efficiency and improving welfare).

77. Ali M. El-AgraA, The European Union: ECONOMics And Policies 18 (7th ed. 2004).

78. $C f$. Protocol on Trade in Goods, supra note 23, pmbl. (resolving to enhance industry competitiveness through leveraging economies of scale, contintental market access and efficient resource allocation).

79. UNECA, ASSESSING REGIONAL INTEGRATION, supra note 7, at x.

80. See id.

81. See Matthias Herdegen, Principles of InTERnAtional ECONOMIC LAW 321 (2d ed. 2016).

82. See AEC Treaty, supra note 12, pmbl.

83. Samuel P. Huntington, The Clash of Civilizations and the Remaking of World ORDER 302 (1996).

84. For an analysis of the role between integration and ability to absorb financial shocks see, e.g., Mthuli Ncube et al., Can Intra-Regional Trade Act as a Global Shock Absorber in Africa? (William Davidson Inst., Working Paper No. 1073, 2014), https://ssrn.com/abstract=2400550.

85. Id. 
India, and the U.S. among its players. One only needs to imagine China negotiating with some weak post-colonial states-like Seychelles (population 98,347 ${ }^{86}$ ), Sao Tome \& Principe (population 219,159 ${ }^{87}$ ), Cape Verde (population 555,987 $7^{88}$ ), or Comoros (population $869,601^{89}$ ) - to appreciate the saying that two are better than one. According to an African proverb, if you cross the river in a crowd, you will not be eaten by the crocodile. Of course, a pooled economy assumes that Africa maintains common positions on trade and related issues, which is one of the goals of the $\mathrm{AU}^{90}$

A continental free trade area will make Africa a more attractive investors' destination. Africa's economic size contains possibilities for growth that are absent in any one of the fifty-five odd states. It is estimated that a successful CFTA will have a combined consumer and business spending of $\$ 6.7$ trillion by $2030 .{ }^{91}$ As long as individual states attempt to 'go it alone,' Africa will lose out in the increasing global competition for Foreign Direct Investment (FDI). ${ }^{92}$ Few states, if any, will achieve the real economic independence and higher living standards to which Africa aspires. ${ }^{93}$ A harmonized rule of origin and disciplines on tariff and non-tariff measures will make it easier for foreign firms to trade in Africa. An investor in one state would be able to sell to, or invest, in the rest of Africa. ${ }^{94}$

\section{B. The Lagos Plan of Action}

The LPA was arguably Africa's first concrete attempt to create a common policy framework for a self-reliant development through the establishment of an AEC. It was, at the time of its adoption, the most comprehensive and systematic vision for Africa's development. ${ }^{95}$ The

86. WORLDOMETERS, supra note 35.

87. Id.

88. Id.

89. Id.

90. See AU Act, supra note 14, art. 3(d); AEC Treaty, supra note 12, art. 94(1).

91. See Landry Signé, How Africa is Bucking the Isolationist Trend, ForEIGN AFF. (May 23, 2018), https:/www.foreignaffairs.com/articles/africa/2018-05-23/how-africa-bucking-isolationist-trend.

92. See UNCTAD, HANDBOOK OF STATISTICS, at 49-52, U.N. Doc. TD/STAT.43, U.N. Sales No. E.19.II.D.1 (2018) ("FDI is defined as an investment reflecting a lasting interest and control by a foreign direct investor, resident in one economy, in an enterprise resident in another economy (foreign affiliate).").

93. See Reginald H. Green \& Ann Seidman, Unity or Poverty? The ECONOMics OF PanAFRICANISM 80-81 (1968).

94. See William Davis, The African Growth and Opportunity Act and the African Continental Free Trade Area, 111 AM. J. INT'L L. UNBOUND 377, 381 (2017).

95. See Claude AKe, Democracy and DeVelopment in Africa 22 (1996). 
Monrovia Declaration of $1979^{96}$ provides insights to the nature of challenges that states sought to address in the LPA and later the AEC Treaty. The first was the challenge of economic and social restructuring to achieve rapid socio-economic change and establish a solid domestic and intra-African base for a self-sustaining and self-reliant development. ${ }^{97}$ The second was the challenge of mobilizing political support for the restructuring. ${ }^{98}$ In response, states committed themselves, individually and collectively, to prioritizing human resource developments in order to eliminate illiteracy. They pledged to put science and technology in the service of development. They pledged to work towards self-sufficiency in food production and supply. They pledged to co-operate in the field of natural resources control, exploration, extraction and use for development. They pledged to develop indigenous entrepreneurial, technical manpower and technological capabilities to achieve individual and collective development goals. They pledged to cooperate in the preservation, protection and improvement of the natural environment, to ensure that development policies reinforce Africa's cultural identity, and to take the future into account in the elaboration of development plans. ${ }^{99}$ Following this long list of commitments, the Monrovia Declaration called for the creation of an African Common Market (ACM) as a prelude to an AEC. ${ }^{100}$

The LPA was the immediate successor to the Monrovia Declaration. It references the Declaration in three preambular paragraphs, ${ }^{101}$ indicating a common goal of self-reliance. In this section, I examine the rhetoric of selfreliance and how the destructive force of neo-liberalism derailed the LPA vision.

1. The Rhetoric of Self-Reliance

The LPA was a classic work on endogenous development strategy, with a rigorous and clear vision of sustainable, equitable, and poverty-reducing growth accompanied by structural transformation. ${ }^{102}$ It was exclusively devoted to Africa's economic problems, describing itself as "a far-reaching

96. Monrovia Declaration of Commitment of the Heads of State and Government, of the Organization of African Unity on the Guidelines and Measures for National and Collective Self-reliance in Social and Economic Development for the Establishment of a New International Economic Order, Assembly of Heads of State and Government, Sixteenth Ordinary Session, AHG/ST.3(XVI)Rev.1 (July 17, 1979) [hereinafter Monrovia Declaration], https://au.int/sites/default/files/decisions/9526assembly_en_17_20_july_1979_assembly_heads_state_government_sixteenth_ordinary_session.pdf.

97. Id. pmbl.

98. See id.

99. Id. para. 4.

100. Id. para. 5 .

101. LPA, supra note 11, paras. 2-4.

102. See AKE, supra note 95, at 22. 
regional approach" for the basic restructuring of Africa's economic base, anchored primarily on collective self-reliance. ${ }^{103}$ The LPA began with a critical assessment of the then prevailing global development strategies, concluding that Africa could not point a significant growth rate or satisfactory index of general well-being after faithfully implementing the global economic strategies. ${ }^{104}$ It added, ominously, that "if the world economic forecast for the next decade [was] to be believed, the over-all poor performance of the African economy over the past 20 years may even be a golden age compared with future growth rate." 105 The LPA reflected on some of the reasons for the continent's woes, among them the systemic and serial exploitation of Africa's resources during the colonial period. ${ }^{106}$ That exploitation, which left Africa bleeding, continued after independence through neo-colonialism. Many external forces still seek to influence the economic policies and directions of Africa. ${ }^{107}$ Natural and endemic diseases "of the cruelest type" complicate the problem. ${ }^{108}$ The LPA also viewed, with disquiet, Africa's over-dependence on export of basic raw materials and minerals, a phenomenon that has made African economies highly susceptible to external developments and been detrimental to its internal interests. ${ }^{109}$ As this paper will later articulate, this export of primary materials remains.

The LPA developed a set of guidelines for self-reliant development. ${ }^{110}$ First, that Africa's resources must be applied principally to meet the needs of its people. Second, that Africa must cultivate the virtue of self-reliance and mobilise her entire human and material resources for development, and that external economic assistance should not be the mainstay of development. Third, that Africa's development and growth must be based on a combination of natural resources, entrepreneurial, managerial and technical resources, and a restructured and expanded market. Fourth, that each state should pursue an all-embracing strategy of economic, social and cultural activities by mobilising its strength to ensure equitable shared efforts in development and its outcome. Lastly, and more relevant to this paper, that collective Africa should renew its pursuit of economic integration for the much-needed development based on collective self-reliance. Guided by these principles, the OAU mapped out sectoral issues on which its members

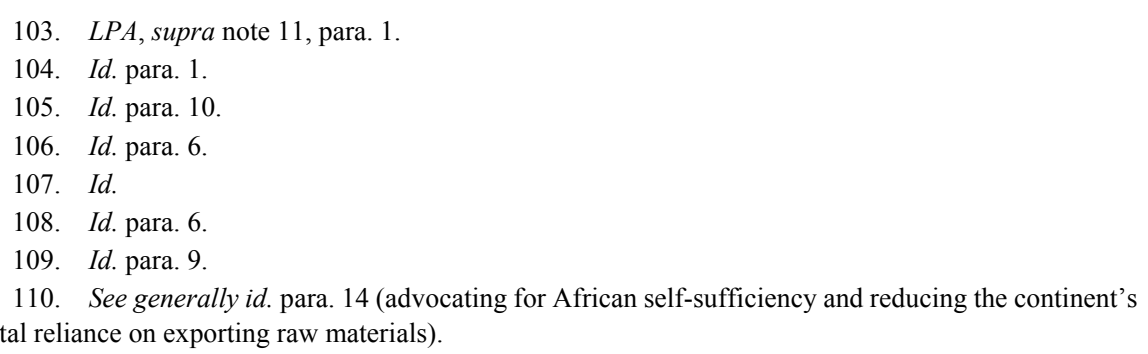


were required to give priority attention. ${ }^{111}$ These were agriculture, industry, natural resources, human resource development and utilization, science and technology, transport and communications, and trade and finance. By concentrating on sectoral programs, the LPA envisaged structural transformation of African economies. ${ }^{112}$ It linked self-sufficiency to Africa's economic integration: "We commit ourselves individually and collectively, on behalf of our governments and peoples, to establish national, sub-regional and regional institutions which will facilitate the attainment of objectives of self-reliance and self-sustainment." ${ }^{113}$ But 'self-reliance' was not envisaged to result in a complete autarky or absolute national self-sufficiency. ${ }^{114}$ It was meant to reduce dependence on foreign investment and economic assistance, by combining extremely limited individual markets and scarce resources to forcefully bargain for foreign capital and technology. ${ }^{115}$

A 'Final Act' accompanied the LPA - a Plan of Action towards realizing the commitments made in the LPA and ensuring Africa's economic, social, and cultural integration. ${ }^{116}$ The Final Act provided for strengthening existing RECs and establishing new ones where none existed. It provided for a deepening of sectoral integration by harmonizing strategies, policies and development plans. It enjoined the promotion of more intraAfrican trade and realization of self-sufficiency in food production. It called for the establishment of an energy policy, improvement in transport communications in Africa, and establishment of an African Monetary Fund (AMF). The LPA and the Final Act laid the frameworks for the AEC Treaty that was adopted about a decade later.

2. The Destructive Force of Uncensored Neo-liberalism

The LPA failed to deliver on its grand promises because states surrendered decision-making autonomy to neo-liberal international financial institutions (IFIs) - the International Monetary Fund (IMF) and the World

111. See generally id. (promoting African economic development by concentrating on certain sectors to boost the continent's overall growth).

112. Olu Ajakaiye \& Afeikhena Jerome, Economic Development: The Experience of Sub-Saharan Africa, in InTERnATIONAL DEVELOPMENT: IDEAS, EXPERIENCE, \& PROSPECTS 732, 742 (Bruce CurrieAlder et al. eds., 2014).

113. LPA, supra note 11, para. 3(iii); cf. AU Act, supra note 14, art. 4(k) (espousing the "promotion of self-reliance" as a principle).

114. Thomas J. Biersteker, Self-Reliance in Theory and Practice in Tanzanian Trade Relations, 34 INT'L ORG. 229, 231 (1980).

115. James Thuo Gathit, African Regional Trade AgreEments as Legal Regimes 30 (2011)

116. See generally LPA, supra note 11, paras. 249-65 (emphasizing the importance of intra-African expansion and unity). 
Bank. ${ }^{117}$ In the hysteria for survival, these states capitulated to the free market assumptions of the IFIs. They failed to make a priori impact assessment of the neo-liberal pills on their economies before swallowing them. While the LPA was designed as a self-reliant development initiative to delink Africa from Western neo-liberalism, its architects assumed that Western governments and their FIs would finance such an indigenous development initiative. The Western governments were not prepared to accept such a self-contradictory policy of self-reliance and dependency; neither were the IFIs prepared to do business with Africa using Africa's development blueprint. Expectedly, the World Bank released its alternative development framework for Africa a year after the LPA was adopted. ${ }^{118}$ The Report, written by the so-called 'African Strategic Group', blamed Africa's economic weaknesses on domestic policy inadequacies and administrative constraints. Before recommending 'adjustments in policy,' the Bank argued that a reordering of priorities is essential to accelerate economic growth in Africa, ${ }^{119}$ which was partially correct. The Structural Adjustment Programs (SAPs) that followed were rooted in neoliberal ideology, with flawed distributional analysis and poor sequencing of reforms. ${ }^{120}$ The IFIs blithely exhorted states to liberalize their markets and eliminate distortions in prices, privatize public utilities, and devalue their currencies. They compelled them to dismantle industrial protection measures, remove government subsidies, and reduce budget deficits and size of the public sector. ${ }^{121}$ The IFIs made the implementation of such policies a pre-condition for debt re-scheduling, new loan facilities, and other concessions.

The legacy of the neo-liberal prescriptions of the IFIs vary from success in the 'East Asian Miracles' to failure in Africa. Yew asserts that South-East nations achieved faster growth by opening up their economies to trade and foreign investments, adding: "Their economic dynamism made them attractive as economic and political partners." 122 But the fact that others have had a mild or even no toothaches after a dental surgery does not make mine

117. See generally Richard N. GARDNER, StERLING-DOLlar DiPLOMACY: THE ORIGINS AND THE PROSPECTS OF OUR INTERNATIONAL ECONOMIC ORDER (1969) (discussing the making of international economic policy and the growing global economic influence of international financial institutions (IFIs)).

118. See generally Elliot Berg, World BANK, ACCELERATEd DEVELOPMENT IN Sub-SAHARAN AFRICA: AN AGENDA FOR ACTION (1981) (describing the World Bank's response of building upon the Lagos Plan to recognize Africa's growth opportunities).

119. Id.

120. See Paul Collier \& Jan Willem Gunning, The IMF's Role in Structural Adjustment, 109 ECON. J. 634, 634 (1999).

121. See Richard FAlK, Predatory Globalization: A CritiQue 1 (1999).

122. See, e.g., LEE KUAN YEW, From THIRD WORLD TO FIRST: THE SingAPORE STORY: 1965-2000 340 (2000). 
less painful. The SAPs were a colossal failure in Africa, because they promoted reforms that tended to remove serious price distortions without adequate attention to social services. By failing to take countries' specific needs into consideration, and by prescribing the same medication for different ailments, the World and IMF wrecked hitherto healthy economies in Africa. ${ }^{123}$ The SAPs led to Africa's lost decades of the 1980 s and 90s. ${ }^{124}$ It contributed to massive indebtedness, which was about $\$ 141$ billion at the end of 1987, including arrears of payments due. ${ }^{125}$ The NEPAD notes that only a few states managed to achieve a semblance of economic growth during the period. ${ }^{126}$ The SAPs turned out to be bitter herbs of poverty for the citizens, the majority of whom were already working for the equivalent of slave labor wages. ${ }^{127}$ Even Ghana, which the IMF often projects as a showpiece of SAPs in Africa, retrenched about 10,500 civil servants in 1987, 100,000 in 1988 , and 12,000 in $1989 .{ }^{128}$ In some countries, retrenched workers suffered long-lived and deep losses of income. ${ }^{129}$

Chile's reform experience in South America falls in-between the EastAsian and African experiences, though its economic prescriptions came from the 'Chicago Boys' rather than the IFIs. ${ }^{130}$ Some University of Chicago trained economists convinced the then Chiliean dictator Augusto Pinochet to apply free-market policies and open up the country's economy. ${ }^{131} \mathrm{He}$ agreed,

123. Cf. Joseph E. Stiglitz \& Andrew Charlton, Fair Trade for All: How Trade Can Promote DeVElopment 2 (2007) (detailing how industrialized countries have leveraged unequal bargaining power to force agreements that disadvatange developing countries); see also Kombo, supra note 49 (noting that SAPs weakened Africa's public sector, ravaged social services, and increased inequality).

124. See generally Limits OF ADJUSTMENT IN AFRICA: THE EFFECTS OF ECONOMIC LIBERALIZATION, 1986-94 (Poul Engberg-Pedersen et al. eds., 1996) (concluding Africa's economy has contracted in per capita growth with an additional deterioration in the position of certain economic groups, especially women).

125. See Douglas Rimmer, External Debt and Structural Adjustment in Tropical Africa, 89 AFR. Aff. 283, 283 (1990) (citing Percy S. Mistry, African Debt: The Case for Relief for SubSAHARAN AFRICA (1988)).

126. NEPAD FD, supra note 51, para. 24.

127. See Nsongurua J. Udombana, How Should We Then Live? Globalization and the New Partnership for Africa's Development, 20 B.U. INT'L L.J. 293, 313-14 (2002).

128. INT'L LABOR ORG. (ILO), FROM REDEPLOYMENT TO SUSTAINED EMPLOYMENT GENERATION: CHALlenges For GHANA's PROGRAMME OF ECONOMIC RECOVERY AND DEVELOPMENT 35 (1989).

129. See, e.g., Neil McCulloch et Al., Trade Liberalization and Poverty: A Handbook 147 (2001) (showing that the average unemployment duration of public-sector workers laid off in Guinea between 1985 and 1988 exceeded two years and that thirty percent were still unemployed in 1992).

130. See generally JuAn GABRIEL VALdÉs, PinOCHET's ECONOMISTS: THE CHICAGO SCHOOL OF ECONOMICS IN CHILE (2008) (illustrating the unique situation of a military coup implementing a free market strategy in a developing state).

131. See Anthony Boadle, Explainer: Chile's 'Chicago Boys,' a Model for Brazil Now?, REUTERS (Jan. 4, 2019, 12:52 PM), https://uk.reuters.com/article/us-brazil-politics-chicagoboys- 
and proceeded to abolish price controls, liberalize imports, and deregulate the financial market. The policies facilitated the inflow of foreign capital and initially jump-started the Chilean economy in the late 1970s. The oil-related economic crises of the early 1980s threw Chile into acute recession. ${ }^{132}$ Pinochet later replaced the 'Chicago Boys' with economists inclined towards state intervention and protectionism. ${ }^{133}$

The lesson from Africa's tragic experience with SAPs is that a general framework for development must always take into account the specific circumstances facing different countries and regions at different times. Market reforms alone cannot guarantee economic growth particularly in countries that are trapped by extreme poverty, illiteracy, massive debt overhang, AIDS, malaria and droughts. ${ }^{134}$ Privatization without regulation leads to consumer exploitation. ${ }^{135}$ Privatization without the necessary institutional infrastructure leads to asset stripping rather than wealth creation. Belatedly, the World Bank now argues that more attention should be paid to "the need for differentiated policy recommendations for countries at different stages of development. Differences between countries . . . lead to the need for different implications regarding the appropriate institutions and policy frameworks."136 It continued: "Greater emphasis on development strategy must be balanced against the now well-understood fact that there is no 'one-size fits all' solution to the challenges of promoting growth and overcoming poverty." 137 This shift in thinking came more than two decades after irreparable damage had been done to Africa's economies.

The negative effects of the neo-liberal policies live on in Africa. The situation is compounded by the impotence of many African states which appear to be indissolubly stuck with Western governments in the face of

explainer/explainer-chiles-chicago-boys-a-model-for-brazil-now-idUKKCN1OY1OU (detailing how University of Chicago trained economists were able to enact sweeping free market reforms in Chile).

132. Id.

133. Id.

134. See JefFrey SAChs, The END OF POVERTy: ECONOMIC POSSIBILITIES FOR OUR LifETIME 195 (2005) ("[F]ree trade zones would not suffice, nor would they relieve extreme poverty on any kind of realistic timetable.").

135. See Joseph E. Stiglitz, Globalization AND Its Discontents 220 (2003) (explaining how international organizations started accept the idea that a one size fits all approach to economic development is ineffective).

136. Alan Gelb et al., Research for Development: A World Bank Perspective on Further Directions for Research 10 (World Bank Policy Research, Working Paper No. 5437, 2010), https://www.researchgate.net/publication/228257638_Research_for_Development_A_World_Bank_Per spective_on_Future_Directions_for_Research.

137. Id. at 11 . 
destructive globalization. ${ }^{138}$ In Agenda 2063, the AU pledged to use the lessons from past and present development efforts and challenges to forge an African-centered approach to transformation. ${ }^{139}$ Going forward, the AU must urge its members not to abandon the driving seat of their economies to 'Development 1.0' theorists who focus only on free market ideas. Africa's march into the world economy does not follow a straight line. ${ }^{140}$ Wine can vary with every valley and vineyard.

\section{The African Economic Community (AEC) Treaty}

The establishment of an AEC has been a central goal in Africa's economic development vision. Although the LPA was not legally binding, it provided the framework for the AEC Treaty adopted a decade later. The Treaty establishes the AEC, ${ }^{141}$ or Community, ${ }^{142}$ to provide an institutional framework for economic integration in Africa. Economic integration and sustainable development run through the Monrovia Declaration, the LPA, and the AEC Treaty. The Treaty references these earlier instruments. ${ }^{143}$ State Parties also note efforts made in sub-regional sectoral economic cooperation, which justified a larger and fuller integration. ${ }^{144}$ In other words, the AEC seeks to harvest at the macro level the seeds sown at the micro levels of RECs in order to foster harmonious economic activity among participating members, advance higher living standards for citizens, and enhance peaceful relations among states. ${ }^{145}$

This section briefly interrogates the AEC Treaty, which remains the foundational document for Africa's economic integration agenda. The first segment examines the objectives of the AEC, the second examines the institutional modalities for its establishment, while the third examines the convoluted relationship between the OAU and the AEC that partly hampered progress towards integration.

138. See generally Giles Bolton, Africa Doesn't Matter: How the West Has Failed the POOREST CONTINENT AND WHAT WE CAN DO ABOUT IT (2008) (demonstrating how Western aid is ineffective in promoting Africa's economic development).

139. Agenda 2063, supra note 52, para. 3.

140. See Nsongurua J. Udombana, Social Rights Are Human Rights: Actualizing the Rights to Work and Social Security in Africa, 39 CORNELl INT'L L.J. 181, 215 (2006) [hereinafter Udombana, Social Rights Are Human Rights] (noting how various African reform movements have had varying levels of success).

141. See AEC Treaty, supra note 12, art. 2 (cementing the establishment of an African economic bloc).

142. The Treaty defines the word 'Community' as "the organic structure for economic integration." Id. art. 1. In this paper, the term 'AEC,' 'CFTA' and 'Community' are used interchangeably.

143. Id. pmbl.

144. Id.

145. Id. arts. 3(d), 4 . 
1. The AEC Objectives and Principles

Like the LPA before it, the AEC Treaty emphasizes solidarity and collective self-reliance. ${ }^{146}$ It seeks to integrate African economies for an indigenous and self-sustained development. ${ }^{147}$ It also seeks to promote cooperation in all fields and to coordinate and harmonize policies among existing RECs in order to foster the gradual establishment of the AEC. ${ }^{148}$ To achieve these goals, member states commit to harmonize their national policies to promote Community activities - "particularly in the fields of agriculture, industry, transport and communications, energy, natural resources, trade, money and finance, human resources, education, culture, science and technology."149 They further commit themselves to adopt a common trade policy vis-à-vis third states, establish and maintain a common external tariff, and establish a common market. They commit themselves to "the gradual removal, among [members], of obstacles to the free movement of persons, goods, services and capital and the right of residence and establishment." 150

The AEC Treaty affirms some free-market principles such as trade liberalization. It seeks to abolish customs duties levied on imports and exports by participating states as well as non-tariff barriers, in order to establish a free trade area in each REC. ${ }^{151}$ The next part will examine these free-market principles in the context of the AfCFTA Agreement.

2. Modalities for Establishing the AEC

The AEC Treaty sets up detailed modalities for establishing the AEC through six stages, each consisting of activities to be concurrently implemented. ${ }^{152}$ State Parties envisage that the AEC will provide a rallying point for the activities of RECs. Pursuant to the Treaty, the Community is to be established through the co-ordination, harmonization and progressive integration of the activities of RECs. ${ }^{153}$ This arrangement implies that progress by an REC is progress towards the AEC. ${ }^{154}$ I now proceed to discuss each stage and its central focus. The first stage, lasting five years, was meant to strengthen existing RECs and establish new ones in regions where none

\footnotetext{
146. Id. art. 3(b).

147. Id. art. 4(1).

148. Id.

149. Id. art. 4(2)(e).

150. Id. art. 4(2)(i).

151. Id. art. $4(2)(\mathrm{d})$.

152. See id. arts. 6, 88 (elaborting upon the different stages of establishing the AEC).

153. Id. art. $88(1)$.

154. For more on RECs, see infra Part IV.
} 
existed. ${ }^{155}$ The Treaty structured the second stage more or less as a preferential trade agreement. This involved, at the level of each REC, stabilizing tariff and 'non-tariff barriers, ${ }^{156}$ customs duties, ${ }^{157}$ and internal taxes. It involved determining the timetable for the gradual liberalization of regional and intra-community trade and harmonizing customs duties vis-àvis third states. It also involved strengthening sectoral integration, particularly in the fields of trade, agriculture, money and finance, transport and communications, industry and energy, and coordinating and harmonizing the activities of RECs. ${ }^{158}$

The third stage, lasting ten years, involved the establishment of a free trade agreement and a customs union at the level of each REC. ${ }^{159}$ At the end of this stage, no member should levy customs duties on goods originating in one member state and imported into another; same for goods originating from third states that are in circulation in member states but imported from one member to another. ${ }^{160}$ The fourth stage, lasting within a period not exceeding two years, ${ }^{161}$ involved coordinating and harmonizing tariff and non-tariff barriers among the various RECs to ultimately establish a continental customs union (CCU). ${ }^{162}$ The establishment of an African Common Market (ACM) was planned to occur within a four-year period from the end of the fourth stage. ${ }^{163}$ This is the fifth stage. The final stage, lasting five years, entails consolidation and strengthening of ACM structures, including implementation of obligations on free movement of persons and factors of production. It also envisages the establishment of a single domestic market, a Pan African Economic and Monetary Union (PAEM), an African Central Bank (ACB) and currency, and a Pan African Parliament (PAP). ${ }^{164}$

155. See AEC Treaty, supra note 12, art. 6(2)(a) ("Strengthening of existing regional economic communities and ... establishing economic communities in regions where they do not exist....”).

156. Defined as "barriers which hamper trade and which are caused by obstacles other than fiscal obstacles." Id. art. 1(s).

157. Defined as "protective customs duties and charges having equivalent effect, levied on goods for their importation." Id. art. 1(p).

158. See id. arts. 6(2)(b), 30(1).

159. See id. art. $6(2)(\mathrm{c})$.

160. Id. art. 33(1).

161. Id. art. $6(2)(\mathrm{d})$.

162. See id. art. 6(2)(d); see also id. art. 32(2) ("During the fourth stage, regional economic communities shall, in accordance with a programme drawn up by them, eliminate differences between their respective external customs tariffs.").

163. See id. art. 6(2)(e).

164. See id. art. 6(2)(f). A PAP had since been established by the AU, with its seat in South Africa. 
The implementation of the stages was to be concurrent across the states, although the stages followed each other consecutively. ${ }^{165}$ This arrangement was meant to ensure that activities across each stage do not overlap. However, the AEC Treaty stipulated that the transition from one stage to another was subject to the confirmation and approval by the AEC Assembly. The Assembly needed to satisfy itself that the specific objectives for each stage was implemented and all commitments fulfilled. ${ }^{166}$ There was no definite timeline. The AEC Treaty accounted for delays. ${ }^{167}$ Like the LPA, it dealt with each sectoral issue in some detail, most of them requiring the adoption of specific legislative and other measures for their realization. These sectoral issues are broad: food and agriculture, industry, science and technology, energy and natural resources, environment, transport, communication, and tourism, education, training, and culture, and human resources, social affairs, health, and population. ${ }^{168}$

3. A Convoluted Relationship between the AEC and the OAU

The lack of clarity in the institutional relationship between the AEC and the OAU might have contributed to Africa's failure to move the AEC project forward. There were discussions on the complex institutional relationships during the processes leading to the adoption of the AEC Treaty. ${ }^{169}$ In the end, states established the AEC as "an integral part" of the OAU; $;{ }^{170}$ likewise the AEC Treaty and its protocols. ${ }^{171}$ The Treaty even provided that the headquarters of the AEC "shall be one and the same as that of the OAU," 172 a needless tautology. These provisions meant that architects of the AEC did not want it to exist as an independent body. Given this convoluted institutional design, the AEC became whatever the OAU members wanted it to be. It also explains why the AEC Treaty was silent on the international personality of the AEC. The Treaty empowered the OAU Secretary-General, acting in his capacity as the Community's legal representative, to undertake certain actions: enter into contracts, be a party to judicial and other legal proceedings, acquire and dispose movable and immovable property, borrow,

165. Id. art. 6(3).

166. Id. art. 6(4).

167. See id. art. 6(5).

168. See generally id. arts. 46-76 (addressing how African member states act and cooperate in these sectoral areas).

169. Jeggan Senghor, The Treaty Establishing the African Economic Community: An Introductory Essay, 1 AFR. Y.B. INT'L L. 183, 183-85 (1993).

170. AEC Treaty, supra note 12, art. 98(1).

171. Id. art. 99.

172. Id. art. 96. 
and accept donations, bequests and gifts. ${ }^{173}$ But the capacity of the OAU Secretary-General to serve as legal representative of the AEC presupposes the existence of a legal entity to be represented. I therefore submit that the AEC possesses an international personality, notwithstanding anything to the contrary. This conclusion is fortified by a provision in the AEC Treaty permitting the Community to conclude co-operation agreements with third states and to establish relations of co-operation with other international organizations "[i]n the pursuit of its objectives." 174

\section{The AU Act Preserves the AEC Treaty}

The AU Act repeals the OAU Charter but preserves the AEC Treaty. ${ }^{175}$ Clearly, states saw the challenge of economic integration as requiring a longer time horizon than the decolonization struggle which, in winding down the OAU, they effectively declared to have been accomplished. ${ }^{176}$ In the AU Act, they promise to accelerate the process of implementing the AEC Treaty in order to promote Africa's socio-economic development and face more effectively the challenges of globalization. ${ }^{177}$ Many of the objectives and principles in the AU Act reflect those in the AEC Treaty. These include accelerating Africa's political and economic integration, ${ }^{178}$ promoting sustainable development at the economic, social and cultural levels, ${ }^{179}$ and coordinating and harmonizing policies of the various RECs to gradually attain economic integration. ${ }^{180}$ This section examines some of the strides towards keeping the integration vision alive. It also notes the still ill-defined relationship between the AU and AEC.

\section{Strides Toward Integration}

The AU has put the rhetoric of economic integration on the front burner since its inauguration. Its policy organs have adopted legally binding instruments and made some important decisions towards advancing the AEC goals. At its inauguration in 2002, the AU Assembly reiterated that the LPA of 1980 "continue to be the blue print for Africa's integration and

173. Id. arts. 98(2)-(3).

174. Id. arts. 92(1)-(2); cf. id. art. 89 (declaring that the AEC shall cooperate with African continental organizations and may conclude cooperation agreements with them).

175. See AU Act, supra note 14, arts. 33(1)-(2).

176. See UdOMBANA, The AfricAn Union, supra note 15, at 51.

177. AU Act, supra note 14, pmbl.

178. Id. art. 3(c)

179. Id. art. 3(j).

180. Id. art. 3(1). 
development." ${ }^{181}$ In 2004, the Assembly accepted, in principle, the AU Vision and Mission of the AU and the Strategic Plan of its Commission (AUC). It believed that these policy thrusts are consistent with those identified within the framework of the process initiated in Sirte and in the formulation of the NEPAD Programme for the integration of Africa. ${ }^{182}$ The Assembly further institutionalized the Conference of Ministers for Integration in 2006, pending rationalization of the Specialized and Technical Committees (STCs). ${ }^{183}$ In a related decision, the Assembly urged RECs to coordinate and harmonize their policies among themselves and with the AUC in order to accelerate Africa's integration process. ${ }^{184}$

The Assembly made a historic decision at that 2012 Summit, "to devote, in line with conditions to be determined by the [AUC], one of its ordinary sessions to considering development and integration issues." 185 It adopted the first Plan of Action of the Minimum Integration Program ${ }^{186}$ and urged members to speed up the process through concrete actions. First, they should empower regional and continental organizations in specific areas in which consensus has been reached. ${ }^{187}$ Second, they should initiate actions aimed at promoting free mobility. ${ }^{188}$ Third, they should speed up the ratification and effective implementation of relevant legal instruments. The document also

181. The Durban Declaration in Tribute to the Organization of African Unity on the Occasion of the Launching of the African Union, para. 4, Assembly of the African Union, First Ordinary Session, ASS/AU/Decl.2(I) (July 9, 2002) [hereinafter Durban Declaration], https://au.int/sites/default/ files/decisions/9564-assembly_au_dec_1-5_i_e.pdf.

182. Decision on the Vision and Mission of the African Union and Strategic Plan, Programme and Budget of the Commission, para. 1, Assembly of the African Union, Third Ordinary Session, Assembly/AU/Dec.33(III)Rev.1 (July 6, 2004), https://au.int/sites/default/files/decisions/9550assembly en 3031 january 2005 auc third ordinary session.pdf.

183. Decision on the Institutionalization of the Conference of African Ministers in Charge of Integration, para. 3, Assembly of the African Union, Seventh Ordinary Session, Assembly/AU/Dec.113(VII) (July 1, 2006), https://au.int/sites/default/files/decisions/9555assembly_au_dec_111-133_vii_e.pdf.

184. Decision on the Moratorium on the Recognition of Regional Economic Communities (RECs), para. 2, Assembly of the African Union, Seventh Ordinary Session, Assembly/AU/Dec.112(VII) (July 1, 2006), https://au.int/sites/default/files/decisions/9555-assembly_au_dec_111-133_vii_e.pdf; $c f$. Decision on "Integration as a Factor for African Renaissance," para. 5, Assembly of the Union, Eighteenth Ordinary Session, Assembly/AU/Dec.404(XVIII) (Jan. 29, 2012), https://au.int/sites/default/files/ decisions/9649-assembly_au_dec_391___415_xviii_e.pdf (inviting states to join hands to map out more resilient regional and continental integration policies).

185. Decision on African Integration, para. 2, Assembly of the Union, Eighteenth Ordinary Session, Assembly/AU/Dec.392(XVIII) (Jan. 29, 2012), https://au.int/sites/default/files/decisions/9649-assembly _au_dec_391_-_415_xviii_e.pdf.

186. Id. para. 3 .

187. Id. para. 4 .

188. Id. 
emphasized the need for intra-Africa partnerships. ${ }^{189}$ The agenda items of the Assembly summits do not show fidelity to the decision to dedicate one of its summits solely to economic integration issues. The agenda items of its bi-annual summits make this clear, which is to be expected in a continent where any similitude of a stable essence is constantly under threat. Nonetheless, the AU has made integration one of its priority agendas. Agenda 2063 proclaims that "[t]he political unity of Africa will be the culmination of the integration process, which includes the free movement of people and the establishment of continental institutions, leading to full economic integration." 190 In 2019, the Assembly urged all RECs to align their programs and action plans with the continental agenda, including the AEC Treaty, Agenda 2063 and its ten-year implementation plan. ${ }^{191}$

2. Still an Ill-defined Relationship

Like the OAU Charter before it, the AU Act still has not satisfactorily addressed the complex relationship between the AU and the AEC. ${ }^{192}$ The AU Act merely provides that upon its entry into force, the OAU/AEC shall undertake the necessary measures to devolve its assets and liabilities to the AU and all matters relating to it. ${ }^{193}$ In effect, the AU has absorbed the institutional structures of the AEC that existed prior to the adoption of the AU Act. ${ }^{194}$ Since the AU replaces the OAU and the AU Act creates organs similar to those created under the AEC Treaty, it must be assumed-because it is not expressly stated - that those AEC organs have been equally subsumed in the AU's. The vagueness in institutional relationship is a potential source of conflict between the AU Act and the AEC Treaty. A conflict arises where, in a particular case, the provisions of an earlier treaty are incompatible with a later treaty on the same subject, in that they cannot

189. Id.

190. Agenda 2063, supra note 52, para. 23.

191. Niamey Declaration of the First Mid-Year Coordination Meeting Between the AU and Regional Economic Communities (RECS) on the Pursuit of the African Integration Agenda, para. 8, MYCM/Decl.1(I) (July 8, 2019) [hereinafter Niamey Declaration], https://au.int/sites/default/ files/decisions/37635-mycm_decl_1_i_e.pdf.

192. See Richard Frimpong Oppong, The African Union, the African Economic Community and Africa's Regional Economic Communities: Untangling a Complex Web, 18 AFR. J. INT'L \& COMP. L. 92, 102-03 (2010) (noting how there are currently no principles of coordination outlined between the AU and the AEC).

193. AU Act, supra note 14, art. 33(1).

194. See AEC Treaty, supra note 12, arts. 7(1)-(2) (explaining that the AEC Treaty established seven organs: the Assembly, the Council of Ministers, the PAP, the Economic and Social Commission, the Court of Justice, the General Secretariat, and the Specialized Technical Committees; and that these organs were empowered to "perform their duties and act within the limits of the powers conferred on them by [the] ... Treaty"). 
be applied simultaneously. ${ }^{195}$ One of the principles for resolving such conflicts is the rule lex posterior derogat legi priori, meaning that a later treaty supersedes an earlier one. ${ }^{196}$ Architects of the AU Act probably envisage such a conflict, hence the subordination of the AEC Treaty to the Act. ${ }^{197}$ This means that, in the event of a conflict between the two instruments, the AU Act will prevail.

\section{E. So Far, Not Far}

The potential benefits of economic integration has been welldocumented, as the first segment of this paper examined. The LPA and AEC Treaty also manifested initial commitments towards finding Africa's solutions to Africa's problems. The question that begs for an answer is why these benefits have eluded Africa, given decades of integration efforts. The answer is that Africa's idea of integration has been shadowy, blighted by the complex institutional setting under which regional integration schemes have been operating. ${ }^{198}$ The eleven years between the LPA and the AEC Treaty dampened the initial enthusiasm to establish an AEC. ${ }^{199}$ By the time the AEC Treaty was adopted, new RECs had been established, with overlapping mandates. This thwarted the initial plan of the OAU to work with only five RECs. ${ }^{200}$ There has been a near absence of robust institutions to drive integration in Africa. States have been more cautious than courageous with different understandings of their roles in regional institution building. Many do not willingly embrace the integration idea. They have failed to subordinate immediate national political interests to long-term regional economic goals. ${ }^{201}$ They generally would rather retreat to their sovereign bunkers than to submit their economies to supranational oversights for the common good. They prefer a hit-and-run approach rather than adopting concrete and sustained action to implement timelines. Their vagueness and indecision explains the absence of unanimity over the meaning, timing, and sequencing of integration. ${ }^{202}$

195. See Mark E. Villiger, COMMENTARY ON THE 1969 Vienna CONVENTION ON THE LAW OF TREATIES 402 (2009).

196. See VCLT, supra note 30 , art. 30, para. 3 .

197. See AU Act, supra note 14, art. 33, para. 2.

198. Alpha Oumar Konaré \& Abdoulie Janneh, Foreword to U.N. ECON. COMM'N FOR AFR., ASSESSING REGIONAL INTEGRATION IN AFRICA II: RATIONALIZING REGIONAL ECONOMIC Communities, at xiii, U.N. Sales No. E.06.II.K.2 (2006).

199. Karangizi, supra note 9, at 234.

200. Id.

201. See Udombana, A Harmony or a Cacophony?, supra note 64, at 202 (critiquing Africa's failed experiment on economic integration).

202. See Karangizi, supra note 9, at 234. 
Africa's economy remains fragmented. Intra-African trade is low. Trade finance, where it exists, is inadequate. Human capital development is poor. Violent conflicts, vested interests of powerful national governments and other important actors, corruption, and the complexity arising from multiple RECs with overlapping membership and mandate repeatedly derail the AEC vision. Poor infrastructure still hampers Africa's trade and development. Where intra-African railway networks, roads, shipping lines, sea and air transport, and ICT facilities exist, they are either inadequate or problematic or both. Driving on many African roads is neither easy nor cheap, as uniformed armed robbers, called Police, often threaten travelers at checkpoints to extract tributes. It is more competitive to be a trader in Asia, with its efficient infrastructure and customs bureaucracies, than in Africa. ${ }^{203}$ The World Bank's ease of doing business ranking of 190 countries for 2018, benchmarked to June 2017, has no African state among the first top twenty. $^{204}$

Market access is one of the simplest levels of integration, but high tariffs and non-tariff barriers continue to hamper intra-African trade. Several countries rank on the bottom of the ease of doing business index, meaning that the regulatory environment is less conducive to the starting and operation of a local firm. The World Bank's ease of doing business ranking for 2018 has no African state among the top twenty. ${ }^{205}$ Almost all the countries at the bottom are from Africa. ${ }^{206}$ South Africa and Nigeria, two of Africa's leading economies, are ranked at 82 and 145, respectively. ${ }^{207}$ Several of these countries are also on the bottom of the World Bank's ranking on ease of registering properties. ${ }^{208}$ An impenetrable jungle of rules, coupled with overflowing enactments, inefficiency of public administration, and lack of an ethical commitment in the public service evince uncertainties and absence of transparency. Such legal black holes force economic actors to do business in the shadow of legality. ${ }^{209}$ This is Africa's bane, where some antediluvian regulations and unnecessary bureaucracies frustrate business,

203. BoLTON, supra note 138 , at 237.

204. See Ease of Doing Business Rankings, WORLD BANK, http://www.doingbusiness.org/rankings (last visited Oct. 7, 2020).

205. See id. (showing that the closest to the top of the league is Mauritius, ranked 25, followed by Rwanda, ranked 41).

206. See id. (including Somalia at 190, Eritrea at 189, South Sudan at 187, Libya at 185, CAR at $184, \mathrm{DRC}$ at 182, Chad at 180, Congo at 179 , and Guinea-Bissau at 176).

207. See id.

208. See id. (including Nigeria at 179, Zambia at 149, Kenya at 125, Ghana at 119, Swaziland at 115, Lesotho at 109, and South Africa at 107, to sample a few).

209. See Herdegen, supra note 81, at 165 (referencing HeRnANDO DE SOTO, El Otro SENDERO: LA REVOLUCIÓN INFORMAL (1986)). 
elicit corruption, and stymie economic growth. Africa largely operates a black market economy, coupled with a ruling-class interest and a culture of patronage that sees inequality as the natural order of things.

For decades, Africa collectively pledged to remove barriers to the free movement of persons, goods, services, and capital. ${ }^{210}$ But insularity remains the guiding principle in many states. South Africa's immigration policy is a containment strategy rather than a path to economic growth. In an era in which borders are coming down in order to encourage mobility and facilitate trade, South Africa is introducing layers of red tape to the process of moving in and out of the country. ${ }^{211}$ Its Immigration Act, which regulates foreigners' right to admission to, residence in, and departure from South Africa, ${ }^{212}$ is an architecture of exclusion. Most South Africans do not view their country as part of Africa; for them, the continent is a place that begins beyond the country's borders. The xenophobic-induced attacks against other African nationals illustrate South Africa's 'we' versus 'them' bunker mentality. ${ }^{213}$

The challenges that collective Africa identified in the Monrovia Declaration of 1979, which prompted the adoption of the LPA in 1980, the AEC Treaty in 1991, and the AU Act in 2000, remain several decades later. These are market fragmentation, smallness of national economies, narrow export base caused by shallow manufacturing capacity, and over-reliance on the export of primary commodities. Others are lack of export specialization, under-developed industrial bases for increased value chains, and high regulatory and tariff barriers. ${ }^{214}$ Instability and poor macro-economic management still define Africa's landscape. ${ }^{215}$ They hobble the quest for

210. See, e.g., Decision on African Economic Community, para. 5, Assembly of Heads of State and Government, Thirty-Fourth Ordinary Session, AHG/OAU/AEC/Dec.1(II) (June 8, 1998), https://archives.au.int/bitstream/handle/123456789/489/1998\%20AHG\%20Dec\%20124-131\%20\%28X XXIV\%29\%20_E.pdf? sequence $=1 \&$ isAllowed $=y$.

211. Sisonke Msimang, Belonging — Why South Africans Refuse to Let Africa in, AFR. IS A COUNTRY (Apr. 15, 2014), https://africasacountry.com/2014/04/belonging-why-south-africans-refuse-to-let-africa.

212. See generally Immigration Act 13 of 2002 (S. Afr.) (repealing the Aliens Control Act 99 of 1991 (S. Afr.) which was a pillar of the apartheid era).

213. See, e.g., South Africa: How Common Are Xenophobic Attacks?, BBC NEws (Oct. 2, 2019), https://www.bbc.com/news/world-africa-47800718 (reporting on attacks across South Africa since 1994, as monitored by the African Centre for Migration \& Society).

214. Wamkele Keabetswe Mene, Secretary-General H.E., Address at the Official Commissioning and Handing Over of the African Continental Free Trade Area (AfCFTA) (Aug. 17, 2020) [hereinafter Statement by Mene].

215. See, e.g., Decision on the Fourth Report of the Peace and Security Council of the African Union on the Implementation of the African Union Master Roadmap of Practical Steps for Silencing the Guns in Africa by the Year 2020, para. 5, Assembly of the Union, Thirty-Second Ordinary Session, Assembly/AU/Dec.719(XXXII) (Feb. 10, 2019), https://au.int/sites/default/files/decisions/36461assembly_au_dec_713_-_748_xxxii_e.pdf (lamenting persistence of threats to peace and security in Africa). 
sustainable economic and human capacity development in many countries. The maiden indigenous Africa Governance Report, ${ }^{216}$ which the AU Assembly commissioned in $2017^{217}$ and formally considered in $2019,{ }^{218}$ declares that governance has generally improved in Africa, though it acknowledges "least gains . . . in democracy and political governance." 219 That report is an augmented reality that is widely detached from the actual. The truth is that Africa's political culture is still "lacking in discernible and widely acclaimable paradigm that can be publicly perceived as organizing and directing a system of socio-cultural dependencies that inhabit social consciousness and is significant to social change and national development." 220 The AU also regards democratic practices, good governance, the rule of law, human rights protection, and respect for the sanctity of human life as shared values. ${ }^{221}$ Corruption among Africa's political leaders also appears to be a shared value. Many of the leaders, whether in the executive or legislative branch-for those countries pretending to be democratic, not to mention authoritarian states — are pirates in power. They treat their countries as prostrate victims to be ravished in pursuit of vainglory. ${ }^{222}$ The names of persons who demonstrate excellence in leadership and live above board could fit into the back of a postage stamp. The last person who won the Mo Ibrahim Prize for Achievement in African

216. See generally Afr. PeEr Review Mechanism, Africa Governance RePort: Promoting AFRICAN UNION SHARED VALUES (2019) [hereinafter AFRICA GOVERNANCE REPORT 2019] (highlighting trends in governance, instability, and development on the continent).

217. Decision on the Revitalisation of the African Peer Review Mechanism, Assembly of the Union, Twenty-Eighth Ordinary Session, Assembly/AU/Dec.631(XXVIII) (Jan. 30, 2017), https://au.int/sites/ default/files/decisions/32520-sc19553_e_original_-_assembly_decisions_621-641_-_xxviii.pdf.

218. Decision on the State of Governance in Africa, para. 5, Assembly of the Union, Thirty-Second Ordinary Session, Assembly/AU/Dec.720(XXXII) (Feb. 10, 2019), https://au.int/sites/default/files/ decisions/36461-assembly_au_dec_713_-_748_xxxii_e.pdf.

219. AFRICA GOVERNANCE REPORT 2019, supra note 216, para. 8.

220. O.B. Lawuyi, Can this Individual Be Wrong? Reflections on Contemporary African Political Culture, in EXPLORING THE ETHICS OF INDIVIDUALISM AND COMMUNITARIANISM 55 (Enoch Olujide Gbadegesin et al. eds., 2016).

221. Declaration on the Theme of the Summit: Towards Greater Unity and Integration Through Shared Values, pmbl., Assembly of the Union, Sixteenth Ordinary Session, Assembly/AU/Decl.1(XVI) (Jan. 30, 2011) [hereinafter Declaration on Shared Values], https://au.int/sites/default/files/decisions/9645-assembly_en_30_31_january_2011_auc_assembly_ africa.pdf.

222. See generally A Multidimensional Perspective on Corruption in Africa: Wealth, Power, RELIGION AND DEMOCRACY (Sunday Bobai Agang et al. eds., 2019) (demonstrating how anticorruption efforts are key to the development of African states); JIMANZE EGO-ALOWES, CORRUPTION IN AFriCA: Resolution through NeW Diagnosis (2014) (noting the correlation between ignorance and corruption on the African continent); Nsongurua J. Udombana, Fighting Corruption Seriously? Africa's Anti-corruption Convention, 7 SING. J. INT'L \& COMP. L. 447 (2003) (providing an overview of the African Union Convention on Preventing and Combating Corruption). 
Leadership ${ }^{223}$ was former President Ellen Johnson Sirleaf of Liberia, in 2017. ${ }^{224}$ Before her was former President Hifikepunye Pohamba of Namibia, in 2014. ${ }^{225}$ The Prize Committee could not find a fit and proper candidate for the award in years 2009, 2010, 2012, 2013, 2016, 2018, and 2019. ${ }^{226}$

The systemic corruption in Africa has forced many citizens to resign to Nietzsche's nihilism - the philosophy of despair. ${ }^{227}$ The evidence is the endless immigration crisis, where "[t]ens of thousands of young African bodies have been swallowed by the sea or abandoned in the desert, in pursuit of a decent life for which they are prepared to risk everything, because they believe there is no hope at home. They testify to the urgent need to act." $" 228$ Collective Africa has acknowledged "the need for radical transformation at all levels and in all spheres" in order to accelerate development and meet the aspirations of citizens. ${ }^{229}$ But chronic remorse is also an undesirable thing. There are mistakes which humanity has made and repented of so often that there is no excuse for repeating them. Besides, Africa can no longer afford an endless economic experiment. It is against this background of reiterated failure and incessant peril that I now examine the AfCFTA Agreement, adopted to reboot Africa's integration agenda and advance sustainable development.

\section{TOWARDS A NEW DEVELOPMENT PARADIGM: THE AFCFTA AGREEMENT}

The AfCFTA Agreement of 2018 established the Continental Free Trade Area (CFTA) to provide the institutional framework for a code of conduct that reduces tariffs and other barriers to trade and eliminates discrimination in trade relations among states. ${ }^{230}$ It is the latest intervention in a legal conversation that began in 1980 with the adoption of the LPA, extending through 1991 with the adoption of the AEC Treaty, and 2000 with the adoption of the AU Act-a long trek in the quest for sustainable

223. Ibrahim Prize for Achievement in African Leadership, MO IBRAHIM FouND., https://mo.ibrahim.foundation/prize (last visited Oct. 8, 2020).

224. Id.

225. Id.

226. Id.

227. See generally Friedrich NiETzSCHE, ThE WiLl to POWER (1901) (arguing that there is no objective order in the universe except what we give it).

228. H.E. Paul Kagame, The Imperative to Strengthen Our Union: Report on the Proposed Recommendations for the Institutional Reform of the African Union, at 4, AFRICAN UNION [AU] (2017) [hereinafter Kagame Report], https://au.int/sites/default/files/pages/34915-file-report-20institutional20 reform20of20the20au-2.pdf.

229. Agenda 2063, supra note 52, para. 66(b).

230. AfCFTA AGT, supra note 21, art. 2. 
development. The AfCFTA Agreement advances "the Pan African Vision of '[a]n integrated, prosperous and peaceful Africa' enshrined in Agenda 2063." ${ }^{231}$ Its State Parties hope to have the African Common Market (ACM) in place by 2023 , five years earlier than the target deadline set in the AEC Treaty. ${ }^{232}$

The AfCFTA Agreement builds on the respective rights and obligations of states under the AEC Treaty, the AU Act, and, where applicable, the Marrakesh Agreement establishing the WTO. ${ }^{233}$ This preambular provision clearly indicates that the CFTA is not a new institutional architecture. It renovates, reinforces, and refines the structures erected in the LPA and the AEC Treaty. ${ }^{234}$ Its reference to the Marrakesh Agreement also suggests that members may take the WTO acquis into consideration in their trading rights and obligations, provided taking the acquis into consideration does not defeat the overarching objective of the CFTA. ${ }^{235}$ To enhance transparency, the AfCFTA Agreement mandates each of its state parties to promptly and publicly publish its laws, regulations, procedures and administrative rulings of general application, and any other commitments under an international agreement relating to any trade matter covered by the Agreement. ${ }^{236}$ The AU Assembly also stated recently that members wishing to enter into economic partnerships with third parties should inform the Assembly and assure that those partnerships will not undermine the AU Vision of creating one African market. $^{237}$

231. Id. art. 3(a) (emphasis added).

232. Issoufou Mahamadou, Report on the African Continental Free Trade Area (AfCFTA), Assembly of the African Union, Thirty-Second Ordinary Session, Ext/Assembly/AU/2(XII) (Feb. 10, 2019), https://archives.au.int/bitstream/handle/123456789/6542/Assembly\%20AU\%204\%20\%28 XXXII\%29\%20_E.pdf?sequence=1\&isAllowed $=$ y.

233. AfCFTA AGT, supra note 21, pmbl. (emphasis in the original).

234. This context probably explains why the AfCFTA is not fitted with a separate legal personality though, as will be shown later, one of its organs is expressly conferred with personality.

235. Cf. AfCFTA AGT, supra note 21, pmbl. (stating the desire to establish the African Continental Free Trade Area while also building on rights and obligations under the Marrakesh Agreement if applicable.); AEC Treaty, supra note 12, art. 93(1) (permitting Member States to conclude agreements with other parties to the extent such agreements are not incompatible with the provisions of the AEC Treaty).

236. AfCFTA AGT, supra note 21, art. 16(1); cf. AEC Treaty, supra note 12, art. 93(1) (requiring Members States to transmit agreements they conclude to the Secretary-General); Protocol on Trade in Services, supra note 24, art. 5 (requiring each State Party to promptly publish any measures pertaining to or affecting the Protocol as well as international or regional agreements affecting trade in services that they conclude).

237. Decision on the African Continental Free Trade Area, para. 7, Assembly of the Union, ThirtySecond Ordinary Session, Assembly/AU/Dec.714(XXXII) (Feb. 10, 2019) [hereinafter Decision on AFCFTA Feb. 2019], https://au.int/sites/default/files/decisions/36461-assembly_au_dec_713__748_xxxii_e.pdf; $c f$. Decisions on the African Continental Free Trade Area (AfCFTA), Assembly of the Union, Thirty-First Ordinary Session, Assembly/AU/Dec.692(XXXI) (July 1, 2018), 
This part examines the objectives and scope of the CFTA, its underlying principles, and its organic structure. It is intended to reveal, inter alia, its architects' efforts to reconcile Afrocentric development needs with free market principles. The AfCFTA Agreement and its protocols ${ }^{238}$ as well as the AEC Protocol on Free Movement of Persons, Right of Residence, and Rights of Establishment, ${ }^{239}$ are some of the primary sources to be interpreted.

\section{A. Purpose and Scope}

The contemporary economic system is a product of complex legal and institutional designs: international trade, commercial and corporate laws, intellectual property (IP) laws, monetary and financial laws, rules on dispute settlement (including conflict of laws), etcetera. Treaties - agreements in written form by two or more states governed by international law ${ }^{240}$ perform a variety of functions in international relations. These functions include regulation of international trade, aviation, environment, cyberspace, boundaries, investment protection, and shared natural resources. ${ }^{241}$ As a regional trade instrument, the AfCFTA Agreement primarily seeks to regulate and facilitate intra-African trade by creating a single market for goods and services facilitated by free movement of persons, residence and establishment. This section interrogates the purpose of the CFTA and its scope of application.

\section{Purpose of the CFTA}

Every treaty is identified by its object and purpose, and the preamble often aids an understanding of the purpose. ${ }^{242}$ Although the preamble lies outside a treaty's operative part and confers no contractual rights or obligations, it provides an introductory statement about the treaty. It usually

https://au.int/sites/default/files/decisions/36130-assembly_au_dec_690_-_712_xxxi_e.pdf (compiling a record of African initiatives and resolutions on intercontinental cooperation).

238. The Protocol on DSM Rules will be excluded from consideration as it does not have immediate relevance to the focus of this paper.

239. Protocol to the Treaty Establishing the African Economic Community Relating to Free Movement of Persons, Right of Residence and Right of Establishment, adopted Jan. 28, 2018, https://au.int/sites/default/files/treaties/36403-treaty-protocol_on_free_movement_of_persons_in_africa _e.pdf [hereinafter AEC Protocol on Free Movement of Persons] (not yet in force); see also Decision on

the Legal Instruments, Assembly of the Union, Thirtieth Ordinary Session, Assembly/AU/Dec.676(XXX) (Jan. 28, 2018), https://au.int/sites/default/files/decisions/33908assembly_decisions_665_-_689_e.pdf (adopting the protocol establishing the African Economic Community).

240. VCLT, supra note 30, art. 2(1)(a).

241. JAMES CRAWFORD, BROWNLIE'S PRINCIPLES OF PUBliC INTERNATIONAL LAW 367 (8th ed. 2012); Malgosia Fitzmaurice, The Practical Working of the Law of Treaties, in INTERNATIONAL LAW 173 (Malcolm D. Evans ed., 2003).

242. VILLIGER, supra note 195, at 43. 
gives a preliminary explanation of the history of the instrument and the parties' intentions, namely, their motivations for concluding and the values underlying the treaty. It also provides the context for the interpretation of the treaty. ${ }^{243}$ Fitzmaurice asserts that the preamble sometimes reflects independent rules of customary international law and, hence, they are binding in character. ${ }^{244}$

Approaching the AfCFTA Agreement and its protocols from their preambles reveals that the CFTA is driven by a collective aspiration for a continental market with free mobility of persons, capital, goods, and services. Such activities are crucial for deepening economic integration and promoting agricultural development, food security, industrialization, and structural economic transformation. ${ }^{245}$ The CFTA is also driven by a desire to create an environment conducive to private sector development that could boost intra-African trade. ${ }^{246}$ Another motivation is the drive to enhance competitiveness at the industry and enterprise levels by exploiting opportunities for economies of scale, continental market access, and efficient resource allocation. ${ }^{247}$ States also desire to harness the potential and capacities of African services suppliers, particularly at the micro, small, and medium levels, in order to develop regional and global value chains. ${ }^{248}$ They hope to achieve these ambitious goals by establishing "clear, transparent, predictable and mutually-advantageous rules" to govern trade, competition policy, investment, and IP. ${ }^{249}$ They are mindful that a comprehensive rule on trade in goods will deepen economic efficiency and linkages and improve social welfare. By progressively eliminating trade barriers, there will be an increase in trade and investment with greater opportunities for economies of scale for businesses of participating states. ${ }^{250}$ Such rules will also assist in resolving challenges of multiple and overlapping trade regimes in order to achieve policy coherence. ${ }^{251}$

243. See VCLT, supra note 30, art. 31(2) (explaining how the CFTA treaty should be interpretted); Golder v. United Kingdom, App. No. 4451/70, 18 Eur. Comm'n H.R Dec. \& Rep. $16 \S 34$ (1975).

244. Gerald Fitzmaurice, The Law and Procedure of the International Court of Justice 1951-54, 33 BRIT. Y.B. INT’L L. 229 (1957).

245. AfCFTA AGT, supra note 21, pmbl. (referencing Agenda 2063).

246. Protocol on Trade in Goods, supra note 23, pmbl.; Protocol on Trade in Services, supra note 24, pmbl.

247. Protocol on Trade in Goods, supra note 23, pmbl.; Protocol on Trade in Services, supra note 24, pmbl.

248. Protocol on Trade in Services, supra note 24, pmbl.

249. AfCFTA AGT, supra note 21, pmbl.

250. Protocol on Trade in Goods, supra note 23, pmbl.; Protocol on Trade in Services, supra note 24, pmbl.

251. Protocol on Trade in Goods, supra note 23, pmbl.; Protocol on Trade in Services, supra note 24, pmbl. 
Following on these overriding motivations, the operative part of the AfCFTA Agreement sets out some 'General Objectives' and 'Specific Objectives.' The 'General Objectives' category includes creating a liberalized market for goods and services through successive rounds of negotiations, contributing to the movement of capital and natural persons and facilitating investments building on the initiatives and developments in state parties and RECs, laying the foundation for the establishment of a Continental Customs Union (CCU) at a later stage, and promoting industrial development through diversification and regional value chain development, agricultural development and food security. ${ }^{252}$ The 'Specific Objectives' category includes cooperation on investment, IP and competition policy, cooperation on all trade-related areas, and cooperation on customs matters and the implementation of trade facilitation measures. ${ }^{253}$ These and other objectives reveal the broad ends that the CFTA seeks to accomplish. Of these objectives, industrial and agricultural development, food security, and diversification and regional value chain are at the heart of Africa's development agenda. The emphasis placed on them, both in the preambular and operative parts of the AfCFTA Agreement, validates this paper's central thesis that the CFTA is an Afrocentric initiative fashioned to address Africa's development needs.

Agricultural transformation is collective Africa's common goal, understandably because it is a strategic sector for economic revolution, productivity, competitiveness, and innovation. Agriculture and food security have been recurring agenda items in the AU Assembly summits since, at least, 2003, as reflected in its many decisions and declarations. ${ }^{254}$

252. AfCFTA AGT, supra note 21 , art. 3.

253. Id. art. 4 .

254. See, e.g., Declaration on Agriculture and Food Security in Africa, Assembly of the African Union, Second Ordinary Session, Assembly/AU/Decl.7(II) (July 10, 2003), https://au.int/sites/default/files/decisions/9548-assembly_en_10_12 july_2003_auc_the_second_ordinar y_session_0.pdf; Sirte Declaration on the Challenges of Implementing Integrated and Sustainable Development on Agriculture and Water in Africa, Assembly of the African Union, Second Extraordinary Session, Ex/Assembly/AU/Decl.1(II) (Feb. 27, 2004), https://www.tralac.org/documents/resources/ african-union/1540-au-assembly-sirte-declaration-on-the-challenges-of-implementing-integrated-andsustainable-development-in-agriculture-and-water-in-africa-february-2004/file.html; Decision on the Special Summit of the AU on Fertilizers, Assembly of the African Union, Seventh Ordinary Session, Assembly/AU/Dec.117(VII) (July 1, 2007), https://archives.au.int/bitstream/handle/123456789/943/ Assembly\%20AU\%20Dec\%20117\%20\%28VII\%29\%20_E.PDF?sequence=1\&isAllowed=y; Sirte Declaration on Investing in Agriculture for Economic Growth and Food Security, Assembly of the African Union, Thirteenth Ordinary Session, Assembly/AU/Decl.2(XIII)Rev.1 (July 1, 2009), https://au.int/sites/default/files/decisions/9560-assembly_en_1_3_july_2009_auc_thirteenth_ordinary_ session_decisions_declarations_message_congratulations_motion_0.pdf; Declaration on Nutrition Security for Inclusive Economic Growth and Sustainable Development in Africa, Assembly of the Union, Twenty-Third Ordinary Session, Assembly/AU//Decl.4(XXIII) (June 26, 2014), https://au.int/sites/default/files/decisions/9661-assembly_au_dec_517_-_545_xxiii_e.pdf; Decision on 
Notwithstanding the several reiterations of its importance to food security and economic growth, there has been no significant progress in attaining the minimum targets of public investment in agriculture. Meeting such targets will demonstrate Africa's ownership and leadership in achieving set goals. Limited progress in agro-industries and agribusiness development hampers value addition and competitiveness of Africa's products in trade locally, regionally, and internationally. ${ }^{255}$ Africa mainly exports primary products, which attract little foreign exchange earnings because their prices fluctuate according to external market variables. ${ }^{256}$ In consequence, Africa has not been able to meet the nutrition needs of its growing population, let alone create value chains for export and sustainable economic growth. ${ }^{257}$ Hunger exists in abundance despite Africa's limitless natural resources, including land, water, plant, livestock, fisheries and aquaculture, and forestry. In 2018, the AU Assembly acknowledged that the number of those affected by hunger and malnutrition has not decreased over the past few years, and that food security without improved nutrition will not deliver the desired inclusive socio-economic outcomes. $^{258}$ Over 200 million people remain undernourished in $2020 .^{259}$ Since there is no vaccine for hunger, many

Fast Tracking CAADP-Malabo Commitments for Accelerating Agriculture Transformation in Africa Through Biennial Review Mechanism and Africa Agricultural Transformation Scorecard, Assembly of the Union, Thirtieth Ordinary Session, Assembly/AU/Dec.668(XXX) (Jan. 28, 2018), https://au.int/sites/default/files/decisions/33908-assembly_decisions_665_-_689_e.pdf; Decision on the Summit on Food Security in Africa, Abuja, Nigeria, Assembly of the African Union, Eighth Ordinary Session, Assembly/AU/Dec.135(VIII) (2007), https://au.int/sites/default/files/decisions/9556-assembly_ en_29_30_january_2007_auc_the_african_union_eighth_ordinary_session.pdf; Decision on the Continental Scorecard for Nutrition, Assembly of the Union, Thirty-Second Ordinary Session, Assembly/AU/Dec.739(XXXII) (Feb. 10, 2019), https://au.int/sites/default/files/decisions/36461-assem bly_au_dec_713_-_748_xxxii_e.pdf.

255. See Malabo Declaration on Accelerated Agricultural Growth and Transformation for Shared Prosperity and Improved Livelihoods, pmbl., Assembly of the Union, Twenty-Third Ordinary Session, Assembly/AU/ /Decl.1(XXIII) (June 26, 2014) [hereinafter Malabo Declaration], https://au.int/sites/ default/files/decisions/9661-assembly_au_dec_517__545_xxiii_e.pdf (discussing challenges in reaching public investment in agriculture goals and the need to address concerns regarding population malnurishment).

256. Cf. NEPAD FD, supra note 51, para. 156 (discussing the need to improve regulations relating to mining activities to strengthen Africa's exports market).

257. See Nsongurua J. Udombana, Keeping the Promise: Improving Access to Socio-economic Rights in Africa, 18 BUfF. HuM. RTS. L. REV. 135, 172 (2012) [hereinafter Udombana, Keeping the Promise] (discussing the main causes of hunger in Africa).

258. Decision on the African Leaders for Nutrition (ALN) Initiative, para. 2, Assembly of the Union, Thirtieth Ordinary Session, Assembly/AU/Dec.681(XXX) (Jan. 28, 2018) [hereinafter Decision on ALN], https://au.int/sites/default/files/decisions/33908-assembly_decisions_665_-_689_e.pdf.

259. See Development Initiatives, 2020 Global Nutrition Report: ACtion on EQuity to END MALNUTRITION (2020), https://globalnutritionreport.org/documents/566/2020_Global_Nutrition_ Report_2hrssKo.pdf (revealing significant inequalities in nutrition outcomes within countries and populations). 
governments resort to food imports to feed their populations. Part five will explore options towards achieving food security and economic growth through agricultural development.

Regional integration used to be seen more as isolated processes of trade arrangements than as development strategies. With time, they have become approaches to economic development. ${ }^{260}$ They have also grown to serve as frameworks for developing political consensus among their members around regional challenges, among them development, politics, and security. ${ }^{261}$ The cross-cutting linkages between trade and development goals indicate that African RTAs are designed as flexible regimes of cooperation rather than rules requiring scrupulous adherence. ${ }^{262}$ This probably explains why the AfCFTA Agreement nestles in these non-trade objectives such as sustainable socio-economic development, gender equality, and structural transformation of states. ${ }^{263}$ The constitutive treaties of some RECs also aspire towards economic development and improved living standards. The Revised ECOWAS Treaty aims to promote cooperation and integration in West Africa in order to raise the living standards of its peoples, maintain and enhance economic stability, foster relations-among members, and contribute to the progress and development of the continent as a whole. ${ }^{264}$ The ECCAS $^{2}$ Treaty provides that integrating the economies of its members will increase economic self-reliance and promote endogenous and self-sustained development. $^{265}$ The SADC Treaty aims, inter alia, to promote selfsustaining development based on collective self-reliance and interdependence of its members. ${ }^{266}$ The same focus is evident in the AU Act, which aims at raising living standards in Africa through co-operation in all fields of human activity. ${ }^{267}$ This yearning probably inspired the inclusion of three financial institutions - the African Central Bank (ACB), African Monetary Fund (AMF), and African Investment Bank (AIB)—as organs of

260. See Claude AKe, A Political ECONOMy of Africa 168 (1981) (discussing regional integration's impact on modern Africa's economic foundation).

261. GATHII, supra note 115 , at 24.

262. See, e.g., AfCFTA AGT, supra note 21, art. 5(d) (listing flexibility as one of its operating principles).

263. Id. art. 3(f); $c f$. Protocol on Trade in Services, supra note 24, pmbl. (stating the desire to provide "social and welfare-enhancing opportunities" in addition to economic opportunities).

264. Revised Treaty of the Economic Community of West African States, art. 3(1), July 24, 1993, 2373 U.N.T.S. 233 (entered into force Aug. 23, 1995) [hereinafter Revised ECOWAS Treaty].

265. Treaty Establishing the Economic Community of Central African States, art. 4(1)(a), adopted Oct. 18, 1983, 23 I.L.M. 945 (entered into force Dec. 18, 1984) [hereinafter ECCAS Treaty].

266. SADC Treaty, supra note 62, art. 5(1)(d).

267. AU Act, supra note 14, art. 3(k); $c f$. id. art. 3(j) (noting the promotion of "economic, social and cultural" development and "the integration of African economies" as objectives). 
the AU ${ }^{268}$ They will certainly play critical roles towards realizing the goals of the CFTA. The AMF, for example, will be critical in providing loans to states to meet their balance of payment challenges. ${ }^{269}$

In sum, the CFTA seeks to significantly boost intra-Africa trade, improve economies of scale through an integrated market, serve as a catalyst for industrial development, place Africa on a path to exporting value-added products, and improve Africa's competitiveness in global trade. ${ }^{270}$ If diligently pursued, it will enhance cooperation, commit states to reforms, increase bargaining power, and improve human security.

\section{The Scope of Application}

Modern international trade regimes are rapidly extending beyond traditional goods and services ${ }^{271}$ and focusing on IP investment, competition, and social (labor) matters. ${ }^{272}$ Even IP 'rights' ${ }^{273}$ used to be regulated by municipal law but are now tradable commodities. ${ }^{274}$ The AfCFTA Agreement covers both the traditional and contemporary subject-matters: trade in goods, trade in services, investment, IP, and competition policy. ${ }^{275}$ Trade in goods cover lists of negotiated specific tariff concessions and commitments by each state party. Its Protocol sets out the terms, conditions

268. See id. arts. 5(1)(i), 19.

269. African Union [AU], Statute of the African Monetary Fund, art. 2(a), adopted June 27, 2014, https://au.int/sites/default/files/treaties/36417-treaty-0046_-_protocol_on_the_establishment_of_the_afr ican_monetary_fund_e.pdf.

270. See Statement by Mene, supra note 214.

271. The strict division between trade in goods and trade in services are sometimes, for example, in measures involving a service relating to a particular good or a service supplied in conjunction with a particular good. See, e.g., Appellate Body Report, European Communities: Regime for the Importation, Sale and Distribution of Bananas, para. 221, WTO Doc. DS27/AB/R (adopted Sept. 25, 1997).

272. See Marsha A. Echols, Regional Economic Integration, 31 INT'L L. 453 (1997) (discussing the importance of considering regional economic integration when conducting analysis on laws affecting an international transaction).

273. IP is an umbrella term for copyright, trademarks, industrial designs, patents, and other types of 'rights.'

274. See generally Justin Malbon ET AL., The WTO AgreEMENT On TRADE-RELATED AspeCtS OF INTELLECTUAL PROPERTY RIGHTS: A COMMENTARY (2014) (providing a textual analysis of the TRIPS Agreement); WTO: TRADE-RELATED ASPECTS OF INTELLECTUAL PROPERTY Rights (Peter-Tobias Stoll et al. eds., 2008) (providing a comparative analysis commentary on the TRIPS Agreement in relation to other similar international agreements); Thomas Cottier, The Agreement on Trade-Related Aspects of Intellectual Property Rights, in 1 The World Trade Organization: Legal, Economic AND POLITICAL ANALYSIS (P.F. Macrory et al. eds., 2005) (discussing how the TRIPS Agreement evolved from a minor agreement, focusing mainly on border enforcement issues, into a main pillar of the multilateral trading system); CARlos M. Correa, Intellectual Property Rights, THE WTO AND DEVEloping COUNTRIES: THE TRIPS AGREEMENT AND PoliCy OPTIONS (2000) (explaining the main provisions of the TRIPS Agreement and the implications for developing countries in implementing the Agreement through national legislation).

275. AfCFTA AGT, supra note 21, art. 6. 
and qualifications under which goods may be imported under the CFTA. ${ }^{276}$ 'Trade in services,' defined as the supply of service in any sector, ${ }^{277}$ includes the production, distribution, marketing, sale, and delivery of a service. ${ }^{278}$ But it does not cover services supplied in the exercise of governmental authority. ${ }^{279}$ Trade in service is based on four modes of supply of a service. ${ }^{280}$ The first is the supply of service from the territory of one state party to that of another. The second is the supply of service in the territory of a state party to the service consumer of any other party. The third is supply of service by a service supplier of one state party through commercial presence in the territory of any other party. The fourth is supply of service by a service supplier of one state party through presence of natural persons of a state party in the territory of any other party. ${ }^{281}$

The tradeable products under the CFTA are negotiated in phases and in successive rounds to create a liberalized market. ${ }^{282}$ The AU Assembly approved the modalities for negotiations in 2017, before the adoption of the AfCFTA Agreement, with a 90 percent level of ambition. ${ }^{283}$ Phase I negotiations cover trade in goods and trade in services, including 'rules of origin,' custom's cooperation and mutual administrative assistance, trade facilitation, non-tariff barriers, technical barriers to trade, sanitary and phytosanitary measures, transit, and trade remedies. Some of these issues have been finalized, which led to the adoption of the two protocols under focus. The tariff issues are annexed to the Protocol on Trade in Goods and form its integral part. ${ }^{284}$ The AfCFTA Agreement also provides for postadoption negotiations on some outstanding issues, ${ }^{285}$ covering IP, investment, and competition policy. ${ }^{286}$ The AU plans to adopt additional protocols on these sectors in January 2021. It has urged the AU Ministers of Trade to fastback negotiations on them and to submit the draft legal texts

276. Protocol on Trade in Goods, supra note 23, art. 1(i).

277. Protocol on Trade in Services, supra note 24, arts. 1(p), 2(3)(b).

278. Id. art. 1(o).

279. Id. art. 2(3)(b). The Protocol defines "a service supplied in the exercise of governmental authority" as "any service which is supplied neither on a commercial basis, nor in competition with one or more service suppliers." Id. art. 2(3)(c).

280. Id. art. 2(2).

281. Id. art. 1(p).

282. AfCFTA AGT, supra note 21, art. 3(b); cf. Protocol on Trade in Services, supra note 24, art. 18(1) (describing how the successive rounds of negotiation must proceed).

283. Decision on the Continental Free Trade Area, para. 3, Assembly of the Union, Twenty-Ninth Ordinary Session, Assembly/AU/Dec.647(XXIX) (July 3, 2017), https://au.int/sites/default/files/ decisions/37294-assembly_au_dec_642_-_664_xxix_e_1.pdf.

284. Protocol on Trade in Goods, supra note 23, art. 3(2).

285. AfCFTA AGT, supra note 21, art. 7(2).

286. Id. art. 7(1). 
through the Specialised Technical Committee on Justice and Legal Affairs. ${ }^{287}$ The January date appears no longer feasible for the adoption of new protocols, in view of the challenges posed by Covid-19, a pneumonia of unknown cause. ${ }^{288}$

June 2020 was the deadline for finalizing these negotiations under the original plan. ${ }^{289}$ Towards achieving that target, the AU Assembly mandated the CFTA Negotiating Institutions to conclude the outstanding work on Phase I, including rules of origin, for submission in February $2020{ }^{290}$ At the subsequent 33rd Ordinary Session in February 2020, the Assembly directed the AUC to convene the necessary meetings to conclude work on rules of origin, schedules of tariff concessions, and specific commitment on the five priority service sectors. ${ }^{291}$ It also directed the CFTA Council of Ministers and relevant AU policy organs to finalize the CFTA 'Organizational Structure' together with a work program and supplementary budget. ${ }^{292}$ Based on the recommendation of the CFTA Council, the Assembly scheduled an Extraordinary Summit for May 30, 2020 to approve all instruments necessary to meet the start date for trading. ${ }^{293}$ Again Covid-19 has put a hold on the works. The pandemic has also caused major disruptions to global trade and the movement of persons, goods, services, with potentially grave implications on Africa's economy. ${ }^{294}$ In April 2020, the CFTA Secretariat announced the postponement of the CFTA trading start date. ${ }^{295}$ The revised start date of trading is now January $1,2021,{ }^{296}$ which will largely depend on

287. See Decision on AfCFTA Feb. 2019, supra note 237, para. 13(ii).

288. The Covid-19 virus first broke out in Wuhan, China, in late December 2019. The World Health Organization classified it as a pandemic in March 2020. See Dr. Tedros Adhanom Ghebreyesus, WHO Dir.-Gen., Opening Remarks at the Media Briefing on COVID-19 (Mar. 11, 2020).

289. See id. para. 6 .

290. Id. para. 13(ii).

291. Decision on the African Continental Free Trade Area (AfCFTA), para. 10, Assembly of the Union, Thirty-Third Ordinary Session, Assembly/AU/Dec.751(XXXIII) (Feb. 9, 2020) [hereinafter Decision on AfCFTA Feb. 2020], https://au.int/sites/default/files/decisions/38180-assembly_au_dec_ 749-795_xxxiii_e.pdf; see also id. para. 16.

292. Id. para. 11.

293. Id. para. 9 .

294. For an in-depth summary of the general impact of COVID-19 on Africa, see generally U.N. ECON. COMM'N AFR., Policy BRIEF: IMPACT OF COVID-19 In AFriCA (May 20, 2020).

295. See Dike Onwuamaeze, AfCFTA Postpones Implementation of Agreement, THIS DAY (Apr. 29, 2020, 4:31 AM), https:/www.thisdaylive.com/index.php/2020/04/29/afcfta-postpones-implementationof-agreement/. Citing Covid-19, the Secretary-General stated: "I think that's the responsible thing to do. I don't think it would be appropriate when people are dying to be focused on meeting the 1 July deadline. Instead all governments should be allowed to concentrate their efforts on fighting the pandemic and saving lives at home." Id.

296. See Chike Olisah, African Continental Free Trade's First Commercial Deal to Take off January 1, 2021, NAIRAMETRICS (Aug. 16, 2020), https://nairametrics.com/2020/08/16/african-continental-freetrades-first-commercial-deal-to-take-off-january-1-2021. 
Africa's ability to flatten the Covid-19 infection curve, especially as finding a vaccine for the virus is still months away. Virtual meetings will be used to complete the outstanding negotiations. ${ }^{297}$

Contestation is a fact of life, but so is compromise. Thus, whatever the preferred method of negotiating the outstanding issues, the CFTA negotiating parties should show flexibility. The parties should bear in mind Africa's peculiar needs. Negotiations on IP, for example, should be less rigid than the onerous rules under the WTO Agreement on Trade-Related Aspects of Intellectual Property Rights (TRIPS). ${ }^{298}$ The parties should balance the need for adequate protection in the country of destination with the imperative of technology transfer for sustainable development. IP is a social product. A rigid patent protection could pose a serious barrier to accessing life-saving (traditional) medicines, particularly in a continent frequently afflicted with epidemics like HIV/AIDS and tuberculosis (TB). ${ }^{299}$ Ultimately,

States parties thus have a duty to prevent unreasonably high costs for access to essential medicines, plant seeds or other means of food production, or for schoolbooks and learning materials, from undermining the rights of large segments of the population to health, food and education. Moreover, States parties should prevent the use of scientific and technical progress for purposes contrary to human rights and dignity, including the rights to life, health and privacy, e.g. by excluding inventions from patentability whenever their commercialization would jeopardize the full realization of these rights. ${ }^{300}$

Certain products are excluded from liberalization. These are designated as 'Sensitive Products and 'Exclusive List,' based on the following criteria: food security, national security, fiscal revenue, livelihood and industrialization. ${ }^{301}$ These products have fixed percentages -7 percent of total tariff lines for 'Sensitive Products' and a maximum of 3 percent of total tariff lines for 'Exclusive List. ' 302 There is a proviso that products excluded from liberalization should not represent more than 3 percent of tariff lines,

297. See Press Release, African Union Directorate of Information \& Communication, In Wake of Covid-19, African Union to Keep AfCFTA on Track with Digital Technology (Aug. 14, 2020) (on file with author).

298. General Agreement on Tariffs and Trade-Multilateral Trade Negotiations (The Uruguay Round): Agreement on Trade-Related Aspects of Intellectual Property Rights, Including Trade in Counterfeit Goods, Dec. 15, 1993, 33 I.L.M. 81.

299. See generally Holger Hestermeyer, Human Rights And the WTO: The CASE OF PATENTS AND ACCESS TO MEDICINES (2007) (explaining the conflict between human rights law and patent law in the context of access to life-saving medication).

300. Econ. \& Soc. Council, Comm. on Econ., Soc. \& Cultural Rts., General Comment No. 17, para. 3(ii), U.N. Doc. E/C.12/GC/17 (Jan. 12, 2006).

301. Decision on AFCFTA Feb. 2019, supra note 237, para. 3(ii).

302. Id. para. 4 . 
and accounting for not more than 10 percent of the value of imports from other states. $^{303}$

B. Shared Values and Organizing Principles

Collective Africa recognizes democracy, human rights promotion, gender equality, and the rule of law as instrumental values for developing economic cooperation, including international trade. ${ }^{304}$ The preamble to the AfCFTA Agreement embeds these libertarian and egalitarian values; ${ }^{305}$ likewise the AEC Treaty, ${ }^{306}$ the AU Act, ${ }^{307}$ Agenda $2063,{ }^{308}$ and the AEC Protocol on Free Movement of Persons. ${ }^{309}$ These values formed the theme of the AU Assembly's summit in 2011; and in the subsequent Declaration, the AU noted "Africa's rich tradition of solidarity, consensus, national reconciliation and communalism and its contribution to the universal principles of governance, democracy, and human rights." ${ }^{310}$ The Africa Governance Report additionally articulates unity, prosperity, peace, citizen empowerment, and global engagement as common goals that inform Africa's collective decisions and actions. ${ }^{311}$ Clearly, these shared values are means for accelerating Africa's integration agenda, ${ }^{312}$ but their relevance does not have to be established through their direct or indirect contribution to GDP growth. ${ }^{313}$ They could serve as tools for mobilizing Africans to the ideals of Pan-Africanism. ${ }^{314}$ In the specific context of the CFTA, these shared values could help to maintain a healthy balance between the perils of free markets and the demands of social justice. They should therefore inform the AU's common position on trade, environment, security, or any other.

The operative part of the AfCFTA Agreement also incorporates liberal economic principles, such as trade liberalization, factor mobility, the MostFavored-Nations (MFN) Treatment, transparency, flexibility, variable

303. Id.

304. AfCFTA AGT, supra note 21.

305. Id.

306. AEC Treaty, supra note 12, art. 3(g).

307. AU Act, supra note 14, arts. 3(g)-(h), 4(1)-(m).

308. Agenda 2063, supra note 52, para. 28.

309. AEC Protocol on Free Movement of Persons, supra note 239, pmbl.

310. See Declaration on Shared Values, supra note 221, pmbl.

311. AFRICA GOVERNANCE REPORT 2019, supra note 216, para. 2.2.

312. See Declaration on Shared Values, supra note 221, pmbl.

313. Cf. Amartya Sen, DeVelopment as Freedom 5 (1999) (noting that economic opportunities can also be "influenced by the exercise of people's freedoms").

314. Cf. Declaration on Shared Values, supra note 221, para. 1 (declaring a commitment to reinforce the understanding of shared values and promoting them as a means to achieving continental integration). 
geometry, and special provisions respecting least developing members. ${ }^{315}$ These principles largely reflect the WTO framework. ${ }^{316}$ The rest of this section examines some of these free market principles.

\section{A Liberalized Market}

Trade liberalization is the belief that free markets, unrestrained by governments, generally result in the most efficient and socially optimal allocation of resources. ${ }^{317}$ It entails the elimination of restrictions and discrimination that impede the free movement of goods, services, persons, and capital among the integrating states. Liberalization is based on two concepts that are central to neo-classical theories on gains: comparative advantage and economies of scale. ${ }^{318}$ Adam Smith and David Ricardo are credited with laying the intellectual foundations for these concepts, ${ }^{319}$ though Hobbes espoused liberal values before them. ${ }^{320}$ The concept of comparative advantage, also known as 'comparative costs,' posits that a state should produce goods in which it has an advantage over others. Even if a state can make everything cheaper than others, it still benefits from focusing on goods in which its relative, or comparative, advantage is greatest. ${ }^{321}$ That way, it can raise living standards through trade. Smith puts it thus: "If a foreign country can supply us with a commodity cheaper than we ourselves can make it, better buy it of them with some part of the produce of our own industry, employed in a way in which we have some advantage." ${ }^{22}$ The concept of

315. AfCFTA AGT, supra note 21, art. 5.

316. See, e.g., GATT 1994, supra note 65, arts. I-X; cf. GATT 1947, supra note 65, arts. I-IX (discussing how these principles applied in the 1947 version of GATT).

317. See Denis O'Hearn, Tigers and Transnational Corporations: Pathways from the Periphery?, in Critical Development Theory: Contributions to a New Paradigm 117 (Ronaldo Munck \& Denis O’Hearn eds., 1999).

318. See STIGLITZ \& CHARLton, supra note 123, at 6; Zubair IQBAL \& MOHSIN S. KHAN, IMF, TRADE REFORM AND REGIONAL INTEGRATION IN AFRICA (1998); Kyle W. Bagwell et al., It's a Question of Market Access, 96 AM. J. INT'L L. 56, 59 (2002). See generally MiREla KeusChNiGG, COMPARATIVE ADVANTAGE IN INTERNATIONAL TRADE: THEORY AND EVIDENCE (1999) (providing an in-depth analysis of Heckshcher-Ohlin factor proportions theory); Kwok Tong Soo, The Gains from External Scale Economics and Comparative Advantage (Lancaster Univ. Mgmt. Sch., Economics Working Paper Series No. 2013/007, 2013) (discussing possible gains from external scale economies for small countries compared to larger countries through avenues like trade and the development of more specialized production activities).

319. See generally ADAM SMith, I-V AN INQUIRY INTO THE NATURE AND CAUSES OF THE WEALTH OF NATIONS (MetaLibri 2007) (1776) (describing capitalism as an emerging theory); DAVID RICARDO, On the Principles of Political Economies AND TAXation (Dover Publications 2004) (1817) (presenting an early description and overview of the theory of comparative advantage).

320. See Thomas Hobbes, Leviathan 208 (C.B. Macpherson ed., Penguin Books 1985) (1651).

321. See PAUl R. KRUGMAN ET AL., InTERnATIONAL ECONOMICS: THEORY AND POLICY 27 (9th ed. 2014).

322. SMITH, supra note 319 , at 293. 
economies of scale builds on the idea that specialization in the production of goods and services leads to lower (average) costs. It assumes that the cost of tariff reductions in favor of a state is warranted only when a trading partner obtains an offsetting benefit from a reciprocal tariff concession. ${ }^{323}$ The laissez-faire and free trade policies have been built around these ideas. ${ }^{324}$ But Ricardo's idea has been challenged for its lack of empirical support, "its assumptions about the inability of labor and capital to cross borders," and "its willful blindness to the role of slavery and colonialism in shaping the British Empire's comparative advantage." 325

Tariff reduction, such as customs duties and taxes or excise duties and taxes, and the elimination of non-tariff barriers are the principal instruments of trade liberalization. ${ }^{326}$ The AfCFTA Agreement, which embraces trade liberalization, ${ }^{327}$ obliges its members to progressively eliminate all barriers to trade in goods and liberalize trade in services. ${ }^{328}$ The assumption is that such liberalization will boost intra-African trade. ${ }^{329}$ As a means of creating a liberalized market in Africa, the Protocol on Trade in Goods aims to enhance efficiency of customs procedures, trade facilitation and transit, and cooperation in the areas of technical barriers to trade and sanitary and phytosanitary measures. ${ }^{330}$ Like with tariff barriers, the Protocol contains

323. Nsongurua J. Udombana, A Question of Justice: The WTO, Africa, and Countermeasures for Breaches of International Trade Obligations, 38 J. MARSHALL L. REV. 1153, 1165 (2005) [hereinafter Udombana, A Question of Justice]; Gerhard Loibl, International Economic Law, in INTERNATIONAL LAW, supra note 241, at 689, 690 n.1.

324. See Sonia E. Rolland, Development at the World Trade Organization 16 (2012) ("Ricardo's law of comparative advantage was (and still is) the premise used by advocates of trade liberalization and division of labor.").

325. Kombo, supra note 49, at 3.

326. HERDEGEN, supra note 81 , at 66.

327. See AfCFTA AGT, supra note 21, art. 3(b) (listing the establishment of "a liberalised market for goods and services through successive rounds of negotiations" as one of the objectives of the agreement).

328. Id. pmbl., arts. 4(a)-(b); cf. Protocol on Trade in Goods, supra note 23, art. 2(1) (declaring the creation of a "liberalised market for trade in goods" as the "principal objective" of the Protocol); Protocol on Trade in Services, supra note 24, pmbl. (stating the desire to create an integrated services market based on "progessive liberalisation of trade in services").

329. See, e.g., Protocol on Trade in Services, supra note 24, art. 18(3) ("The liberalisation process shall focus on the progressive elimination of the adverse effects of measures on trade in services as a means of providing effective market access with a view to boosting intra-African trade in services.").

330. Protocol on Trade in Goods, supra note 23, arts. 2(2)(c)-(d); see also Schedules of Tariff Concessions, Annex 1, Assembly of the Union, Thirty-First Ordinary Session, Assembly/AU/11(XXXI) (July 1, 2018), https://au.int/sites/default/files/documents/37121-doc-draft_annexes_estbt_of_cfta.pdf; Rules of Origin, Annex 2, Assembly of the Union, Thirty-First Ordinary Session, Assembly/AU/11(XXXI) (July 1, 2018), https://au.int/sites/default/files/documents/37121-doc-draft annexes_estbt_of_cfta.pdf; Customs Co-Operation and Mutual Administrative Assistance, Annex 3, Assembly of the Union, Thirty-First Ordinary Session, Assembly/AU/11(XXXI) (July 1, 2018), https://au.int/sites/default/files/documents/37121-doc-draft_annexes_estbt_of_cfta.pdf; Trade 
schedules on non-tariff barriers, including technical barriers on trade that it seeks to eliminate. ${ }^{331}$

Liberalization under the CFTA must be managed with a focus on social justice. The stakes are higher for Africa than a wholesale liberalization of its markets, especially in the context of global trade. The so-called free market creates a culture that facilitates a sense that the dailyness of life is all there is to it. The market desanctifies place, commercializes time, alters and weakens the concept of the sacred, and creates doubts about the larger purposes which informs daily living. ${ }^{332}$ In our increasingly materialistic world, where almost every area of human experience now passes through the measuring rod of markets, some think that efficiency and profits should trump social justice. ${ }^{333}$ But even great economists, who preoccupied their minds with economic efficiency, still recognized that social solidarity is a core human characteristic. Adam Smith wrote: "How selfish soever man may be supposed, there are evidently some principles in his nature, which interest him in the fortune of others, and render their happiness necessary to him, though he derives nothing from it except the pleasure of seeing it." ${ }^{334}$ Free trade is important, but it must be people-centered and must aim at human welfare. It must give greater voice to the marginalized, including women who often disproportionately bear "the burden of weakened social safety nets." 335 Communitarianism, or Ubuntu philosophy of solidarity and

Facilitation, Annex 4, Assembly of the Union, Thirty-First Ordinary Session, Assembly/AU/11(XXXI) (July 1, 2018), https://au.int/sites/default/files/documents/37121-doc-draft_annexes_estbt_of_cfta.pdf.

331. Id. art. 2(2); see also Non-Tariff Barriers, Annex 5, Assembly of the Union, Thirty-First Ordinary Session, Assembly/AU/11(XXXI) (July 1, 2018), https://au.int/sites/default/files/documents/ 37121-doc-draft_annexes_estbt_of_cfta.pdf; Technical Barriers to Trade, Annex 6, Assembly of the Union, Thirty-First Ordinary Session, Assembly/AU/11(XXXI) (July 1, 2018), https://au.int/sites/default/ files/documents/37121-doc-draft_annexes_estbt_of_cfta.pdf.

332. Robert E. Lane, Autonomy, Felicity, Futility: The Effects of the Market Economy on Political Personality, 40 J. POL. 2, 19-22 (1978).

333. See JACK DONNElly, InTERnAtional Human Rights 160 (1998) (saying a history of market economics can lead to overlooking the flaws of such a system); $c f$. Jack Donnelly, Ethics and International Human Rights, in ETHICS AND INTERNATIONAL AFFAIRS: EXTENT AND LIMITS 153 (Jean-Marc Coicaud \& Daniel Warner eds., 2001) (discussing the benefits of efficient markets in terms of benefiting the collective as opposed to being good for every single individual in society); F. Amalric et al., Transnational Corporations and Human Rights: The Business Implications 1 (CCRS Working Paper Series, Working Paper No. 03/05, 2005) (quoting Milton Friedman, A Friedman Doctrine-The Social Responsibility of Business Is To Increase Its Profits, N.Y. TIMES (Sept. 13, 1970), https:/www.nytimes.com/1970/09/13/archives/a-friedman-doctrine-the-social-responsibility-ofbusiness-is-to.html) (discussing the view that businesses should just be focused on pursuing shareholder value as opposed to enforcing human rights regulations).

334. Adam Smith, The Theory of Moral Sentiments 11 (Knud Haakonssen ed., Cambridge Univ. Press 2002) (1759).

335. Kombo, supra note 49, at 2. 
responsibility, ${ }^{336}$ must drive CFTA's implementation. The 'I-Thou' approach to inter-state and inter-personal relations is the only way Africa can be fully authentic. ${ }^{337}$ Mbiti sums it up in his famous statement: "I am because we are; and since we are, therefore I am." ${ }^{338}$

\section{Non-Discrimination}

Non-discrimination is a central pillar in international economic law. Discrimination connotes-

any advantage, favour, privilege or immunity with respect to a like product, in relation to customs duties and charges of any kind imposed on the importation or exportation of a like product; or in relation to international transfer of payments for exports or imports; or in relation to any rules and formalities connected with the import or export of a product. ${ }^{339}$

The prohibition of discrimination operates on two different levels. The first is the Most-Favored-Nation treatment (MFN) principle. The second is the national treatment principle. Both principles derive from treaty law, meaning that they do not constitute general international law. ${ }^{340}$ They both "serve equal competitive conditions in the market." ${ }^{341}$ I begin with the MFN treatment principle.

The MFN treatment is a relative standard aimed at creating an equal playing field for all trading members. As used in modern commercial treaties, it refers to "[t]he situation in which a state promises . . . to trade with a particular partner on the most favourable tariff terms available for like goods." 342 Aristotle's concept of distributive justice may be used to further

336. See generally JOHANN BROODRYK, UBUNTU: LIFE LESSONS FROM AFRICA (2002) (exposing ubuntu as a worldview to order society); MogOBE B. RAMOSE, AFricAN PHILOSOPHY THROUGH UbunTU (1999) (outlining how concepts such as law and justice can be understood through the philosophy of Ubunto).

337. See generally MARTIN Buber, I AND ThOu (Ronald Gregor Smith trans., T. \& T. Clark 1937) (1923) (presenting a philosophy of personal dialogue).

338. JOHN MBITI, AFRICAN RELIGIONS AND PHILOSOPHY 141 (Heinemann 2d ed. 1990) (1969).

339. ASIF H. QURESHI, INTERNATIONAL ECONOMIC LAW 359-60 (2011).

340. See RUdOlF DOLZER \& CHRISTOPH SCHREUER, PRINCIPLES OF INTERNATIONAL INVESTMENT LAW 206 (2012) (arguing that the Most-Favored-Nation and national treatment principles are not considered parts of customary international law).

341. HERDEGEN, supra note 81, at 66.

342. Most Favoured Nation Treatment (MFN Treatment), OXFORD DICTIONARY OF LAW (Elizabeth Martin \& Jonathan Law eds., 2006); $c f$. UNCTAD, Most-Favored-Nation Treatment, in UNCTAD SERIES ON ISSUES IN INTERNATIONAL INVESTMENT AGREEMENTS II (2010) (providing an overview of Most-Favored-Nation treatment provisions in international investment agreements by specifically discussing the features of such provisions, their functions, how violations of said agreements play out in practice, and policy options for implementation). 
explain the MFN treatment. ${ }^{343}$ Distributive justice demands that 'equals' should be treated equally and 'unequals' should be treated unequally. ${ }^{344}$ Since all states are sovereign and equal, ${ }^{345}$ the MFN demands equal treatment on the international level. A state should extend to all other member states the benefits it grants to a given state's trade or investment relations (or nationals, goods, services, and investments). A member should not, as between other trading members, discriminate in relation to like products originating from member states or in relation to like products destined for different member countries. ${ }^{346}$ The closest analogy to the MFN treatment is the fair and equitable treatment (FET) standard in investment protection. ${ }^{347}$ The FET is infringed by a conduct attributable to a state and harmful to the claimant, "if the conduct is arbitrary, grossly unfair, unjust or idiosyncratic, is discriminatory and exposes the claimant to sectional or racial prejudice, or involves a lack of due process leading to an outcome which offends judicial propriety." 348 The MFN standard does not apply to agreements with thirdparty states which are inextricably linked to a specific bilateral negotiating situation with a particular set of rights and obligations. ${ }^{349}$

To create an equal playing field in intra-African trade, the AfCFTA Agreement enshrines the MFN treatment principle, ${ }^{350}$ while its annexed protocols work out the details. The Protocol on Trade in Services provides: "With respect to any measure covered by this Protocol, each State Party shall, upon entry into force, accord immediately and unconditionally to services and service suppliers of any other State Party treatment no less

343. See Aristotle, The Nicomachean Ethics (Hugh Tredennik ed., J.A.K. Thomson trans., Penguin Books rev. ed. 2004) (c. 384 B.C.E.).

344. See id. at 118-20.

345. See, e.g., U.N. Charter art. 2, \1; AU Act, supra note 14, art. 4(a); AEC Treaty, supra note 12, art. 3(a); S.S. Lotus (Fr. v. Turk.), Judgment, 1927 P.C.I.J. (ser. A) No. 10, at 25 (Sept. 7). Note that formal or juridical equality is not the only criterion of equal treatment. See, e.g., Settlers of German Origin in Poland, Advisory Opinion, 1923 P.C.I.J. (ser. B) No. 6 (Sept. 10); Minority Schools in Albania, Advisory Opinion, 1935 P.C.I.J. (ser. A/B) No. 64, at 4 (Apr. 6); cf. RollAND, supra note 324, at 309 ("Formal equality and formal reciprocity makes for a very Talion-like legal system (an eye for an eye). That legal culture is now becoming a source of inequity.").

346. See QURESHI, supra note 339, at 359-60 (stating that discrimination involves "any advantage, favour, privilege or immunity with respect to a like product" in international trade).

347. See generally RuMANA ISLAM, THE FAIR AND EQUitABle TREATMENT (FET) STANDARD IN INTERNATIONAL INVESTMENT ARBITRATION: DEVELOPING COUNTRIES IN CONTEXT (2018) (examining the interpretation of the FET standard in key arbitral awards affecting host developing countries, while highlighting the variety of interpretation approaches adopted by investment tribunals).

348. Waste Mgmt., Inc. v. United Mexican States, ICSID Case No. ARB(AF)/00/3, Award, ๆ 97 (Apr. 30, 2004) (quoting Loewen Group, Inc. v. U.S., ICSID Case No. ARB(AF)/98/3, Award, ๆ 132 (June 26, 2003), 7 ICSID Rep. 442 (2003)).

349. See Técnicas Medioambientales Tecmed SA v. United Mexican States, ICSID Case No. $\mathrm{ARB}(\mathrm{AF}) / 00 / 2$, Award, ๆ 69 (May 29, 2003).

350. AfCFTA AGT, supra note 21 , art. $5(\mathrm{~g})$. 
favourable than that it accords to like services and service suppliers of any Third Party." 351 Unlike the traditional MFN, the CFTA legal regime is limited in its application. Its MFN treatment depends on similarities of the respective bilateral situations resulting from a comparable negotiating context. The AfCFTA Agreement requires that state parties "accord each other, on a reciprocal basis, preferences that are no less favourable than those given to Third Parties." ${ }^{352}$ A state shall also afford opportunities to other states "to negotiate preferences granted to Third Parties prior to entry into force of this Agreement and such preferences shall be on a reciprocal basis." 353 This provision is intended to preserve the acquis by preventing "a country with a relatively closed economy from gaining additional market access without making concessions in return." 354 Some commentators think that "the lack of a traditional MFN clause in the AfCFTA Agreement" risks creating "a patchwork of rights and obligations that differ across each" state and "that the AfCFTA may not foster intra-African value chains" in a higher degree. $^{355}$

The national treatment principle demands equal treatment in a domestic context. It prohibits discrimination against nationals, goods, services, and investments of other states within the trading area. ${ }^{356}$ This principle will be amplified in the next segment dealing with factor mobility. Suffice to note that the AfCFTA Agreement also enshrines this principle. ${ }^{357}$ The Protocol on Trade in Goods requires its state party to "accord to products imported from other State Parties treatment no less favorable than that accorded to like domestic products of national origin, after the imported products have been

351. Id. art. 4(1).

352. Id. art. 18(1) (emphasis added); cf. Protocol on Trade in Goods, supra note 23, art. 4(1) (requiring State Parties to give "Most-Favoured-Nation Treatment" to one another); Protocol on Trade in Services, supra note 24, art. 4(1) (requiring State Parties to accord "no less favourable" treatment to service and service suppliers of other State Parties than they would accord to any non-State Party).

353. AfCFTA AGT, supra note 21, art. 18(2) (emphasis added); $c f$. Protocol on Trade in Goods, supra note 23, art. 4(3) ("Nothing in this Protocol shall prevent two or more State Parties from extending to one another preferences which aim at achieving the objectives of this Protocol among themselves, provided that such preferences are extended to the other State Parties on a reciprocal basis."); Protocol on Trade in Services, supra note 24, art. 4(3) ("Other State Parties shall be afforded opportunity to negotiate the preferences granted therein on a reciprocal basis.").

354. See Landry Signé \& Colette Van Der Ven, Brookings, Keys to Success for the AFCFTA NEGOTIATIONS 4 (2019).

355. Id. at 5 .

356. See Herdegen, supra note 81 , at 67. See generally Mattia Melloni, The Principle of

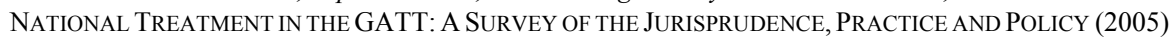
(using law and economics to describe the principle of national treatment in the GATT).

357. AfCFTA AGT, supra note 21 , arts. 5(g)-(h). 
cleared by customs." ${ }^{358}$ The Protocol on Trade in Services is similarly worded. ${ }^{359}$

\section{Factor Mobility}

International trade and investment thrive with the ease of mobility of persons, goods, and services within an integrated area. A sound international trade policy must therefore maintain open borders among the integrating states. ${ }^{360}$ Such a policy not only enhances trade among the parties. It also promotes Foreign Direct Investment (FDI), which is valued for the activity and employment it creates, the incentives it gives to domestic producers to increase their efficiency, and the technology transfers it may generate. ${ }^{361}$ The European Union (EU) remains the gold standard in this respect. Its economic and political integration is unparalleled, a unique venture with no model in history. ${ }^{362}$ The EU establishes an internal market with free movements of persons, goods, services, capital and payments, with the power to harmonize national laws to achieve a functioning internal market. Its successful experiment in areas of free trade, customs, and common markets and the EU's sovereign role in matters such as labour law, consumer regulations, antitrust, and environmental law, ${ }^{363}$ emboldened its members to move towards a monetary union in 2002, with qualified success. Although 'Brexit', a shorthand for Britain's vote to leave the $\mathrm{EU},{ }^{364}$ has cast doubts upon the EU's future as an institution for regional governance, the EU still offers great lessons for Africa.

358. Protocol on Trade in Goods, supra note 23, art. 5; cf. GATT 1947, supra note 65, art. 1 (“[A]ny advantage, favour, privilege or immunity granted by any contracting party to any product originating in or destined for any other country shall be accorded immediately and unconditionally to the like product originating in or destined for the territories of all other contracting parties.").

359. Protocol on Trade in Services, supra note 24, art. 20(1).

360. Cf. Agenda 2063, supra note 52, para. 20 (codifying the aspiration of "seamless borders" among African states).

361. Florence Jaumotte, Foreign Direct Investment and Regional Trade Agreements: The Market Size Effect Revisited 3 (Int'l Monetary Fund, Working Paper No. 04/206, 2004), https://ssrn.com/abstract=879031; cf. Gaston Gohou \& Issouf Soumare, Does Foreign Direct Investment Reduce Poverty in Africa and are There Regional Differences?, 40 WORLD DEV. 75, 75 (2012) (reexamining the relationship between FDI inflows and welfare or poverty reduction in Africa).

362. See Patrick R. Hugg, Cyprus in Europe: Seizing the Momentum of Nice, 34 VAND. J. TRANSNAT'L L. 1293, 1339 (2001) (describing the European Union as a "new political form of government").

363. See John Alan Cohan, Sovereignty in a Postsovereign World, 18 FLA. J. INT’L L. 907, 940 (2006) (discussing the powers and organization of the European Union).

364. See Anushka Asthana et al., UK Votes to Leave EU After Dramatic Night Divides Nation, GuARDiAN (June 24, 2016, 2:51 PM), https://www.theguardian.com/politics/2016/jun/24/britain-votesfor-brexit-eu-referendum-david-cameron (referring to Britain's vote to leave the European Union as "Brexit"). 
The AU's commitment to the free mobility of persons, goods, and services is an enduring dedication to the Pan-Africanism vision of economic integration. ${ }^{365}$ Consequently, the AfCFTA Agreement establishes a single market for goods and services that is facilitated by the free movement of persons. ${ }^{366}$ The Agreement evinces an intention to build on the obligations of AU members in the AEC Protocol on Free Movement of Persons. ${ }^{367}$ Indeed, the Protocol was adopted in the course of the CFTA negotiation, meaning that the latter anticipated the former. It defines 'free movement of persons' as "the right of nationals of a Member State to enter move freely and, reside in another Member State in accordance with the laws of the host Member State and to exit the host Member State in accordance with the laws and procedures for exiting that Member State." 368 Its state parties recognize that free mobility will facilitate the establishment of the CFTA. ${ }^{369}$ It will enhance science, technology, education, and research, foster tourism, and facilitate intra-African trade ${ }^{370}$ It will promote mobility of labor, create employment, and improve living standards of Africans. Finally, it will facilitate the mobilization and utilization of Africa's "human and material resources to achieve self-reliant development." ${ }^{\text {371 }}$

Free mobility is based on principles of non-discrimination and transparency. ${ }^{372}$ Thus, the Protocol prohibits a state from discriminating against nationals of another member state entering, residing or established in its territory, on the basis of their nationality, race, ethnic group, color, sex, language, religion, political or any other opinion, national and social origin, fortune, birth or other status. ${ }^{373}$ It accords equal protection to a citizen of another state party entering, residing or established in a host state party. Of course, such entry, stay or establishment must be in accordance with the relevant national laws and policies of the host state. ${ }^{374}$ The Protocol falls into the category of treaties that seek to create and maintain certain standards of treatment of aliens and other groups, which usually refer to a national law as

365. See AEC Protocol on Free Movement of Persons, supra note 239, pmbl. (declaring commitment to free movement and African economic unity).

366. AfCFTA AGT, supra note 21, art. 3(b).

367. Id.

368. Id. art. 1.

369. See id. pmbl. ("[T]he free movement of persons, capital, goods and services ... are crucial for deepening economic integration ....").

370. AEC Protocol on Free Movement of Persons, supra note 239, pmbl.

371. Id.

372. Id. art. 3 .

373. Id. art. 4(1).

374. Id. art. 4(3); cf. CRAWFORD, supra note 241, at 612 (explaining how the Universal Declaration of Human Rights exemplifies an informal prescription that is given legal significance by actions of authoritative decision-makers). 
a method of describing the status to be created and protected. ${ }^{375}$ The use of the word 'nationals' presumes persons having that status under the internal law of the parties. ${ }^{376}$ Under the Protocol, for any entry and stay not exceeding 90 days, a visa will not be required. A national wishing to stay beyond 90 days will seek an extension in accordance with the procedures established by the host state. ${ }^{377}$ The right of entry and residence accorded to nationals of other states extends to their spouses and dependents, again in accordance with the laws of the host state. ${ }^{378}$ The Protocol also guarantees to nationals of member states the right of establishment, ${ }^{379}$ which includes the right to set up in the territory of the host state: "(a) business, trade, profession, vocation; or (b) an economic activity as a self-employed person." 380 These provisions, together with those envisaging an African Passport, ${ }^{381}$ suggest an eventual move towards a Community citizenship, without prejudice to citizenship based on nationality.

The free mobility under the Protocol is to be progressively achieved in three phases, ${ }^{382}$ but it does not affect more favorable provisions in national, regional, or continental instruments. It also does not prevent the accelerated implementation of any phase by a REC or sub-region. ${ }^{383}$ Although the AfCFTA Agreement subordinates all other regional agreements to $\mathrm{it}^{384}$ presumably to ensure that other trading arrangements do not negate the CFTA's objectives - it provides that state parties to other RECs, RTAs, and custom unions that have attained higher levels of regional integration among themselves should maintain such levels. ${ }^{385}$ This provision implicitly acknowledges the progress that some RECs have achieved towards establishing a common market. The ECOWAS Protocol Relating to Free Movement of Persons, Residence and Establishment, ${ }^{386}$ for example, spells

375. See Jurisdiction of the Courts of Danzig, Advisory Opinion, 1928 P.C.I.J. (ser. B) No. 15, para. 64-66 (Mar. 3); Interpretation of the Statute of the Memel Territory, Judgment, 1932 P.C.I.J. (ser. A/B) No. 49, at 45-47 (Aug. 11).

376. CRAWFORD, supra note 241 , at 54 .

377. AEC Protocol on Free Movement of Persons, supra note 239, art. 6.

378. Id. arts. 16(1)-(2). The Protocol mandates its State Parties to "gradually implement favorable policies and laws on residence for nationals of other Member States.” Id. art. 16(3).

379. Id. art. 17(1).

380. Id. art. 17(2).

381. See id. art. 10(1) (obliging States Parties to adopt a travel document called an "African Passport" and to work with the AUC to facilitate the processes towards its issuance to their citizens).

382. Id. art. 5(1).

383. Id. art. 5(3).

384. AfCFTA AGT, supra note 21, art. 19(1).

385. Id. art. 19(2).

386. See, e.g., Protocol Relating to Free Movement of Persons, Residence, and Establishment, May 29, 1979, 1906 U.N.T.S. 32496 [hereinafter ECOWAS Protocol Relating to Free Movement of Persons]. 
out the various stages to be undertaken to accomplish complete freedom of movement, et cetera. This principle could be extended to the whole continent if the political will exists. ${ }^{387}$ The sacrifice is not as great as it seems. To facilitate the realization of the phases, CFTA organs should work together to adopt policy measures that will reduce formalities to the bare essentials to make free mobility and the right of residence and establishment within the trading area easier. There should be measures that limit the scope of refusing entry or terminating the right of residence. They should also adopt a model driving license, including driver's tests and medical standards, to facilitate road travels within the Community. Better still, there could be a policy decision requiring that licenses issued by one member state should be recognized by others. ${ }^{388}$

\section{Special and Differential Treatment (SDT)}

Special and differential treatment is one instance where the principle of sovereign equality of states is sidelined to accommodate extraneous factors. Such factors include divergences in levels of development and unequal capacities to tackle certain economic problems. ${ }^{389}$ As an exception to MFN treatment, the principle recognizes the differential burdens of disciplines in trade relations. ${ }^{390}$ The SDT has been an important part of global trade since the inception of the Generalized System of Preferences (GSP) in 1968. Although it initially focused on creating development opportunities in developing countries, it later shifted towards bridging the gap between the trade liberalization expectations of the Uruguay Round and the actual capabilities of developing country members. ${ }^{391}$ The WTO regime allows waivers of members' obligations under the GSP schemes. ${ }^{392}$ It accords particular privileges to states that the UN Conference on Trade and Development (UNCTAD) classifies as Least Developed Countries

387. Kagame Report, supra note 228, at 5 .

388. Cf. Council Directive 91/439, 1991 O.J. (L 237) 1 (EC) (as amended) (discussing the community driving license model and the need for the licenses to be mutually recognized by member states).

389. Phillipe Cullet, Differential Treatment in International Law: Towards a New Paradigm of Inter-State Relations, 10 EUR. J. INT'L L. 549, 551 (1999).

390. See generally Kevin Kennedy, Special and Differential Treatment of Developing Countries, in 1 The World Trade Organization: Legal, Economic and Political ANALYsis 1523 (Patrick F.J. Macrory et al. eds., 2005) (outlining special and differential treatment of developing countries in the GATT-WTO system).

391. See RoLLAND, supra note 324, at 110.

392. GATT 1994, supra note 65, art. XXIV. 
(LDCs) ${ }^{393}$ The scheme offers them non-reciprocal preferences for goods originating from their territory. It reduces tariff rates on their exports to below those under the MFN treatment. ${ }^{394}$ Differential treatment could also be based on considerations other than levels of economic development, such as the share of international trade, resources under a state's territorial sovereignty, and geographic location. ${ }^{395}$ It could also take forms other than trade concessions; for example, some agreements offer technical and financial support to personnel of LDCs to participate in international meetings. ${ }^{396}$

The CFTA regime enshrines the SDT principle. It recognizes that there are different levels of development among African states and that flexibility is needed to assist those with special needs. ${ }^{397}$ It permits trade preferences in favor of such states. The Protocol on Trade in Goods provides:

In conformity with the objective of the AfCFTA in ensuring comprehensive and mutually beneficial trade in goods, State Parties shall, provide flexibilities to other State Parties at different levels of economic development or that have individual specificities as recognised by other State Parties. These flexibilities shall include, among others, special consideration and an additional transition period in the implementation of this Agreement, on a case by case basis. ${ }^{398}$

The SDT principle mirrors Africa's shared value of solidarity. It advances one of the aspirations in the AEC Treaty, which is the necessity of sharing the advantages of cooperation among states in an equitable and just manner to promote balanced development in all parts of Africa. ${ }^{399}$ The principle should make it possible for bigger African economies to provide enabling clauses in their bilateral and sub-regional undertakings in favor of their smaller counterparts. As an illustration, the CFTA Assembly recently approved a transitional period of five years or less for countries requiring flexibility before the start of liberalization for Sensitive Products so that

393. UN List of Least Developed Countries, UNCDP [hereinafter UN List of LDCs], https://www.un.org/development/desa/dpad/wp-content/uploads/sites/45/publication/ldc_list.pdf (last visited Oct. 8, 2020).

394. See Marrakesh AGT, supra note 28, art. IX(3) (permitting waivers of obligations imposed by Articles I(1) and XIII(1)-(2) of GATT 1994). See generally Uché Ewelukwa, Special and Differential Treatment in International Trade Law: A Concept in Search of Content, 79 N.D. L. REV. 831 (2003) (discussing how flexibilities in tariff structures could lead to promoting the establishment of a particular industry).

395. Cullet, supra note 389 , at 552.

396. See, e.g., Instrument for the Establishment of the Restructured Global Environment Facility, art. 19(3), adopted July 7, 1994, 33 I.L.M. 1283.

397. Protocol on Trade in Goods, supra note 23, pmbl.

398. Id. art. 6.

399. AEC Treaty, supra note 12, pmbl. 
applicable fixed tariffs for these products could be maintained. ${ }^{400}$ Such tariffs are to be eliminated after " 10 years for developing countries and 13 for the least developed countries." 401 The potential obstacle to the effective operation of the SDT principle in the CFTA is that the bigger economies could use domestic measures to build concrete walls of sovereignty around themselves, which will not permit mutual support to penetrate their borders. The AU members must "tear down these walls," in the spirit of their shared values, in order to deepen cooperation and assist each other advance equitable development.

A prior impact assessment will be necessary to ensure that the proposed SDT will be effective. This should be done before the CFTA becomes operational. The jury is still out on the impact of preferential trade on LDCs' economies. ${ }^{402}$ Africa has enjoyed historically different forms of SDT, a prominent example being the African Growth and Opportunity Act (AGOA). The Bush Administration enacted the Act as part of the Trade and Development Act of $2000 .{ }^{403}$ The AGOA focuses on Sub-Saharan Africa (SSA). It allows certain goods-especially textiles-from specified countries to have quota-free and duty-free entry into the U.S. ${ }^{404}$ Studies show that Africa's exports to the U.S. under the AGOA have remained relatively flat since the preferential trade regime began. ${ }^{405}$ SSA remains a geography of poverty. Many states remain on the UNCTAD's LDC list years after enjoying such generous concessions. Thirty-three of the 47 countries currently ranked as LDCs are from Africa. ${ }^{406}$ Only three African states have graduated from the list: Botswana in 1994, Cape Verde in 2007, and Equatorial Guinea in 2017. ${ }^{407}$ LDCs' total share of global exports for 2017 was 0.96 percent. ${ }^{408}$

400. See, e.g., Decision on AFCFTA Feb. 2019, supra note 237, para. 5.

401. Id. (emphasis added).

402. Bernard Hoekman, Operationalizing the Concept of Policy Space in the WTO: Beyond Special and Differential Treatment, 8 J. INT'L ECON. L. 405, 407-10 (2005).

403. African Growth and Opportunity Act, 19 U.S.C. § 3702(1), (4)-(5) (2000).

404. UNCTAD, Handbook on the Scheme of the United States of America: Including Features of the African Growth and Opportunities Act (AGOA) Programme, at 18, U.N. Doc. INT/97/A06 (May 2003).

405. See Davis, supra note 94, at 377 (evaluating the extent to which the AGOA increased imports from eligible states to the U.S. from 2001 to 2015). Petroleum alone accounted for 65 percent or more of U.S. annual imports from the eligible countries. $I d$.

406. UN List of LDCs, supra note 393.

407. Id.

408. UNCTAD, HANDBook of Statistics, at 15, U.N. Doc. TD/STAT. 43, U.N. Sales No. E.19.II.D.1 (2018). 
The main obstacles to successful SDTs are structural rather than legal. ${ }^{409}$ Africa has not fully utilized preferential trade arrangements due to capacity constraints and market access requirements, such as rules of origins $^{410}$ and product standards. Many states are unable to satisfy market access requirements. Consequently, a few products that are economically important for Africa are ineligible for export to the U.S. under the AGOA. ${ }^{411}$ Most states largely rely on a handful of primary products for much of their foreign trade. Many of the unprocessed products that the LDCs export to rich industrialized markets are of little interest to neighboring states with similar economic profiles. Why should "State A" buy a product from "State B" when it has it in its backyard? There may be more opportunities for trade if these states could produce different goods or add real value to their primary products; otherwise, SDT provisions in trade agreements will remain ineffective.

\section{The CFTA Organs}

Effective institutional support is a sine qua non to the successful implementation of regional trade agreements. In recognition of this imperative, the AfCFTA Agreement provides for four organs with multi-task functions over the CFTA. ${ }^{412}$ These organs are the Assembly, the Council of Ministers, the Committee of Senior Trade Officials (CSTO), and the Secretariat. ${ }^{413}$ All four organs are agents of the CFTA, though each will exercise its own will. For example, although the Assembly members retain their international personalities qua states, their acts qua organ are attributable to the CFTA. ${ }^{414}$ Of course, the reverse is not the case. ${ }^{415}$ In this section, I interrogate two of these four organs - the Assembly and the Secretariat - due to space constraints. The Assembly is the legislative and policy organ. The Secretariat is the administrative organ. I will also examine how they will, or should, relate with each other.

409. ROLLAND, supra note 324 , at 256.

410. Rules of origin permit states to determine the "nationality' of a given product by distinguishing between its different foreign sources. John Coyle, Rules of Origin as Instruments of Foreign Economic Policy: An Analysis of the Integrated Sourcing Initiative in the U.S.-Singapore Free Trade Agreement, 29 YALE J. INT'L L. 545, 548 (2004).

411. Davis, supra note 94 , at 379.

412. AfCFTA AGT, supra note 21, arts. 4(g), 9.

413. Id.

414. Cf. Case C-327/91, France v. Comm'n, 1994 E.C.R. I-3666, at I-3674 (holding that an agreement concluded by the European Commission would bind the European Council as a whole).

415. Some commentators think that this 'distinct will' theory is a fiction since the organization, in practice, is little more than a tool in the hands of the members. JAN KLABBERS, AN INTRODUCTION TO INTERNATIONAL INSTITUTIONAL LAW 11-12 (2d ed. 2009). The history of regional governance in Africa, especially in relation to the AEC, appears to validate this observation. Id. 
1. The Assembly

The Assembly is "the highest decision-making organ" of the CFTA. ${ }^{416}$ This is merely a play on words because it is the same "supreme organ" of the AU created under the AU Act ${ }^{417}$ that is designated as the CFTA Assembly. Both the AU Act and AfCFTA Agreement define 'Assembly' as 'the Assembly of Heads of State and Government of the African Union." 418 Unlike the AEC Treaty, which created an autonomous AEC Assembly apart from the OAU Assembly, ${ }^{419}$ the CFTA has no independent supreme policy organ. The AU Assembly is the default organ that will oversee the CFTA ${ }^{420}$ and provide strategic guidance and action plans for boosting intra-African trade. ${ }^{421}$ The fusion of the supreme policy organ of the CFTA with that of the AU is irregular. It creates a situation in which third states, those yet to ratify the AfCFTA Agreement, will participate in deliberations and decide on matters affecting the CFTA. The AU Assembly was created by a separate treaty - the AU Act. Its functions and powers are expressly defined by the treaty creating it. ${ }^{422}$ About half of the states that constitute the AU Assembly are not parties to the AfCFTA Agreement. Only 28 states have ratified the Agreement, representing 51 percent of the 55 AU members. ${ }^{423}$ Twenty-six states are yet to ratify the AfCFTA Agreement, representing 48 percent of AU membership. ${ }^{424}$ The extant AU Assembly Rules, ${ }^{425}$ elaborated pursuant to the AU Act, ${ }^{426}$ governs AU Assembly deliberations. They will also, by necessary implication, apply when the Assembly deliberates on the CFTA. Indeed, the AU Rules have governed the Assembly's deliberations since the AfCFTA Agreement came into force. The Agreement contains no provision on the rules of its Assembly. The quorum for the sessions of the Assembly

\footnotetext{
416. AfCFTA AGT, supra note 21, art. 10(1).

417. AU Act, supra note 14, arts. 5(1)(a), 6(2).

418. Id. art. 1; AfCFTA AGT, supra note 21, art. 1.

419. AEC Treaty, supra note 12, art. 7(1).

420. AfCFTA AGT, supra note 21, art. 10.

421. Id. art. 10(1).

422. AU Act, supra note 14, art. 9.
}

423. AfCFTA, Ratification Status, supra note 34. By comparison, the AEC Treaty currently has 50 parties, excluding Congo, Equatorial Guinea, Madagascar, Somalia, and South Sudan. African Union [AU], List of Countries Which Have Signed, Ratified/Acceded to the Treaty Establishing the African Economic Community (Dec. 15, 2017), https://au.int/sites/default/files/treaties/37636-sl-treaty_ establishing_the_african_economic_community.pdf.

424. Id.

425. African Union [AU], Rules of Procedure of the Assembly of the Union [hereinafter $A U$ Assembly Rules], https://archives.au.int/bitstream/handle/123456789/6448/Rules\%20of\%20Proce dure $\% 20$ of $\% 20$ the $\% 20$ Assembly $\% 2$ c $\% 20$ Executive $\% 20$ Council $\% 2 c \% 20$ PRC $\% 20 \% 26 \% 20$ Statutes $\% 2$ 0of $\% 20$ the $\% 20$ Commission $\% 20$ E.Pdf?sequence=1\&isAllowed=y (as amended).

426. AU Act, supra note 14, art. 8. 
under the AU Rules prescribe is two-thirds of total AU membership, ${ }^{427}$ which is 37 states. This means that the Assembly will need at least nine additional states beyond the current 28 CFTA members to form a quorum for any proposed deliberation and decision on the CFTA.

One of the fundamental principles of treaty law is that a treaty is only binding on the parties to it. ${ }^{428}$ The maxim is pacta tertiis nec nocent nec prosunt. But the AfCFTA Agreement has created an odd situation where third states will participate in deliberations and adopt binding decisions on the CFTA, with possible sanctions for noncompliance. ${ }^{429}$ Yet such decisions will not bind those third states which participate in their making. The AU Assembly has already taken many decisions on the CFTA since the AfCFTA Agreement went into force, as discussed in different parts of this paper. I submit that it is an anomaly for third states to deliberate and decide on matters on which they are not bound. If the AU intended the CFTA to be an integral part of its existing institutional infrastructure, it should have dispensed with the ratification requirement. It should have simply provided for automatic entry into force of the AfCFTA Agreement upon its adoption. Having chosen ratification as the mode by which states agree to be bound, ${ }^{430}$ international law demands that only the ratifying states should bear rights and obligations under the AfCFTA Agreement. ${ }^{431}$ A supplementary protocol is needed to rectify this oddity.

The AfCFTA Agreement empowers the Assembly to interpret its provisions. ${ }^{432}$ This is in consonance with international law, which allows states and other subjects to interpret their legal obligations themselves. This is based on the rule that the main interpreters of legal texts are the parties bound by the legal rules. ${ }^{433}$ Self-interpretation is often the starting and ending point. Unlike municipal systems, where a judge can be seized to settle a

427. AU Assembly Rules, supra note 425, Annex 1, r.6.

428. VCLT, supra note 30 , art. 34 . Where a treaty codifies customary international law, then third States are bound not under the treaty but by the obligations that arise under customary law, though the substance of obligations may be the same. See Military and Paramilitary Activties in and Against Nicaragua (Nicar. v. U.S.), Judgment, 1986 I.C.J. 14 (June 27); North Sea Continental Shelf Cases (Ger. v. Den.), Judgment, 1969 I.C.J. 3 (Feb. 20).

429. AU Act, supra note 14, art. 23(2).

430. VCLT, supra note 30, art. 14(1) ("The consent of a State to be bound by a treaty is expressed by ratification when $(a)$ the treaty provides for such consent to be expressed by means of ratification.").

431. Id.

432. AfCFTA AGT, supra note 21, arts. 10(1)-(2); AU Act, supra note 14, art. 26. One can assume that other CFTA organs will also have the power to interpret their jurisdictions, though the AfCFTA Agreement has not expressly conferred such power on them. Id.

433. KolB, supra note 31, at 129 (emphasis in the original) (referencing Pierre Klein, Les prétentions des etats à la mise en oeuvre unilatérale du droit international, 43 REVUE BELGE DE DROIT INT'L [R.B.D.I.] 141 (2010) (Belg.)). 
matter with a binding decision, international judicial bodies have no mandatory competence. Their jurisdiction rests upon acceptance by the states involved in a given dispute. The AfCFTA Agreement, however, requires the Assembly to take decisions on substantive issues by consensus. $^{434}$ A simple majority of states eligible to vote is needed on questions of procedure, including whether or not a question is one of procedure. $^{435}$

\section{The Secretariat}

The effective functioning of the CFTA, to a large extent, will depend on its Secretariat. If the execution of policies or decisions of the CFTA are left to members or the policy organ only, without some forms of assistance, its norms will likely remain on paper. ${ }^{436}$ The Secretariat will serve as the CFTA's administrative arm and clearing house. The Assembly is empowered to establish the Secretariat, decide on its nature and location, and approve its structure. ${ }^{437}$ But it is the CFTA Council, rather than the Assembly, that is empowered to determine the roles and responsibilities of the Secretariat. ${ }^{438}$ This arrangement is odd; one would think that the establishing organ, in this case the Assembly, should determine the responsibilities of the Secretariat. Meanwhile, the Secretariat is fitted with international legal personality. ${ }^{439}$ It will be subject to obligations under international law. It will have, in appropriate cases, capacity to enter into agreements that create rights and duties. It will have locus standi to enforce rights under international law. And it may be able to claim immunity from jurisdiction in particular legal proceedings. ${ }^{440}$ It is not clear why personality is conferred on the Secretariat rather than the CFTA itself. It appears that the states intend the CFTA to function under the shadows of the AU rather than independent of it. Regardless, it stands to reason that the conferment of international personality on the Secretariat implies that the CFTA possesses a similar personality. The organ of an institution cannot exercise legal powers that are denied to the principal institution. Besides, the Secretariat

434. AfCFTA AGT, supra note 21, arts. 9, 14(1). The CSTO is required to refer "matters on which it has failed to reach consensus" to the Council for consideration; and if the Council cannot reach consensus, it shall refer such matters to the Assembly. Id. art. 14(2).

435. Id. arts. 14(3)-(4).

436. SANDS, supra note 45 , at 302.

437. AfCFTA AGT, supra note 21, art. 13(1).

438. Id. art. 13(6).

439. Id. art. 13(3).

440. $C f$. JOHN O'Brien, INTERNATIONAL LAW 138 (2001) (discussing how internanationl entities may have legal personalities that afford them various abilities, one of which being the ability to claim immunity "from jurisdiction in particular legal proceedings"). 
cannot be an actor on its own. ${ }^{441}$ Whatever it does will be attributed to the CFTA.

The AfCFTA Agreement originally authorized the AUC to serve as an interim Secretariat pending the formal establishment and operationalization of the CFTA Secretariat. ${ }^{442}$ This provision is now redundant. The AU Assembly decided at its 12th Extraordinary Session in July 2019 that Ghana will host the CFTA Secretariat. ${ }^{443}$ It mandated the AUC to collaborate with the Government of Ghana to finalize the host-country agreement and facilitate "the expeditious transfer of the interim CFTA Secretariat to the host-country with a view to accelerating the establishment of the Permanent Secretariat by February 2020." "444 Ghana is a historic trading center in gold, cocoa, and timber and the guardian of Africa's collective memory. ${ }^{445}$ Its choice as the Secretariat will transform this relatively peaceful and stable West African country into a destination of some sorts for states and other entities that will engage the CFTA Secretariat. In making that choice, the AU might have considered Ghana's political stability and good governance, relative security, and its early ratification of the AfCFTA Agreement. ${ }^{446}$ The choice of Ghana for the seat of the CFTA is also a fitting tribute to Kwame Nkrumah, Ghana's first President and foremost Pan-Africanist, who spent his life advancing the political and economic integration of Africa and nurtured the intellectual and philosophical foundations of Pan-Africanism. ${ }^{447}$ One good turn deserves another.

The Secretariat was expected to start functioning on March 31, 2020. ${ }^{448}$ It is already up and running in Ghana, at the time of this writing. Mr. Mamkele Mene was appointed as the pioneer Secretary-General of the CFTA in February 2020, for a four-year term. ${ }^{449}$ As the public face of the CFTA, he is expected to manage the Secretariat, engage with stakeholders,

441. KLABBERS, supra note 415, at 169.

442. AfCFTA AGT, supra note 21, art. 13(2).

443. See Decision on Hosting of the Secretariat of the African Continental Free Trade Area (AfCFTA), para. 4, Assembly of the African Union, Twelfth Extraordinary Session, Ext/Assembly/AU/Dec.2(XII) (July 7, 2019), https://au.int/sites/default/files/decisions/37553-ext assembly_au_dec_1-3_xii_e.pdf.

444. Id. para. 6 .

445. See Statement by Mahamat, supra note 1. Additionally, Ghana serves "not only as a home of thought but also as a port of safety and freedom for fellow Africans fleeing persecution, and for people of African descent seeking refuge or simply coming back home." Id.

446. Ghana ratified the Agreement on May 7, 2018, less than two months after its adoption. See AfCFTA, Ratification Status, supra note 34.

447. See generally NKRUMAH, supra note 4 (discussing the need to eliminate competition within the African Common Market).

448. Decision on AfCFTA Feb. 2020, supra note 291, para. 7.

449. Id. para. 6 . 
make other strategic collaborations, and mobilize resources for program implementation. The AfCFTA Agreement is silent on the other staff of the Secretariat and on the criteria for their appointments. It is safe to assume that selection will be based on the AU Staff Regulations and Rules, ${ }^{450}$ drawn up pursuant to Article 20 of the AU Act. The Regulations provide: "In any recruitment, appointment, transfer and promotion, preference shall be given to persons with the highest standards of efficiency, competence and integrity alongside the need to promote gender balance and equality." 451 There is also a requirement of geographical representation. ${ }^{452}$

The AU is responsible for funding the Secretariat. The Assembly will approve its budget. ${ }^{453}$ This direct appropriation makes the Secretariat an autonomous organ and guarantees its independence. Besides, the AfCFTA Agreement provides that the Secretariat shall be autonomous of the AUC. ${ }^{454}$ It should function without being tied to the apron strings and bureaucracy of the AUC. Since the Secretariat is fashioned to be international in character, its staff are expected to discharge their duties impartially. They should refrain from any action that might adversely reflect on their position as international officials. They should not seek or accept instructions from any government or any other authority external to the CFTA. They should work for the interest of the CFTA as a whole. ${ }^{455}$ The AU Staff Regulations sums up these guiding principles: "In the performance of their official duties, staff members shall neither seek nor accept instructions from the government of any Member State or from any other authority or source external to the Union." ${ }^{456}$ Of course, it is important for the CFTA members to also respect the international character of the Secretariat. A recent incident in the AU, though seemingly inconsequential, is capable of compromising that international character. At its February 2019 meeting, the AU Assembly

450. Draft African Union Staff Regulations and Rules, Reg. 6.2(a), Assembly of the Union, Fifteenth Ordinary Session, Assembly/AU/4(XV) (July 25, 2010) [hereinafter AU Staff Regulations]; see also Decision on the Staff Regulations and Rules, Assembly of the Union, Fifteenth Ordinary Session, Assembly/AU/Dec.305(XV) (July 25, 2010), https://au.int/sites/default/files/decisions/9630-assembly en_25_27_july_2010_bcp_assembly_of_the_african_union_fifteenth_ordinary_session.pdf (adopting the staff regulations and rules).

451. AU Staff Regulations, supra note 450, Reg. 6.4(b); see also id. Reg. 2.1(b); cf. U.N. Charter, supra note 345 , art. 101(3) (stating a commitment to diverse recruitment efforts by hiring from a wide geographical basis).

452. See AU Staff Regulations, supra note 450, Reg. 6.4(c); cf. Sharm El-Sheikh Protocol, supra note 32, arts. 7(4)-(5) (requiring "equitable gender representation" in electing judges of the future Court); AU Staff Regulations, supra note 450, r.28.8.

453. AfCFTA AGT, supra note 21, art. 13(1).

454. Id. art. 13(4).

455. Cf. U.N. Charter, supra note 345, art. 100(1) (providing that the staff of the UN are "responsible only to the Organization"); Revised ECOWAS Treaty, supra note 264, arts. 20(1)-(2).

456. AU Staff Regulations, supra note 450, Reg. 3.3(c). 
expressed special gratitude to Ghana for offering facilities for the CFTA Secretariat and for donating $\$ 10$ million to support its operations. ${ }^{457}$ Expressing appreciations through special resolutions appears to be the practice of the AU, but some might not be necessary. While there might be no strings attached to the gestures of the Ghanaian authority, the donation creates an impression that Ghana is paying for the "favor" of hosting the Secretariat in its territory. Its publicity by the Assembly also sends the wrong signal; otherwise, why is Ghana the only country making such a donation? Where are the other CFTA states?

The Secretariat's neutrality could be compromised if the CFTA/AU Assembly allows it to depend on handouts from a few powerful states for its functioning. Going forward, any donation received towards the CFTA or its Secretariat should go to the coffers of the AU until it is appropriated. A letter of appreciation from the CFTA Secretariat should be sufficient without the need for the AU to indulge in special resolutions.

\section{VERTICAL AND HORIZONTAL RELATIONSHIPS}

Sub-regional integration organizations are pillars of the AEC and, by extension, the CFTA. Effective continental coordination of the RECs and harmonization of their policies will be crucial to the success of the CFTA. Meanwhile, the AEC/CFTA functions on the principle of the sovereign equality of its members. ${ }^{458}$ This accords with the Westphalian conception of international law, which projects an authority-based view of society that is largely facilitated by state action. ${ }^{459} \mathrm{~A}$ state is an organized sovereign authority with exclusive membership, consciousness and ideals. ${ }^{460}$ Each state possesses a territory, population, and government, ${ }^{461}$ and enjoys the rights inherent in sovereignty, including the freedom to choose and develop its political, social, economic and cultural systems. ${ }^{462}$ Neither the AEC, the AU, nor the CFTA is a state or even a super-state. Each exercises powers that are

457. Decision on AFCFTA Feb. 2019, supra note 237, at para. 6.

458. AU Act, supra note 14, art. 4(a); U.N. Charter, supra note 345, art. 2(1).

459. See Philip Allott, EunOMiA: New ORder FOR A New World 199-202 (1990).

460. See Iain Scobbie, Some Common Heresies About International Law: Sundry Theoretical Perspectives, in INTERNATIONAL LAW, supra note 241, at 80; JARROD WIENER, GLOBALIZATION AND THE HARMONIZATION OF LAW 6 (1999) ("[S]tate authority [is defined as] the ability to exercise control over a well-defined territorial space.").

461. See Montevideo Convention on Rights and Duties of States 1933, art. 1, Dec. 26, 1933, 49 Stat. 3097, 165 L.N.T.S. 19.

462. See G.A. Res. 2625 (XXV), Declaration on Principles of International Law Concerning Friendly Relations and Co-operation Among States (Oct. 24, 1970). 
defined by its constitutive treaty or implied by necessity. ${ }^{463}$ Although states are the primary units of the international order, no common market can exist if states are unwilling to pool aspects of their sovereignties and surrender them to the Community. This Part examines the vertical and horizontal relationship between the CFTA and RECs, including the continental efforts to bring rationality or order into the policies and activities of Africa's RECs. It also examines the vertical and horizontal relationship between the CFTA and states. Among other things, I call on the continental institutions, in particular the judicial organs, to interpret Community laws and regulations in a manner that limits state sovereignties and advances the integration goals of the CFTA.

A. The Continental Free Trade Area and Regional Economic Communities

A successful CFTA will be contingent on the integration processes by the RECs. The RECs are generally seen as building blocks of economic integration. ${ }^{464}$ They will serve as basic units to construct the CFTA. Indeed, the AfCFTA Agreement seeks to build on the initiatives and developments in respective states and RECs. ${ }^{465}$ This section examines the prospective symbiotic relationship between the CFTA and RECs against the background of the latter's conflicting sub-regional trade policies. I argue that achieving policy coherence among the RECs is crucial to the attainment of continental integration objectives. I first examine the role of RECs in economic integration before looking at the options for bringing rationality to their activities.

1. Building or Stumbling Blocks?

Numerous RECs dot Africa's landscape. Those that the AU officially recognizes are the ECOWAS, the COMESA, the Economic Community of Central African States (ECCAS), the SADC, the Inter-Governmental Authority for Development (IGAD), the AMU, the Community of SaheloSaharian States (CEN-SAD), and the EAC. ${ }^{466}$ The list reflects Africa's five geographical spreads, namely North, West, Central, East, and Southern

463. For a discussion of the express and implied powers of international organizations, see KLABBERS, supra note 415, at 60.

464. AfCFTA AGT, supra note 21, pmbl., art. 5(b); cf. Niamey Declaration, supra note 191, pmbl., para. 14 (recognizing Regional Economic Communities as facilitators of regional economic integration); Declaration on Shared Values, supra note 221, pmbl. (describing RECs as "building blocks" for developing and promoting a "continental agenda for integration").

465. AfCFTA AGT, supra note 21, art. 3(c).

466. For legal text, see Revised EAC Treaty, supra note 6. 
Africa. ${ }^{467}$ It is based on a long-established policy of encouraging viable economic development projects on a regional basis. Some commentators, however, think that these 'spaghetti bowls' are stumbling blocks to the multilateral trading regimes. ${ }^{468}$ Others argue that Africa's multiple RECs reflects states' desire to pick and choose various options. They insist that multiple membership illustrates the flexibility and open-door policy that Africa's RTAs offer. ${ }^{469}$ Different RTAs offer benefits to members beyond the reduction or removal of tariff barriers and the harmonization of trade policies. $^{470}$

That RECs are essential for the promotion of Africa's socio-economic development is not in doubt. They could play crucial roles in realizing the integration agenda of the CFTA by serving as dynamic building blocks of an effective integration into the Multilateral Trading System (MTS). ${ }^{471}$ They could provide expertise for members to research trade facilitation in order to participate effectively in multilateral negotiations and enhance trade competitiveness. ${ }^{472}$ They could provide financial support to their members to develop integration programs and generally meet their AEC/CFTA timelines. ${ }^{473}$ They could help to advance Africa's shared values in the areas of democracy, good governance, human rights, gender equality, rule of law, peace building, and humanitarian concerns. ${ }^{474}$ Africa's RECs have indeed been involved in regional security issues. When the cancer of conflicts

467. Cf. Resolution on the Division of Africa into Five Regions, Council of Ministers, Twenty-Sixth Ordinary Session, CM/Res.464(XXVI) (Feb. 23, 1976), https://au.int/sites/default/files/decisions/9591council_en_23_february_1_march_1976_council_ministers_twenty_sixth_ordinary_session.pdf ("Cognisant of the fact that there are similarities in nature and extent of certain problems facing particular regions in Africa.").

468. See, e.g., Jagdish Bhagwati \& AnNe O. Krueger, The Dangerous Drift to Preferential TRADE AgreEMENTS 2-3 (1995).

469. GATHII, supra note 115 , at 67-68.

470. Id.; see also James Thuo Gathii, African Regional Trade Agreements as Flexible Legal Regimes, 35 N.C. J. INT'L L. \& COM. REG. 571, 573 (2010) (listing a myriad of benefits that African RTAs offer members, including the adoption of social economic and political objectives).

471. Declaration on the Fifth WTO Ministerial Conference, para. 7, Assembly of the African Union, Second Ordinary Session, Assembly/AU/Decl.4(II) (July 10, 2003), https://au.int/sites/default/files/decisions/9548-assembly_en_10_12_july_2003_auc_the_second_ordinar y_session_0.pdf.

472. Decision on Trade Facilitation, para. 5, Executive Council, Seventh Ordinary Session, EX.CL/Dec.204(VII) (June 28, 2005), https://au.int/sites/default/files/decisions/9629-council_en_ 28 june_2_july_2005_council_executive_council_seventh_ordinary_session.pdf.

473. Cf. Decision on Boosting Intra-African Trade, supra note 16, para. 5 (calling for RECs to support Member States in boosting intra-African trade).

474. See Declaration on Shared Values, supra note 221, para. 10 (calling upon RECs to work with the AUC and other AU organs to promote Shared Values); AU Protocol on RECs, supra note 60, pmbl. (discussing the desirability for a synergy between the AU and RECs on the promotion of these shared values). 
metastasised West Africa in the last decade of the 20th century, the ECOWAS set up a Standing Mediation Committee (SMC) to address the situations within the sub-region. The SMC midwifed the ECOWAS Ceasefire Monitoring Group (ECOMOG) which forcefully intervened to restore peace and order, notably in Liberia and Sierra Leone. ${ }^{475}$

The major problem with Africa's RECs is their overlapping membership and mandate, which dissipates manpower and resources in a continent that can least afford them. Multiple membership poses a potential conflict regarding which organization's obligations should take precedence. ${ }^{476}$ There is also the absence of clear principles of coordination among them. This leads to what has been termed the 'spaghetti bowl' - a metaphor used to describe a system in which crisscrossing strands of bilateral trade agreements create a tangled mess of restrictions and regulations, ultimately disrupting rather than promoting free trade. ${ }^{477}$ Mistrust or suspicion prevents most RECs from harmonizing their agricultural and trade policies against global threats. To this day, there is an enduring attraction by African governments to the colonizers' ways. Some RECs establish separate monetary zones to align with their former colonizers. The French assimilation policy created a bond of dependence, loyalty, and gratitude. It perpetuates neo-colonialism. The Franc Zone, a monetary and economic zone consisting predominantly of former French colonies - though Equatorial Guinea and Guinea-Bissau are also members together with France-operates on the basis of fixed parity with the CFA franc, with convertibility guaranteed by the French Treasury. ${ }^{478}$ Such conflicting interests and loyalties could make Africa's RECs become stumbling blocks on the path to the Pan-African vision of CFTA.

475. See, e.g., Peter Arthur, ECOWAS and Regional Peacekeeping Integration in West Africa: Lessons for the Future, 57 AFR. TODAY 2 (2010); Peter A. Jenkins, The Economic Community of West African States and the Regional Use of Force, 32 DENV. J. INT'L L. \& POL. 333 (2008).

476. See Udombana, A Harmony or a Cacophony?, supra note 64, at 206 ("Greater economic integration at the global level has led to the further marginalization of those countries that are unable to compete effectively.").

477. On the 'spaghetti-bowl' effect, see generally JAGDISH N. BHAGWATI, THE WORLD TRADING SYSTEM AT RISK (1991) (arguing that the concept of 'trading by rules' that underlies the General Agreement on Trade and Tariffs will be undermined by increased accusations of unfair trade practice); Joost Pauwelyn, Adding Sweeteners to Softwood Lumber: The WTO-NAFTA "Spaghetti Bowl" Is Cooking, 9 J. INT'L ECON. L. 197 (2006) (discussing trade disputes over multilateral trade rules and regional trade deals litigated in NAFTA and WTO).

478. Boris Martor et AL., Business LAW IN AFricA: OHADA AND THE HARMONIZATION PROCESS 285-86 (2d ed. 2007). 
2. In Search of Rationality

The coordination and harmonization of policies between the RECs is an imperative to the gradual attainment of the continental integration agenda. ${ }^{479}$ The AfCFTA Agreement stresses the need to resolve the challenges of multiple and overlapping memberships in order to expedite the regional integration processes. ${ }^{480}$ Multiple legal instruments define the relationship between the AEC and RECs, all seeking to establish some forms of rationality or coherence between the regional and sub-regional integration visions. These instruments include the AEC Treaty, AEC Protocol on the Relationship between the AEC and the RECs 1998, ${ }^{481}$ AU Act, AU Protocol on RECs, ${ }^{482}$ and the AfCFTA Agreement itself. Different OAU/AU organs have also adopted soft laws on the activities of RECs. In $2006,{ }^{483}$ the AU Assembly urged regional economic institutions to coordinate and harmonize their policies among themselves and with the AUC. ${ }^{484}$ It then placed a moratorium on recognition of additional RECs, besides those officially recognized. ${ }^{485}$

The AU Protocol on RECs, adopted in $2007,{ }^{486}$ is the extant legal framework for coordinating activities of RECs in Africa. This generic Protocol applies to the mechanism that the parties establish to implement measures in the economic, political, social and cultural fields to fulfil the responsibilities placed on them by the AU Act and the AEC Treaty. ${ }^{487}$ The AfCFTA Agreement falls into the list of instruments, by the ejusdem generis rule of interpretation. The Protocol invokes the AEC Treaty and stresses the need to promote closer cooperation among the RECs by coordinating and harmonizing their policies, measures, programs and activities in all fields

479. Cf. AU Act, supra note 14, art. 3(1) (prioritizing coordination and harmonization as goals for achieving the Union's overall objectives).

480. Id. art. 3(h).

481. Protocol on the Relationship Between the African Economic Community and the Regional Economic Communities, art. 3, Feb. 25, 1998, reprinted in 10 AFR. J. INT'L \& COMP. L. 157 (1998).

482. The Protocol terminates the AEC Protocol on RECs. AU Protocol on RECs, supra note 60, art. 34.

483. Decision on the Moratorium on the Recognition of Regional Economic Communities (RECs), Assembly of the African Union, Seventh Ordinary Session, Assembly/AU/Dec.112(VII) (July 1, 2006) [hereinafter Decision on RECs], https://au.int/sites/default/files/decisions/9555-assembly_au_dec_111133 vii_e.pdf.

484. Id. para. 4; cf. Accra Declaration, para. 2(a), Assembly of the African Union, Ninth Ordinary Session, Assembly/AU/Decl.2(IX) (July 3, 2007), https://archives.au.int/bitstream/handle/123456789/ 249/Assembly\%20AU\%20Decl\%202\%20\%28IX\%29\%20_E.PDF?sequence=1\&isAllowed=y (noting the reaffirmation of freedom of expression).

485. See Decision on RECs, supra note 483, para. 3 (suspending the recognition of new Regional Economic Communities until further notice).

486. AU Protocol on RECs, supra note 60.

487. Id. art. 2 . 
and sectors. ${ }^{488}$ It stresses that integrating the policies of the RECs in a timely manner will accelerate the establishment of an ACM, which is a prelude to the AEC. ${ }^{489}$ The operative part of the Protocol lays down the overall goal, which is to strengthen mutual relations among RECs, align their programs, policies and strategies with those of the AU, provide for an effective implementation of the Protocol, and the eventual absorption of RECs into the AEC. ${ }^{490}$ The AU undertakes to discharge fully its responsibility for strengthening RECs and coordinating and harmonizing their activities. ${ }^{491}$ Towards this end, the Protocol establishes a coordination mechanism to develop common positions in negotiations at the multilateral level. ${ }^{492}$ It mandates RECs to review their treaties with a view to aligning them with the AU instruments on economic integration. It establishes two organs to coordinate policies, measures, programs, and activities of RECs and ensure implementation of set objectives. These are the Committee on Coordination, and the Committee of Secretariat Officials (CSO). ${ }^{493}$ The Protocol defines their composition and functions and the implementation benchmarks for $\mathrm{RECs}^{494}$ and the AU, ${ }^{495}$ among others.

In 2017, the AU Assembly again called for a clear division of labor and effective collaboration among the AU, the RECs, the RMs, states, and other continental institutions. Such collaboration, according to the Assembly, should be based on principles of subsidiarity and comparative advantage. ${ }^{496}$ In 2018, the Assembly mandated the AUC to develop a proposal-in collaboration with other stakeholders - on an effective division of labor among these stakeholders, again based on the principle of subsidiarity. ${ }^{497}$ In 2019, the AU Assembly reiterated the necessity for rationality among RECs. It directed the AUC to prioritize promoting inter-REC cooperation with a

488. Id. pmbl.

489. Id.

490. Id. art. 5(1).

491. Id. art. 5(2).

492. Id. art. $3(\mathrm{~g})$.

493. Id. art. 6 .

494. Id. arts. 12-13.

495. See id. art. 11 (targeting Regional Economic Communities and taking into account comparable activities carried out under the AU Treaty).

496. Decision on the Outcome of the Retreat of the Assembly of the African Union on the Institutional Reform of the African Union, Annex, para. A(ii), Assembly of the Union, Twenty-Eighth Ordinary Session, Assembly/AU/Dec.635(XXVIII) (Jan. 31, 2017), https://au.int/sites/default/files/decisions/ 32520-sc19553_e_original_-_assembly_decisions_621-641_-_xxviii.pdf.

497. Decision on the Institutional Reform, para. 54, Assembly of the African Union, Eleventh Extraordinary Session, Ext/Assembly/AU/Dec.1(XI) (Nov. 17, 2018), https://au.int/sites/default/files/ decisions/36425-ext_assembly_dec._1-4xi_e.pdf. 
view to scaling up the African integration agenda. ${ }^{498}$ Welcoming the preparatory work by the AUC, RECs and RMs on the proposal of the division of labor between the various stakeholders, the Assembly directed them to prepare more detailed proposals for consideration and adoption. ${ }^{499}$

Subsidiarity is a deeply rooted principle in Western thought. It has been applied to a variety of law and governance issues, such as the environment, ${ }^{500}$ antitrust, ${ }^{501}$ and human rights. ${ }^{502}$ It is also a central constitutional principle in the EU. ${ }^{503}$ It was first defined in a Papal Encyclical of 1931, stating: "it is an injustice and at the same time a grave evil and disturbance of right order to assign to a greater and higher association what lesser and subordinate organizations can do."504 There are two recognized tests for applying the subsidiarity principle. ${ }^{505}$ The first is the negative sufficient attainment test, which states that the Community should proceed only if a member cannot achieve the set aim. The second is the positive better attainment test, which states that the Community action is preferable to member state action if it

498. Niamey Declaration, supra note 191, para. 5; see also id. para. 10 ("Request[ing] [m]ember states... [and] all other stakeholders to mobilize sufficient and sustainable resources ... including through utilizing the AU Partnerships towards the attainment of the continental integration Agenda . . .").

499. Id. para. 6.

500. See, e.g., Koen Lenaerts, The Principle of Subsidiarity and the Environment in the European Union: Keeping the Balance of Federalism, 17 FORDHAM INT'L L.J. 846 (1993); William Murray Tabb, Environmental Impact Assessment in the European Community: Shaping International Norms, 73 TUL. L. REV. 923 (1999).

501. See, e.g., Rein Wesseling, Subsidiarity in Community Antitrust Law: Setting the Right Agenda, 22 EUR. L. REV. 35 (1997).

502. See, e.g., Paolo G. Carozza, Subsidiarity as a Structural Principle of International Human Rights Law, 97 AM. J. INT’L L. 38 (2003).

503. See Consolidated Version of the Treaty on European Union, 2016 O.J. (C 202) 1, pmbl., art. 5 [hereinafter EU Treaty] (resolving to continue the process of creating an ever closer union among the peoples of Europe in accordance with the principle of subsidiarity).

504. Encyclical Letter from Pope Pius XI on Reconstruction of the Social Order para. 79 (May 15, 1931), http://www.vatican.va/content/pius-xi/en/encyclicals/documents/hf_p-xi_enc_19310515_quadra gesimo-anno.html. Many commentators trace the roots of this principle to an earlier encyclical, but it was the 1931 Encyclical that first explicitly attached 'subsidiarity' to the idea. See Patrick McKinley Brennan, Subsidiarity in the Tradition of Catholic Social Doctrine 7 (Villanova Law Sch. Pub. Law \& Legal Theory Working Paper Series, Paper No. 2013-3008, 2012), https://digitalcommons.law.villanova.edu/cgi/ viewcontent.cgi?referer=\&httpsredir=1\&params=/context/wps/article/1182/\&path_info (explaining Pope Pius XI's articulation of the principle of subsidiary function).

505. For judicial guidance on how the principle should be interpreted, see Case C-103/01, Comm'n v. Germany, 2003 E.C.R. I-5386; Case C-491/01, The Queen v. Sec'y of State for Health ex parte Brit. Am. Tobacco (Inv.) Ltd. \& Imperial Tobacco Ltd., 2002 E.C.R. I-11550; Case C-377/98, Netherlands v. Parliament, 2001 E.C.R. I-7149; Case C-84/94, U.K. v. Council, 1996 E.C.R. I-5793. See generally George A. Bermann, Proportionality and Subsidiarity, in THE LAW of THE SingLE EuROPEAN MARKET: UnPacking the PREMISES 75 (Catherine Barnard \& Joanne Scott eds., 2002) (evaluating the appropriateness of community legislative measures through the framework of subsidiarity and proportionality). 
will bring demonstrable advantages. ${ }^{506}$ For the AEC/CFTA, RECs will be authorized to only advance the integration agenda in specific areas. ${ }^{507}$ The CFTA organs will not take action in those areas not falling within their exclusive competences. They will do so only when their objectives cannot be adequately achieved by individual states or RECs. And in the event of any inconsistency between the CFTA and any REC, the former shall prevail to the extent of the inconsistency. ${ }^{508}$

In sum, the CFTA handlers must continue to work towards resolving the challenges of multiple and overlapping trade regimes. A vibrant AEC/CFTA requires the harmonization of REC policies and the strengthening of horizontal collaboration.

\section{B. The Continental Free Trade Area and Member States}

States are the primary units of the international order. The AfCFTA Agreement takes this principle for granted; for example, it affirms the right of states to flexibly regulate within their territories in order to achieve legitimate policy objectives in such areas as public health, safety, environment, public morals and the promotion and protection of cultural diversity ${ }^{509}$ But the AEC/CFTA, or the AU that oversees it, also possesses the legal capacity to regulate on trade and related matters, with implications on state sovereignty. The legal problem is that neither the AEC Treaty nor the AfCFTA Agreement contain an explicit commitment to the idea that the Community law shall be supreme. This and related problems deserve some examination because they have legal and practical implications for the effective functioning of the CFTA. It will be difficult to achieve the goals of the AEC/CFTA unless we assume the supremacy of Community law. This section examines, inter alia, the nature of relationship between the AEC/CFTA and its members and the effect of Community law on national legal systems.

\section{Regional Order and Limitation of Sovereign Rights}

Although states are the primary units of the international order, they limit their sovereign rights when ratifying a constitutive treaty. The treaty

506. MARgot Horspool \& MATthew Humphreys, European Union LAW 100-01 (5th ed. 2008).

507. See AU Protocol on RECs, supra note 60, pmbl. ("Aware of the need to define the role of the Union and that of the RECs taking into account the principle of subsidiarity and thereby allowing the RECs to advance the integration agenda in specific areas ....").

508. AfCFTA AGT, supra note 21, art. 19(1).

509. Id. pmbl.; cf. Protocol on Trade in Services, supra note 24, pmbl. ("Recognising the right of its State Parties to regulate in pursuit of national policy objectives, and to introduce new regulations, on the supply of services, within their territories, in order to meet legitimate national policy objectives ....”). 
principle that obligations can only arise from the consent of states and the principle of sovereign equality are satisfied in a formal way when states join an international organization. ${ }^{510}$ They are presumed to know that they are not merely parties to a treaty but also members of a community. They are presumed to consent to the institutional aspects of that membership. The Community thus created represents what Kissinger calls "a new unit in a new global version of the Westphalian system," albeit as a regional, not a national, power. ${ }^{511}$ The existence of this Community presupposes the existence of a constitution, although the reverse is not necessarily true. ${ }^{512}$ It will be impracticable to have an AEC/CFTA if the Community law is not supreme and directly applicable or enforceable in states. The CFTA objectives will be jeopardized if the executive force of Community law should vary from one state to another in deference to domestic laws. It must be assumed that the new system creates a new international legal order in favor of which states have limited their sovereign rights in certain areas. ${ }^{513}$

There is a plethora of legal authorities to support the claim that the AEC/AU/CFTA law will be a direct source of rights and duties for states. The Community law will bind nationals of state parties, demarcate states' competences on intra-African trade, and limit their traditional functions, such as control over borders. In the Wimbledon Case, ${ }^{514}$ the Permanent Court of International Justice (PCIJ) rejected the argument that a treaty provision could not deprive a state of the sovereign right to apply the law of neutrality to vessels passing through the Kiel Canal. In Costa v. ENEL ${ }^{515}$ the European Court of Justice (ECJ) held that the European Economic Community (EEC) Treaty created its own legal system which, upon its entry into force, became an integral part of the members' legal system and which their courts must apply. ${ }^{516}$ The Court took the same position in Amministrazione delle Finanze v. Simmenthal, ${ }^{517}$ holding that "rules of Community law must be fully and uniformly applied in all the Member States from the date of their entry into

510. CRAWFORD, supra note 241, at 452.

511. HENRY KISSINGER, WORLD ORDER 92 (2014).

512. Cf. Simon CheSterman ET AL., LAW AND Practice of THE United NATions: Documents AND COMMENTARY xxxiv ( $2 \mathrm{~d}$ ed. 2016) ("It is demonstrably possible to have a community without a formal constitution, but it is difficult to imagine a constitution without a community.").

513. Cf. Case 26/62, NV Algemene Transport- en Expeditie Onderneming van Gend \& Loos v. Nederlandse Administratie der Belastingen, 1963 E.C.R. 1, at 12 (concluding that Member States limited their sovereign rights under the European Economic Community).

514. S.S. "Wimbledon" (U.K. v. Ger.), Judgment, 1923 P.C.I.J. (ser. A) No. 1, at 25 (Aug. 17).

515. Case 6/64, Flaminio Costa v. E.N.E.L., 1964 E.C.R. 585, at 593-94.

516. Id. at 595 .

517. Case 106/77, Amministrazione delle Finanze dello Statto v. Simmenthal S.p.A., 1978 E.C.R. 629 , para. 14. 
force and for as long as they continue in force."518 Given that the African integration schema closely follows the European model, it could be submitted by analogy that the AEC/AU/CFTA law and the prospective organic decisions and regulations will have direct effects in members' municipal legal order.

The observance of the legal system of the Community is one of the operating principles in the AEC Treaty. ${ }^{519}$ Each member undertakes to take all necessary measures, in accordance with its constitutional procedures, to enact and disseminate such legislation as may be necessary for the implementation of the Treaty. ${ }^{520}$ A regulation made pursuant to the AEC Treaty has been approved by the Assembly, and it binds members, RECs, and other subordinate organs of the Community. ${ }^{521}$ Such a regulation is expected to be automatically enforceable thirty days after the date of their signature and publication in the official Community journal. ${ }^{522}$ The AfCFTA Agreement similarly empowers the CFTA Council to take decisions; and while acting within its mandate, it may make regulations, issue directives and make recommendations. ${ }^{523}$ Its decisions are binding on states, ${ }^{524}$ after their adoption by the Assembly. ${ }^{525}$ The Agreement provides that states "shall take such measures as are necessary to implement" the decisions of its organs. ${ }^{526}$ The word 'shall' is an imperative. ${ }^{527}$ Thus, the AEC Treaty provides for sanctions for any member which persistently fails to honor its general undertakings or fails to abide by the decisions or regulations of the Community. ${ }^{528}$ The AU Act makes a similar provision on decisions and policies of the AU. ${ }^{529}$

The pacta sunt servanda rule ${ }^{530}$ also bolsters the supremacy of Community law over national laws. The rule is the cornerstone of

518. Id.

519. AEC Treaty, supra note 12, art. 3(e).

520. Id. art. 5(2).

521. Id. art. 13(2).

522. Id. art. 13(3).

523. AfCFTA AGT, supra note 21, arts. 11(3)(j), (5).

524. Id. art. 11(5).

525. Id. But see Sharm El-Sheikh Protocol, supra note 32, art. 31(1)(e) (implying that AU "regulations, directives and decisions" are not binding because they are "subsidiary means for the determination of the rules of law").

526. AfCFTA AGT, supra note 21, art. 11(6) (emphasis added).

527. See Shall, Black's LAw Dictionary (9th ed. 2009) (explaining that "the mandatory sense" is what drafters typically intend and what courts typically uphold).

528. AEC Treaty, supra note 12, art. 5(3).

529. See AU Act, supra note 14, art. 23(2).

530. See VCLT, supra note 30, art. 26 ("Every treaty in force is binding upon the parties to it and must be performed by them in good faith."). 
international relations. ${ }^{531}$ Its rationale is that there will be no reason for states to enter into treaty obligations with each other if there is no reasonable belief that they will honor their commitments. ${ }^{532}$ No one builds a stately habitation unless he plans to live there. This axiomatic and self-evident rule is reinforced by a corollary rule in the Vienna Convention on the Law of Treaties (VCLT), providing that a state may not invoke its internal law as justification for failure to perform its treaty obligations. ${ }^{533}$ This is also a selfevident rule. ${ }^{534}$ There is a general presumption that states do not intend to repudiate their international obligations. ${ }^{535}$ Thus, State Parties to the AEC Treaty, the AU Act, and the AfCFTA Agreement are not expected to take unilateral measures that run afoul of the Community legal system that they freely accept on the basis of reciprocity. ${ }^{536}$ Instead, they are expected to take necessary domestic and other measures to honor their treaty obligations. ${ }^{537}$

\section{Playing by the Rules}

It is vital to the success of the CFTA that all parties should play by the rules. The obligation to perform - and to be held to account for nonperformance-restrains a state's ability to exercise its sovereignty. ${ }^{538}$ But states are entitled to invoke their sovereign rights when interpreting their obligations. $^{539}$ As already shown, the AfCFTA Agreement gives the Assembly the power to interpret its provisions. Like most treaties, the

531. See 3 Hugo Grotius, DE JuRE Belli AC Pacis [Right of War and Peace] 438 (Marci-Michaelis Bousquet ed., Lausannae 1752) (1625) (writing that the pacta sunt servanda rule lies at the center of international legal order).

532. See Malcolm N. Shaw, International Law 904 (6th ed. 2008).

533. VCLT, supra note 30, art. 27; see also Exchange of Greek and Turkish Populations, Advisory Opinion, 1925 P.C.I.J. (ser. B) No. 10, at 20 (Feb. 21); VILLIGER, supra note 195, at 372 n.15 (noting "the close relation between Articles 26 and 27" of the VCLT).

534. See Applicability of Obligation to Arbitrate Under Section 21 of the United Nations Headquarters Agreement of June 26 1947, Advisory Opinion, 1988 I.C.J. 34, ๆ 57 (Apr. 26) (citing with approval Greco-Bulgarian Communities, Advisory Opinion, 1930 P.C.I.J. (ser. B) No. 17, at 32 (July 31)).

535. See, e.g., G.A. Res. 3281 (XXIV), Charter on Economic Rights and Duties of States (Dec. 12, 1974) [hereinafter CERDS].

536. Cf. Case 6/64, Flaminio Costa v. E.N.E.L., 1964 E.C.R. 585, at 594 (noting that the Treaty allows State Parties to act unilaterally in only very narrow circumstances that are clearly listed).

537. Cf. Niamey Declaration, supra note 191 (urging state parties to align their national development and reform strategies to the CFTA).

538. CRAWFORD, supra note 241, at 450.

539. See Continental Shelf (Libya v. Malta), Judgment, 1985 I.C.J. 13, 17 (June 3); cf. AngloIranian Oil Co. (U.K. v. Iran), Judgment, 1952 I.C.J. 93, at 105 (July 22) (discussing Iran's ability to exclude disputes relating to the application of capitulatory treaties from the Court's compulsory jurisdiction); Interpretation of Peace Treaties with Bulgaria, Hungary and Romania, Advisory Opinion, 1950 I.C.J. 221, at 227 (July 18) (describing how the power in the provision at issue derives "solely from the agreement of the parties" which must be strictly construed). 
Agreement contains 'definitions' clauses to aid interpretation. ${ }^{540}$ Still, states sometimes use legal subterfuge to frustrate their treaty obligations under the guise of self-interpretation. ${ }^{541}$ In determining the meaning and terms of the AfCFTA Agreement and related treaties, the Assembly must interpret their provisions to advance the objects and purpose of the AEC/CFTA, which is economic integration through a robust intra-African trade. ${ }^{542}$ Any interpretation that defeats this purpose will not be in good faith. In like manner, the CFTA managers must not overstep their authority, otherwise it will be difficult for states to comply with the Community rules. Even a minimal surrender of sovereignty by states requires some guarantees that the Community will play by the rules.

These potential tensions and conflicts between the CFTA law and states underscore the urgent need for a continental court of justice. An independent judicial institution, with jurisdiction to interpret and apply the Community law, will ensure that states and institutional organs observe such law. The existence of such a court will also make it possible to take enforcement action against delinquent states and ensure compliance with Community law. Regrettably, the Sharm El-Sheikh Protocol adopted to establish a continental court of justice is presently in hibernation. The Protocol requires 15 ratifications for it to enter into force. ${ }^{543}$ Only seven states - Benin, Burkina Faso, Congo, Gambia, Libya, Liberia and Mali - have ratified since its adoption in $2008 .^{544}$

\section{MEASURING SUCCESS}

Collective Africa deserves commendation for adopting the AfCFTA Agreement and its supplementary protocols. These are bold steps in Africa's quest for regional economic integration and economic renewal. But negotiating and adopting treaties are the easy parts. The hard part is the degree to which the treaties produces observable and desired changes in state

540. See, e.g., AfCFTA AGT, supra note 21, art. 1; Protocol on Trade in Goods, supra note 23, art. 1; Protocol on Trade in Services, supra note 24, art. 1; AU Act, supra note 14, art. 1; AEC Protocol on Free Movement of Persons, supra note 239, art. 1; AEC Treaty, supra note 12, art. 1.

541. Some institutions attempt to solve this problem by establishing independent evaluation bodies. The World Bank and the IMF established an Inspection Panel and an Independent Evaluation Office in 2001, respectively. See, e.g., IBRAhim F.I. ShiHATA, THE World BANK INSPECTION PANEL: In PRACTICE (2d ed. 2000).

542. VCLT, supra note 30, art. 31(1).

543. See Sharm El-Sheikh Protocol, supra note 32, art. 9(1).

544. See African Union [AU], List of Countries Which Have Signed, Ratified/Acceded to the Protocol on the Statute of the African Court of Justice and Human Rights (June 18, 2020), https://au.int/sites/default/files/treaties/36396-sl-PROTOCOL\%20ON\%20THE\%20STATUTE\%20OF \%20THE\%20AFRICAN\%20COURT\%20OF\%20JUSTICE\%20AND\%20HUMAN\%20RIGHTS.pdf. 
behavior. ${ }^{545}$ The CFTA will be judged by the question whether its rules and institutions enjoy some salience within the society it governs and meet its needs, rather than by classifying it as legal. ${ }^{546}$ The life of the law is experience, not logic. In specific terms, the CFTA will be judged by the qualitative increase in intra-Africa trade and competitiveness in global trade, resulting in sustainable development and improved welfare of Africans. This final part reflects on some tough choices that Africa needs to make to move the CFTA from the realm of potential to reality.

\section{A. Towards a Robust Intra-African Trade}

The principal test of the CFTA's effectiveness will be in its ability to rejuvenate intra-African trade. That is its central objective. ${ }^{547}$ All other objectives are ancillary or tangential. Low trade is Africa's Achilles' heel. Agenda 2063 put the level of intra-African trade at 12 percent ${ }^{548}$ Most of the sub-regions export less than 5 percent of world trade. ${ }^{549}$ The major reason for the low trade is the high tariff that businesses face when exporting within Africa, not to mention non-tariff barriers examined in this paper. The intraAfrican tariff on goods is at an average of 6.1 percent. ${ }^{550}$ Removing trade barriers is critical to Africa's economic growth. The UNECA estimates that the CFTA could boost intra-African trade by 52.3 percent by eliminating import duties, which could double if non-tariff barriers are also reduced. ${ }^{551}$ AfCFTA, the AU, RECs, states, the private sector, and international partners deepen cooperation on multiple levels. ${ }^{52}$ These include addressing factor mobility, building infrastructure, adding value to primary products, and capacitating small and medium enterprises (SMEs), among the many issues demanding attention. I briefly address these issues.

545. Kal Raustiala, Compliance \& Effectiveness in International Regulatory Cooperation, 32 CASE W. RES. J. INT'L L. 387, 394 (2000).

546. Cf. CRAWFORD, supra note 241, at 11 (discussing the shift towards understanding law through sociological theories and a more pragmatic natural law approach).

547. See AfCFTA AGT, supra note 21, art. 3(a).

548. Agenda 2063, supra note 52, para. 26.

549. See African Statistical Yearbook 2018, 2018 Y.B. Afr. Stat. 86 (showing intra-African trade by economic groupings in 2015).

550. UNECA, $Q \& A$, supra note 36

551. Id.

552. See Decision on the Launch of the Operational Phase of the African Continental Free Trade Area (AfCFTA), para. 15, Assembly of the African Union, Twelfth Extraordinary Session, Ext/Assembly/AU/Dec.1(XII) (July 7, 2019) [hereinafter Decision on Operational Phase], https://au.int/sites/default/files/decisions/37553-ext_assembly_au_dec_1-3_xii_e.pdf. 


\section{Addressing Factor Mobility}

The CFTA states should urgently address all institutional and regulatory capacity gaps towards implanting the common policy on factor mobility, as contained in the Protocol on the Free Movement of Persons. The AU itself acknowledges that accelerating widespread labor migration within Africa will contribute to development and poverty eradication. ${ }^{53}$ The problem is that reality does not match rhetoric, a familiar one. Only 32 of the 55 AU members have signed the Protocol on the Free Movement of Persons. ${ }^{554}$ Of the 32, only four have ratified: Mali, Niger, Rwanda, and Sao Tome \& Principe. ${ }^{555}$ This represents 7 percent of the total AU members, 8 percent of the 50 State Parties to the AEC Treaty, and 14 percent of the 28 State Parties to the AfCFTA Agreement and its protocols. Such a dispiriting attitude evinces a lack of political commitment towards intra-African trade liberalization. It exposes the huge gaps that still remain between rhetoric and reality. The speedy ratification and implementation of the Protocol will bring the CFTA closer to Africans, who are major stakeholders in the integration project. There is really no sense in hastily ratifying the AfCFTA Agreement to give birth to the CFTA and failing to ratify complementary treaties.

The AU and its members should work to dismantle the many colonial structures that continue to imprison and enslave Africans. The arbitrary internal divisions imposed by history have left Africans more isolated, both from each other and the world as a whole. ${ }^{556}$ These colonial legacies are inimical to trade. They stymie Africa's quest for economic integration and sustainable development. They also make the concept of an 'African Union' meaningless. Pre-colonial boundaries, where they existed, were not conceived as immutable walls of division and separation. Such borders served as transactional spaces for mediating various social, economic,

553. Declaration on Employment, Poverty Eradication, Inclusive Development in Africa, pmbl., Assembly of the Union, Twenty-Fourth Ordinary Session, Assembly/AU/Decl.6(XXIV) (Jan. 30, 2015) [hereinafter Declaration on Employment], https://au.int/sites/default/files/decisions/9665-assembly_au_ dec_546_-_568_xxiv_e.pdf; $c f$. Communique, para. 3, Peace and Security Council, Six Hundred and Sixty First Meeting, PSC/PR/COMM.1(DCLXI) (Feb. 23, 2017), https://www.peaceau.org/uploads/661-psccomm-23-02-2017free-movement-of-people-final.pdf (stressing the benefits of factor mobility, which far outweigh the real and potential security and economic challenges that may be perceived or generated).

554. African Union [AU], List of Countries Which Have Signed, Ratified/Acceded to the Protocol to the Treaty Establishing the African Economic Community Relating to Free Movement of Persons, Right of Residence and Right of Establishment (July 16, 2019), https://au.int/sites/default/files/treaties/36403sl-PROTOCOL\%20TO\%20THE\%20TREATY\%20ESTABLISHING\%20THE\%20AFRICAN\%20EC ONOMIC\%20COMMUNITY\%20RELAT. ...pdf.

555. See id.

556. Kagame Report, supra note 228, at 3. 
political, and cultural flows. ${ }^{557}$ The establishment of a Single Air Transport Market (SAATM) within the framework of Agenda 2063 is a step in the right direction. ${ }^{558}$ The initiative seeks to fast-track intra-African mobility in the field of air transport. ${ }^{559}$ As the market goes into operation, intra-African market will operate without the need for bilateral air service agreements between states. ${ }^{560}$ Under the arrangement, eligible airlines of AU members and nationals operating under SAATM are entitled to file and fly on the basis of their own economic considerations, without any hindrance. The only consideration will be the safety and security of states' aviation authorities, RECs, and the Executing Agency. ${ }^{561}$ Twenty-three AU members declared their commitment to the immediate implementation of the SAATM decision, ${ }^{562}$ though some-like Nigeria-have no national carriers. States that have signed up to arrangement will be required to abolish any provisions in their Bilateral Air Services Agreement (BASAs) for intra-African air services that are contrary to the SAATM. If properly funded, the SAATM initiative will enhance connectivity across Africa and lead to sustainable development of the aviation and tourism industry, with immense potentials for job creation. ${ }^{563}$ There will be need to complement this initiative with a masterplan for intra-African highways to facilitate the movement of persons and goods.

2. Effective Domestic Institutions Underpinned by the Rule of Law

Domestic political support and credible institutions are essential to facilitate free market objectives. Good institutions-rule of law, clear property rights, stable means of exchange, efficient tax collection, the provision of public goods, checks on official corruption-do not necessarily guarantee economic prosperity, but they are the fundamental prerequisites

557. AFrICAN UNION, AUDIT OF THE AFRICAN UNION para. 3 (2007), https://www.securitycouncilreport.org/atf/cf/\%7B65BFCF9B-6D27-4E9C-8CD3-CF6E4FF96FF9\%7D/ RO\%20Audit\%20of\%20the\%20AU.docx.

558. See Decision on the Establishment of a Single African Air Transport Market, para. 4, Assembly of the Union, Thirtieth Ordinary Session, Assembly/AU/Dec.665(XXX) (Jan. 28, 2018), https://au.int/sites/default/files/decisions/33908-assembly_decisions_665_-_689_e.pdf.

559. Id. para. 8(i).

560. Id.

561. Id. para. 8(ii).

562. See id. para. 5. The AU Assembly has mandated its Commission, the Regional Economic Communities (RECs) and the Champions, in collaboration with other air transport stakeholders, to take effective steps to engage states which have not yet signed on to the Single Air Transport Market (SAATM). Id. para. 8(iv).

563. Id. para. 4. 
for sustained economic growth. ${ }^{564}$ Without them, it is difficult to maintain long-term savings and investments. ${ }^{565} \mathrm{Law}$ is said to be the enterprise of subjecting human conduct to the guidance of rules. ${ }^{566}$ It is a product of sustained purpose aimed at facilitating the conduct of public and private life. It is also predictive of state behavior; and the ability to predict presupposes order of some sort. ${ }^{567}$ As Herdegen explains:

The normative framework for an effective market economy requires essential elements, such as the guarantee of private property, the freedom of contract, and an effective legal protection of fundamental and other subjective rights. In addition, institutional mechanisms which secure economic stability and which restrain self-serving influences of particular societal groups are also vital for a functioning market economy. ${ }^{568}$

Africa must be competitive even within the continent in order to survive the onslaughts of neo-liberalism. Competitiveness depends largely on national legal orders. Africa must construct a system that recognizes individual property rights and integrate those rights into a floundering economy. Every developed nation went through the transformation from predominantly informal, extra-legal, ownership to a formal, unified legal property system, which converts assets into capital and allows people to leverage property into wealth. ${ }^{569}$ Africa is rich in assets, but poor in capital. ${ }^{570}$ Assets cannot become capital unless governments guarantee good governance anchored to the rule of law. The law of contracts must be clear on the ownership of assets and legal titles. That way, assets can be sold, bought, mortgaged, or converted into other assets. ${ }^{571}$

Allied to the need for clear rules on ownership of assets is the necessity to develop legal and policy frameworks to reduce the cost of doing business in Africa. States must create an environment conducive to private sector growth. A robust infrastructure will also catalyze manufacturing, skills development, technology, research and development, investments, tourism,

564. Adam S. Posen, The Post-American World Economy: Globalization in the Trump Era, FOREIGN AFF. (Mar./Apr. 2018), https://www.foreignaffairs.com/articles/united-states/2018-02-13/postamerican-world-economy.

565. Id.

566. LON L. Fuller, THE Morality OF LAW 106 (1964).

567. See id.

568. HERDEGEN, supra note 81, at 165.

569. See id.

570. Paul Collier, The Bottom Billion: Why the Poorest Countries Are Failing and What CAN Be Done ABOUt It 84, 87 (2007).

571. See C. K. Prahalad, The Fortune at the Bottom of the Pyramid: Eradicating POVERTY THROUGH PROFITS 78-79 (2004). 
and ultimately enhanced intra-African trade. ${ }^{572}$ The AU indicates that by 2063, Africa will have the necessary infrastructure-including high-speed railway networks, roads, shipping lines, sea and air transport-to support Africa's accelerated integration and growth, technological transformation, trade, and development. ${ }^{573}$ This sounds noble, except that a continent that is lagging behind in all indices of development cannot afford such long-term dreams. Africa needs to develop trade-related infrastructure and productive capacity-building programs immediately, not in the far future. The art of life consists in tackling each immediate evil as best as we can. AfCFTA members should identify focal points at national and regional levels and dedicate technical and financial resources to drive the CFTA.

\section{Adding Value to Africa's Primary Products}

Africa must diversify its production capabilities in order to add value to its primary commodities and expand regional value chains. Africa's market is broad enough to absorb the products of planned industrial and agricultural growth, but its prosperity lies in developing local capacities for processing. Technological innovation and technology diffusion hold enormous potential for accelerated agricultural productivity. What most states are familiar with is to export raw materials and import manufactured goods in addition to services. Foreign multinationals also control the extractive industries that many states depend on for their foreign exchange earnings. Yet four decades earlier, these states pledged "to eliminate all forms of foreign economic exploitation particularly that practiced by international monopolies so as to enable their peoples to fully benefit from the advantages derived from their national resources." 574

The AU commits to ending hunger by 2025, by strengthening development policies as an effective investment in human capital. ${ }^{575}$ It also

572. See Agenda 2063, supra note 52, para. 25; cf. AfCFTA AGT, supra note 21, pmbl. (acknowledging that an adequate infrastructure will create an expanded and secure market for goods and services of its State Parties).

573. Agenda 2063, supra note 52, para. 25.

574. African Charter on Human and Peoples' Rights, art. 21(5), June 27, 1981, 21 I.L.M. 58 [hereinafter African Charter]; see CERDS, supra note 535, art. 2(2)(a); cf. G.A. Res. 626 (VII), Right to Exploit Freely Natural Wealth and Resources, pmbl. (Dec. 21, 1952) (discussing the need to encourage under-developed nations to use their own natural resources); G.A. Res. 2158 (XXI), Permanent Sovereignty Over Natural Resources (Nov. 25, 1966) (noting that developing countries are in better positions to exploit and market their own natural resources).

575. See Decision on the Report of the High Level Meeting on Renewed Partnership for a Unified Approach to End Hunger in Africa by 2025 Under the Framework of the Comprehensive Africa Agricultural Development Programme, Executive Council, Twenty-Fourth Ordinary Session, EX.CL/Dec.797(XXIV) (Jan. 28, 2014), https://amcomet.wmo.int/sites/default/files/field/doc/events/ ex_cl_dec_783-812_xxiv_e.pdf. 
commits to reducing stunting in children to 10 percent and underweight to 5 percent by that target date, and to focus on "the first 1000 Days as the only window of opportunity during which permanent and irreversible physical and mental damage would be avoided." 576 It has promised to pursue agriculture-led growth as a main strategy to achieve targets on food and nutrition security and shared prosperity, and to halving poverty by 2025 , through inclusive agricultural growth and transformation. ${ }^{577}$ The Assembly has called on the AU Commission (AUC) and the NEPAD Planning and Coordinating Agency (NPCA) to conduct agricultural review process on a biennial basis, beginning from 2017, and to report on progress. ${ }^{578}$ The AU further promises that by 2025, Africa will banish the hand-hoe method of farming and expand the introduction of modern agricultural systems, technology, practices and training. ${ }^{579}$ Beyond these commitments, Africa needs coherent policies and institutional governance arrangements at national and regional levels-including inter-sectoral coordination-in order to unlock the huge potentials in agriculture, generate wealth, and create social benefits. To achieve food security, states must embark on aggressive agrarian reforms - including the conditions of land ownership — as well as tax, credit, and investment policy reforms. ${ }^{580}$ To create value chains, states must use better seeds and methods of cultivation and irrigation. They must also create agro-allied industries. Perpetually exporting primary products to, and importing finished goods from, the West is the textbook definition of underdevelopment. As Africans proverbially ask, when you pledge your piece of land in order to buy a bunch of brooms, what benefit do you derive from killing flies with it?

The AU should assist those of its members facing challenges in collecting and compiling quality data to report progress on all goals and targets set in the Malabo Declaration. It should work with its members and international partners, including the Food and Agricultural Organization (FAO), to facilitate agro-research and processing. Some commentators suggest that future trade preferences by advanced countries to African states should prioritize the development of productive capacities and value addition of indigenous products. This could be done through targeted investments that help states to produce goods that have higher value. It could help Ghana, for example, to transition from exporting cocoa beans to chocolate and allied

576. See Decision on ALN, supra note 258, para. 4.

577. Malabo Declaration, supra note 255, paras. 1, 3.

578. Id. para. $9(\mathrm{~d})$.

579. Agenda 2063, supra note 52, para. 72(e).

580. See Udombana, Keeping the Promise, supra note 257, at 172-73. 
products. ${ }^{581}$ I agree. Indeed, some countries - notably Burundi, Ethiopia, Kenya, Lesotho, Madagascar, Mali, Mauritius, Nigeria, Rwanda, Tanzania, and Zambia - have already developed strategies for targeted policy options to address constraints on capacity and production inputs for selected sectors in the context of AGOA. ${ }^{582}$ The setback caused by Covid-19 to trade and the multilateral system could be a blessing in disguise. It could make state parties speed up the CFTA processes and rethink their value chains and reduce their reliance on traditional supply routes. ${ }^{583}$ "Sweet are the uses of adversity." 584

4. Capacitating Africa's Small and Medium Enterprises

Collective Africa should mainstream small and medium enterprises (SMEs) into the CFTA so they can meaningfully contribute towards realizing Africa's integration objectives. SMEs are critical to Africa's economic growth and job creation. ${ }^{585}$ They are potential seedbeds for technological acquisition and innovation, which could enable them to compete with foreign conglomerates operating in Africa. But Africa's SMEs exist largely in the realm of potential. They experience many constraints such as difficulties in access to credit and capital markets and low levels of technical and managerial skills. There are also constrains of inadequate information and low productivity and quality. They face constraints of insufficient access to markets, to new technologies, and lack of transport and communications infrastructure. ${ }^{586}$ They face constraints of inappropriate, inadequate, or overly burdensome registration, licensing, reporting, and other administrative requirements, which sometimes constitute disincentives to the hiring of personnel. ${ }^{587}$ Insufficient support for research and development as well as difficulties in access to public and private procurement opportunities further constrain many SMEs. ${ }^{588}$

In 2019, the AU Assembly supported a capital increase for the African Development Bank (ADB) to enable it fulfill its role in furthering the African integration agenda. ${ }^{589}$ The AU could work with its members to identify

581. Joy Kategekwa, Rethinking the AGOA Model: How to Create a Pro-Structural Transformation of the U.S.-Africa Trade Partnership, 111 AM. J. INT'L L. UnBOUND 372, 372 (2017).

582. Davis, supra note 94, at 379-80.

583. See Statement by Mahamat, supra note 1 (arguing that the COVID-19 pandemic presents an opportunity for African Union countries to reshape their trade policies).

584. William ShakesPeare, AS you LiKe IT, act 2, sc. 1.

585. Declaration on Employment, supra note 553, pmbl.

586. See Int'1 Labour Org. [ILO], R189—Job Creation in Small and Medium-Sized Enterprises Recommendation, paras. 6(2)(a)-(g) (June 17, 1998), https://www.ilo.org/dyn/normlex/en/f?p= NORMLEXPUB:12100:0::NO::P12100_ILO_CODE:R189.

587. Id. para. $6(2)(\mathrm{h})$.

588. Id. paras. 6(2)(i)-(j).

589. Niamey Declaration, supra note 191, para. 13. 
SMEs with continental investment potentials and assist them to access loans from the ADB, with government guarantees. Such loans will enable them to improve local contents and increase their chances of effective participation in intra-African and even global trade. Giving preferences to SMEs in the award of government contracts should be seen as legitimate, "even if in doing so, multinational firms are in effect discriminated against." ${ }^{, 590}$ I reiterate my call for the adoption of a charter on SMEs. Such a charter should commit governments to provide incentives and equal opportunities for all SMEs to access credit facilities and foreign exchange. ${ }^{591}$ It should also commit governments to simplify and decentralize business registration in order to eliminate the link between high administrative burdens and corruption. And it should contain obligations for periodic reports by states on the implementation of policies contained in it. ${ }^{592}$

\section{B. Competitiveness in Global Trade}

The AfCFTA Agreement is primarily designed to facilitate intraAfrican trade, but it has a secondary objective - to enhance competitiveness of Africa's economies in the global market. ${ }^{593}$ The Protocol on Trade in Services also desires to "harness the potential and capacities of African services suppliers ... to engage in regional and global value chains." 594 These provisions have a context. Collective Africa has consistently fallen short in global trade. Its share hovers around 2 percent. ${ }^{595}$ The challenges that prompted many states to join the WTO, such as limited trade opportunities, remained several years after their accessions to the WTO agreements. ${ }^{596}$ Following the conclusion of the Uruguay Round of trade negotiations, several African states opened up their economies to global markets in the name of 'free trade'. They lowered custom tariffs and made labor markets more flexible, often at the expense of local industries. In consequence, Africa has become a dumping ground for cheap, sometimes toxic, foreign goods, even as advanced countries refuse to commit to reciprocity on trade-related issues. The West and China continue to give generous agricultural subsidies to their farmers and to adopt other protectionist measures. ${ }^{597}$ They get away with un-free trade and craftily win

590. STIGLITZ \& CHARLTON, supra note 123, at 273 (emphasis in original).

591. See Udombana, Social Rights Are Human Rights, supra note 140, at 225-26.

592. See id. at 226.

593. AfCFTA AGT, supra note 21, art. 3(f).

594. Protocol on Trade in Services, supra note 24, pmbl. (emphasis added).

595. See Agenda 2063, supra note 52, para. 26.

596. See Udombana, A Question of Justice, supra note 323, at 1166.

597. See id. at 1175. 
exemptions for various forms of subsidies while prohibiting those that developing countries apply. ${ }^{598}$ Subsidies and other protective measures depress Africa's primary products.

Africa seldom balances its trading accounts, due to trade deficits. The continent realized US\$ 426,432 million in 2017 in global merchandise exports in which China alone accounted for US\$2,263,346 million, while the U.S. accounted for US\$ 1,546,273 million. ${ }^{599}$ Africa's imports trade flow for the same period was US\$533,600 million, representing a deficit of 28 percent of total exports. ${ }^{600}$ To balance these deficits, states usually resort to loans from the IFIs. The IMF Articles of Agreement, ${ }^{601}$ for example, empowers the Fund to provide financial assistance to help members address their balance of payment problems. ${ }^{602}$ Africa has been in a perpetual debt crisis. It borrows not only to meet its international trade obligations but also to service interest on old debts, which are largely determined by the industrial countries that control the IFIs. The world's poorest countries have about $\$ 140$ billion in general government debt-servicing obligations to settle by the end of 2020, including $\$ 10$ billion in foreign currency. ${ }^{603}$ The median debt level of Sub-Saharan Africa - as defined by the IMF-is above 50 percent of its GDP ${ }^{604}$ Ghana spends 5.7 percent of her GDP on debt servicing, but 1.1 percent on health-care.$^{605}$ The ratio for Kenya is 3.9 to 2.1 percent, and 1.6 to 0.5 percent for Nigeria. ${ }^{606}$ Africa's economic geometry is a vicious cycle of low trade plus loans plus debts, which equals poverty.

The asymmetrical trade and monetary relationships between the developed and developing countries create dependency. ${ }^{607}$ They erode, in particular, Africa's ability to pursue policies that would serve its key

598. Cf. STIGLiTZ, supra note 135, at 244 (describing how industrial nations advocate for opening markets, yet continue to provide billions in subsidies to their own producers).

599. Data, WTO, https://data.wto.org/ (last visited Jan. 30, 2021).

600. Id.

601. Articles of Agreement of the International Monetary Fund, adopted Dec. 27, 1945, 2 U.N.T.S. 39 (amended effective Jan. 26, 2016).

602. See id. art. 5(3).

603. Alonso Soto, African Union May Ask Wealthy Nations for Commercial-Debt Relief, BlOOMBERG (Apr. 23, 2020, 12:14 PM), https://www.bloomberg.com/news/articles/2020-04-23/africanunion-may-ask-wealthy-nations-for-commercial-debt-relief.

604. Africa in the Red: Increasing Debt in Many African Countries is a Cause for Worry, ECONOMIST (Mar. 8, 2018), https://www.economist.com/middle-east-and-africa/2018/03/08/increasingdebt-in-many-african-countries-is-a-cause-for-worry.

605. Soto, supra note 603.

606. Id.

607. $C f$. James Crawford, Foreword to ANTONy ANGHIE, IMPERIALISM, SOvereignty AND THE MAKING OF INTERNATIONAL LAW xii (2005) (describing the creation of indebtedness and dependence as a result of nations obtaining independence from their colonizers). 
developmental objectives. ${ }^{608}$ This double standard partly explains why many developing countries have been reluctant to further open up their economies in the name of free trade. The WTO launched the Doha 'Development' Rounds (DDR) in 2001 to place development at center of the multilateral trading system. The development-related issues that mattered most to developing countries were agriculture, intellectual property, public health, and preferential trade.$^{609}$ The $\mathrm{AU}$, acting on behalf of its members, urged the industrial countries to show greater flexibility in their negotiating positions. It emphasized that the success of the DDR will depend on its development outcomes. ${ }^{610}$ The industrial countries failed to make meaningful progress on these issues; instead, the DDR was dominated by topics and proposals that were of little relevance to developing countries. It eventually collapsed after many missed deadlines, thus foreclosing international economic law's promise of justice, at least in the short term. ${ }^{611}$ Its collapse signals that any future multilateral trade arrangement that ignores the special concerns of developing countries will fail. To ignore such issues is to perpetuate dependency.

In July 2019, the AU Assembly directed the African Ministers of Trade (AMOT) to work towards ensuring that an African secure the position of the WTO's Director General when it becomes vacant after August 31, 2020. ${ }^{612}$ The AU hopes that such an African head will help to strengthen the multilateral trading system, ${ }^{613}$ possibly in Africa's favor. This is a legitimate aspiration. African states are entitled to seek greater participation in governance institutions in which they belong, but their economic challenges

608. See Decision on WTO Negotiations, para. 4, Assembly of the African Union, Seventh Ordinary Session, Assembly/AU/Dec.119 (July 1, 2006), https://au.int/sites/default/files/decisions/9555assembly_au_dec_111-133_vii_e.pdf (emphasizing that failure to meet Africa's trade negotiation needs will undermine developmental objectives).

609. See Michael Friis Jensen \& Peter Gibbon, Africa and the WTO Doha Round: An Overview, 25 DEV. POL'Y REV. 5 (2007) (listing major impediments to African trade).

610. Declaration on the Outcome of the 6th WTO Ministerial Conference Held in Hong Kong, China, 13-18 December, 2005, paras. 4-5, Sixth Ordinary Session, Assembly/AU/Decl.1(VI) (Jan. 23, 2006), https://archives.au.int/bitstream/handle/123456789/1661/Declaration_Outcome_WTO_Minister ial_Conference_E.pdf? sequence=1\&isAllowed=y.

611. See The Doha Round Finally Dies a Merciful Death, FIN. TIMES (Dec. 21, 2015), https://www.ft.com/content/9cb1ab9e-a7e2-11e5-955c-1e1d6de94879 (explaining how tensions between developing countries, developing countries' rapid economic development, and the American farm lobby's influence sunk the Doha Round). See generally Christian Bjornskov \& Kim Martin Lind, Where Do Developing Countries Go After Doha? An Analysis of WTO Positions and Potential Alliances, 36 J. WORLD TRADE 543 (2002) (tracking the disagreements between WTO members); SundHYA PAHUJA, DECOLONISING INTERNATIONAL LAW (2011) (arguing that international law has legitimated interventionism in the Third World).

612. Decision on Operational Phase, supra note 552, para. 16.

613. Id. 
extend beyond WTO headship. Having an African as Director-General is good, but it will not guarantee Africa's greater participation in the global economic and financial system. It also will not rectify the supply-side constraints caused by domestic factors, as already examined. Africa's competitiveness in the global market will be best guaranteed through value addition to its primary products and by addressing other internal challenges like poor infrastructure.

\section{Sustainable Prosperity and Peace}

The success of the CFTA will be measured by the substantive freedoms that Africans enjoy. ${ }^{614} \mathrm{~A}$ successful economic integration will undoubtedly bolster economic growth in Africa, but whether it will engender individual prosperity is a different question. Economic growth is not synonymous with individual prosperity or happiness any more than the resources a person commands is indicative of his quality of life. Development means growth plus change, and change implies objectives beyond simple GDP growth. SSA has experienced high GDP growth in the past that did not translate into proportionate job creation and poverty reduction. The AU celebrated the sustained levels of growth that Africa experienced over the last decade in $2015,{ }^{615}$ but it admitted in the same year that a significant proportion of the population remains vulnerable to challenges of economic marginalization, hunger and malnutrition. ${ }^{616}$ Poverty is exploding in Africa, caused, in part, by hunger and malnutrition; ${ }^{617}$ likewise insecurity, a by-product of poverty, is exploding. At the time of writing, it is estimated that 23 million more Africans will be pushed to extreme poverty in 2020 due to the Covid-19 pandemic. ${ }^{618}$ The poverty that afflicts Africa is not an equal opportunity offender. Inequality abounds due to what Collier calls "the survival of the fattest" and the law of the jungle of electoral competition in the presence of

614. See SEN, supra note 313, at 18. See generally THE QuALITY OF LiFE (Martha Nussbaum \& Amartya Sen eds., 1993) (addressing issues of defining and measuring the quality of life); KARL MARX, ECONOMIC AND PHILOSOPHIC MANUSCRIPTS OF 1844 (Martin Milligan trans., Progress Publishers 1959) (1932) (arguing for a reorientation of economic preoccupations).

615. Agenda 2063, supra note 52, para. 66(b).

616. See Declaration on Employment, supra note 553, pmbl. (noting with concern the persistent employment and health issues in Africa); Malabo Declaration, supra note 255, pmbl. (noting how the failings of the African agricultural sector have contributed to the continent's employment and health issues).

617. See Malabo Declaration, supra note 255, pmbl. (reflecting that hunger and malnutrition lead to poverty by causing low productivity and educational attainment).

618. Gilbert F. Hounbo, What's Needed to Protect Food Security in Africa During COVID-19, WORLD ECON. F. (May 29, 2020), https://www.weforum.org/agenda/2020/05/what-s-needed-to-protectfood-security-during-covid-19/. 
abundant resources. ${ }^{619}$ Poverty and inequality persist because of the failure to address several governance issues, including the structural problems that could reduce dependence on social safety nets.

Africa needs a sound economic theory that drives development in order to free its vast populations who are trapped in extreme poverty. ${ }^{620}$ More importantly, it needs a consequentialist ethic to respond to human needs, perhaps something akin to Mill's utilitarianism. ${ }^{621}$ Mill interprets moral value in terms of the usefulness of an action in promoting the greatest good of the greatest number. ${ }^{622}$ His philosophy contrasts that of Nietzsche, the German philosopher who renounces compassion as a sign of life-denying moral ill-health that threatens to prevent humanity from reaching its full potential. ${ }^{623}$ Mill's utilitarianism goes back to Aristotle's theory of the morally happy life. ${ }^{624}$ At the beginning of the Nicomachean Ethics, Aristotle notes that "wealth is obviously not the good that we are seeking, because it serves only as a means; i.e., for getting something else." ${ }^{~} 25$ For him, human happiness is the supreme good, "the end to which our actions are directed." 626 Happiness "makes life desirable," and is "something perfect and selfsufficient." 627 The AU similarly aims to "promote co-operation in all fields of human activity to raise the living standards of African peoples."628 The $\mathrm{AU}$ and its members should disenchant such provisions from the realm of the ideal to the actual. As a point of departure in the drive towards meeting human security, Africa should adopt a common policy on employment and social security. A continent that is moving towards economic integration must have common positions on issues that are vital to sustainable

619. COLLIER, supra note 570, at 42 .

620. Cf. JefFrey D. SAChS, COMmon Wealth: ECONOMiCs FOr a Crowded Planet (2008) (presenting a new paradigm that offers practical solutions to problems stemming from overpopulation).

621. See generally John StuART Mill, Utilitarianism (George Sher ed., Hackett Publishing Co. $2 \mathrm{~d}$ ed. 2001) (1863) (defining utilitarianism and arguing for its acceptance as a moral standard).

622. See id. at 7 ("[A]ctions are right in proportion as they tend to promote happiness, wrong as they tend to produce the reverse of happiness.").

623. See Friedrich Nietzsche, On the Genealogy of Morality passim (Keith Ansell-Pearson ed., Carol Diethe trans., Cambridge Univ. Press 2006) (1887).

624. ARISTOTLE, supra note 343.

625. Id. at 9 .

626. Id. at 15 .

627. Id. at $14-15$

628. AU Act, supra note 14, art. 3(k) (emphasis added); cf. AEC Treaty, supra note 12, pmbl. ("Conscious of [the] duty to develop and utilize the human and natural resources of the Continent for the general well-being of our peoples in all fields of human endeavour.”) (emphasis added). 
development and prosperity. Certain matters cannot be left to the discretion of individual Member States. ${ }^{629}$

Peace is both a constitutive and an instrumental freedom. It is cherished in and by itself, but it is also a means to sustainable development. ${ }^{630}$ The AEC Treaty stresses the necessity to promote peace and stability as prerequisites for the implementation of Africa's development and integration agenda. ${ }^{631}$ The reverse is also true. There can be no peace and stability without development and prosperity. Some commentators insist that open, free, and non-discriminatory trade promotes interstate relations that are conducive to peace. Where goods do not cross borders, according to Frederic Bastiat, soldiers will. ${ }^{632}$ The EU experiment may not have ushered in a "perpetual peace" in Europe, but it promoted political stability by bolstering peace between the continent's major powers after centuries of conflicts. ${ }^{633}$ The interdependence and economic prosperity that the EU ushers contribute to the relative peace that prevailed after two world wars in a single century. ${ }^{634}$ The EU has achieved this goal largely because its founders pragmatically appealed to citizens' economic empowerment rather than pander to mere nationalistic or even racial ideals. In essence, a successful CFTA will engender economic growth and prosperity and advance peace and stability in a continent that is plagued by political instability and conflict.

\section{CONCLUSION: A STEP CLOSER}

The adoption of the AfCFTA Agreement is a step closer in the on-again, off-again, rhythm towards regional economic integration. The success of the CFTA will depend on continuous political, financial, and technical support,

629. Cf. Udombana, Social Rights Are Human Rights, supra note 140, at 223 (advocating for the AU to be a pivot and catalyst in promiting social rights in Africa).

630. See generally Post-Conflict Security, Peace and Development: Perspectives from AFriCA, LATIN AMERICA, EUROPE AND NEW ZEALAND (Christine Atieno \& Colin Robinson eds., 2019) (examining linkages between regional stability, development, and peace in post-conflict societies); THE Security-Development Nexus: Peace, Conflict and Development (Ramses Amer et al. eds., 2012) (providing a comprehensive account of conflict, security, and peace through eight geographical case studies, two of which are based in the DRC and South Africa).

631. AEC Treaty, supra note 12, pmbl., art. 3(f).

632. See HERDEGEN, supra note 81, at 22 (attributing the quote to nineteenth-century philosopher Frederic Bastiat).

633. See Mark Baimbridge et AL., Current Economic Issues in EU InTEgration 1 (2004) (noting that the process of European integration has helped avert conflict and consolidate peace after the Second World War).

634. See generally Volker R. Berghahn, Europe in the Era of Two World Wars: From MiLITARISM AND GENOCIDE TO CIVIL SOCIETY, 1900-1950 (2006) (detailing the emergence of Europe's liberal capitalist model of society). 
including timely provision of information by the members. ${ }^{635}$ Decades of failed legal and policy measures at the national and regional levels make cynicism a natural ally. If - an uppercase IF-faithfully implemented, the CFTA could orchestrate a major geopolitical shift and reposition Africa to play its rightful role in the global economy and in international negotiations, which is one of the AU objectives. ${ }^{636}$ Collective Africa must give the CFTA the priority it deserves. There will be bumps on the road, but each step forward will do a lot of good for millions of Africans. No doubt, the docket of the AU is filled with issues demanding urgent attention, but the AU should prioritize the CFTA and work with its members to achieve set targets. Even if the AU has enough assets to fuel its long-term goals, it does not have the luxury of time to kitchen-sink all of Africa's problems. States that have not yet ratified the relevant regional treaties should do so and get on board the integration ship. If they fail to do so before the new official trading in January 2021 begins, more than half of Africa might be out of the trading area. This could have negative economic consequences for the individual countries in particular and for Africa in general. Those countries will remain exposed to the cold winds of globalization, not to mention marginalization in global trade. It will also mean that Africa's avowed common position on international trade and other issues is a farce.

Collective Africa must ensure, through deliberate and targeted public support, that all segments of the population-including women, youth, transport operators, labor unions, employers, artisans, the physically challenged, and minority groups — participate meaningfully and benefit from the growth and transformation opportunities of the CFTA. ${ }^{637}$ The final cause of the CFTA must be the welfare of citizens, millions of whom still struggle daily for survival in an insupportable environment. Any rule or policy that misses this end cannot justify its existence. Good intentions alone are not enough, because humanity is not abstract. The concept of Pan-Africanism implicates one citizenship. The point of African unity should not be in mere rhetoric, but in "the practical need to work together to realise concrete improvements in the well-being and security of our citizens which would be unattainable working as individual entities." 638 The neglect of a people at the foot of a society's ladder indicts failed policies and leadership, both at national and regional levels. Such neglect will make it difficult for

635. See Decision on Operational Phase, supra note 552, para. 14 (calling upon members to assume these obligations).

636. AU Act, supra note 14, art. 3(i).

637. Cf. Malabo Declaration, supra note 255, pmbl. (resolving to ensure that all population segments participate and benefit from growth and transformation opportunities).

638. Kagame Report, supra note 228, at 3 (emphasis added). 
protagonists of an African Renaissance to gain traction among the many skeptical citizens, let alone critics. 